\title{
SELECTION FOR OVULATION RATE IN RABBITS
}

\author{
Patricia Laborda Vidal
}

This Thesis has been submitted in fulfilment of the requirements for the degree of Doctor at the Universidad Politécnica de Valencia.

Esta tesis ha sido escrita y presentada como uno de los requisitos para optar al grado de Doctor con Mención Europea por la Universidad Politécnica de Valencia.

Valencia, $28^{\text {th }}$ November 2011 
Thesis supervisors

Dra. Mạ Antonia Santacreu Jerez

Instituto de Ciencia y Tecnología Animal

Universidad Politécnica de Valencia

Dra. Mạ Lorena Mocé Cervera

Departamento de Producción Animal y Ciencia y Tecnología de los Alimentos.

Universidad Cardenal Herrera-CEU, Valencia 
Live every day as if it where your last. Live every day as if you would live forever.

Albert B. Sabin 



\section{ACKNOWLEDGEMENTS}

Después de 5 años de trabajo, "Selection for ovulation rate in rabbits" ha salido a la luz. Durante este tiempo he disfrutado de buenos momentos, de momentos duros, y de momentos inolvidables. Me gustaría agradecer a todas las personas que de algún modo han colaborado en mi trabajo. A todas ellas, gracias!

A mi familia: mis Padres, por ser mi guía y mi impulso para conseguir nuevos retos; por vuestro apoyo incondicional y vuestro cariño, porque gracias a vosotros estoy hoy aquí. A mi Teta, por enseñarme siempre con tu ejemplo, y por prestarme siempre tu ayuda. A BebeZoe, mi regalo sorpresa de las Navidades de 2009, por ser el mejor regalo que me podían hacer. A lan, por contribuir a mi regalo. No puedo dejar de mencionar en estos agradecimientos a Pico (mi galguito fiel que me hace reír) porque si lo hiciera, no sería yo.

A Vic, por tu amor y tu comprensión; por compartir tus ilusiones conmigo; por saber sacarme una sonrisa siempre; por el día en que salvaste todos mis apuntes del suicidio. Además, por haber dedicado parte de nuestro tiempo de pajareo a esta tesis y por ayudarme con el formato de la tesis.

A Monfragüe, mi pequeño paraíso. Gracias por llevarnos, Johnny y Edu, y gracias por esas semanas inolvidables.

A mis 101 Dálmatas de Veterinaria, que no los puedo nombrar a todos, porque son 101;-) Amigos junto a los que he pasado tantos buenos momentos y que siempre han estado cerca de mí. Ánimo, Eva y Alo, que ya os queda poco a vosotras también! A mis amigas del cole: Mauri, Bea, Elvi, Salo y Dra. Mache, por una amistad que nos ha visto crecer i27 años juntas!

A Deivid, Rosa, Bea, lla, por empezar nuestra amistad en el grupo de comidas. En especial a: Rosa, por apadrinarme a mi llegada al ICTA, y por echarme siempre una mano. Deivid, por estar siempre pendiente, por tus incansables intentos de llevarnos a bucear, por esas cervezas que te debo... Bea, por tu apoyo de hermana pequeña, porque nos hemos desarrollado juntas en el camino del doctorado... y por esa futura celebración de tesis juntas!

A los pequeños acuicultores: Mamen, Fer, Pablito, Rosa, Paulo; y a las supernenas del 5o: Mara, Estrella y Carmen. Por todas las risas que nos hemos echado juntos, por el UPV open de padel mixto 2011 y por todas las actividades extraescolares de estos años, de las cuales me he pelado algunas muy a mi pesar, pero espero poder recuperarlas! En especial a Lobster, por nuestro futuro juntas en Teclas! A Vicen, por endulzarnos los días... 
A Noe, Javi R. y Fede, compañeros y amigos. Cuánto me he reído con vosotros: Noe, una persona alegre y de gran corazón. Javi... qué sería del mundo sin tu toque de humor! Fede, una persona entregada y responsable en su trabajo; gracias por haberte encargado de nuestr@s conej@s, y por esas mañanas de los lunes escuchando "No somos nadie".

A todos mis compañeros de la 4a planta, en especial a Cris, Vero y Mohamed, por compartir nuestras alegrías, nuestros problemas y nuestras dudas. A otras personas con las que compartí vivencias en la 4a planta y fuera de ella: imponentes Marcia y Maneco; Celia, por todo tu cariño, y Mariam, por reírte de las pequeñas cosas.

Gracias a mis directoras de Tesis, Toñi y Lore, por haber sacado este proyecto adelante, por vuestras sugerencias e ideas y por vuestro esfuerzo. Gracias, Lore porque, a pesar de todas las pruebas que has tenido que superar estos 2 últimos años, no has dejado de ayudarme en todo lo que estaba en tus manos.

A Agustín, por las largas reuniones que han ayudado a mejorar mi trabajo y por aportar tu punto de vista. A los demás compañeros que han aportado su granito de arena a mi Tesis: Manolo y Pilar (por compartir vuestros conocimientos); Jose, Raquel, Paco y Lola (por vuestras aportaciones en la parte de reproducción) y Javi M. (por tu valiosa ayuda en HPLC).

Mi estancia en el ABG de Wageningen en 2009 fue enriquecedora: también a ellos les quiero agradecer el haber llegado hasta aquí. A Juanma, Filippo, Laurie y Enrique, por esas veladas de canciones y guitarra, inolvidables (hasta para nuestros vecinos) y por esas fantásticas pizza parties. Thanks to John Baastiansen, for his wonderful way of explaining something almost unintelligible and for having always time for me. Thanks to Johan van Arendonk, a great boss in every sense, with an interesting point of view. I had a wonderful time at Zodiac. Of course, thanks to the Zodiak volleyball team matches, for being the best thing of Mondays.

A mis compañeros del UCH-CEU, Veterinaria, sobre todo a la Unidad de Diagnóstico por Imagen, con quienes he compartido este último año. Gracias también a Joaquín por su apoyo, y a Joaq, por sus ánimos, y por esas tardes de volley-playa y esas risas. 


\section{TABLE OF CONTENTS}

$\begin{array}{ll}\text { ABSTRACT } & 1\end{array}$

$\begin{array}{ll}\text { RESUMEN } & 3\end{array}$

$\begin{array}{ll}\text { RESUM } & 5\end{array}$

$\begin{array}{lll}\text { Chapter } 1 & \text { GENERAL INTRODUCTION } & 7\end{array}$

1. General introduction to rabbit production 9

$\begin{array}{ll}\text { 2. Litter size and its components } & \mathbf{1 1}\end{array}$

$\begin{array}{ll}2.1 \text { Ovulation rate } & 12\end{array}$

2.1.1 The process of ovulation

2.1.2 Oocyte quality

2.1.3 Ovulatory timing

2.1.4 Estimation of ovulation rate

2.2 Prenatal survival

2.2.1 Embryonic and fetal survival

2.2.2 Estimation of embryonic and fetal survival

3. Selection for litter size

3.1 Conventional selection for litter size

3.2 Selection for hyperprolific lines

4. Selection for the components of litter size

4.1 Selection for ovulation rate

4.2 Selection for prenatal survival

4.3 Selection for uterine capacity

4.4 Selection for prenatal survival and ovulation rate

4.5 Two-step selection for ovulation rate and litter size 
CHAPTER 3 Selection for ovulation rate in rabbits: genetic parameters, direct response and correlated response on litter size.

CHAPTER 4 Selection for ovulation rate in rabbits: genetic parameters and correlated responses on survival rates.

CHAPTER 5 Selection for ovulation rate in rabbits: direct and correlated responses estimated with a cryopreserved control population.

1. Experiments of selection for litter size and its components

1.1 Selection for ovulation rate and its correlated response in litter size

1.2 Selection for litter size and its correlated response in ovulation rate

2. Physiological causes for the lacking correlated response in litter size

2.1 Oocyte maturation

2.2 Variability in embryonic development

2.3 Uterine crowding

3. Other selection possibilities 


\section{INDEX OF TABLES}

Table 1.1: Direct responses in number of kits born alive (NBA) or number of

kits weaned (NW) and correlated responses in ovulation rate (OR) and prenatal survival (PS) estimated per generation in rabbits, with their standard errors (in parenthesis).

Table 1.2a: Estimated heritabilities $\left(\mathrm{h}^{2}\right)$ of ovulation rate $(\mathrm{OR})$ and prenatal survival (PS) and phenotypic and genetic correlations ( $r_{p}$ and $r_{g}$, respectively) between these traits and litter size (LS) at the day of gestation indicated (DG) in mice, pigs and rabbits.

Table 1.2b: Estimated heritabilities $\left(\mathrm{h}^{2}\right)$ of ovulation rate $(\mathrm{OR})$ and prenatal survival (PS) and phenotypic and genetic correlations ( $r_{p}$ and $r_{g}$, respectively) between these traits and litter size (LS) at the day of gestation indicated (DG) in mice, pigs and rabbits.

Table 1.3: Direct response in ovulation rate $(\mathrm{OR})$ and correlated responses in total number born (TNB) and prenatal survival (PS) with their standard errors (SE) estimated per generation in the experiments of selection for OR in mice and pigs.

Table 1.4: Responses in prenatal survival (PS), ovulation rate (OR) and litter size (LS) estimated per generation in pigs and mice selected for prenatal survival with their standard errors (in parenthesis).

Table 1.5: Responses to selection to increase uterine capacity (UC) and correlated responses in ovulation rate (OR), litter size (LS) and prenatal survival (PS) estimated per generation.

Table 1.6: Responses to selection in ovulation rate (OR), litter size (LS) and prenatal survival (PS) estimated per generation in pigs and mice selected for an index of ovulation rate and prenatal survival, with their standard errors (in parenthesis).

Chapter 3, Table 1: Means and SD (in parenthesis) for ovulation rate at second gestation (OR2), ovulation rate at the last gestation (ORS), ovulation rate (OR), 
right ovulation rate (ROR), left ovulation rate (LOR), ovulatory difference (OD), litter size (LS) and number of kits born alive (NBA) in generations 0 to 10 .

Chapter 3, Table 2: Features of the marginal posterior distributions of the heritability for ovulation rate at second gestation (OR2), ovulation rate at the last gestation (ORS), ovulation rate (OR), right ovulation rate (ROR), left ovulation rate (LOR), ovulatory difference (OD), litter size (LS) and number of kits born alive (NBA).

Chapter 3, Table 3: Features of the marginal posterior distributions of the phenotypic correlations between the traits analyzed: ovulation rate at second gestation (OR2), ovulation rate at the last gestation (ORS), ovulation rate (OR), right ovulation rate (ROR), left ovulation rate (LOR), ovulatory difference (OD), litter size (LS) and number of kits born alive (NBA).

Chapter 3, Table 4: Features of the marginal posterior distributions of the genetic correlations between the traits analyzed: ovulation rate at second gestation (OR2), ovulation rate at the last gestation (ORS), ovulation rate (OR), right ovulation rate (ROR), left ovulation rate (LOR), ovulatory difference (OD), litter size (LS) and number of kits born alive (NBA).

Chapter 4, Table 1: Means and SD for number of implanted embryos (IE), number of implanted embryos on the right and on the left uterine horn (RIE and LIE), implantatory difference (ID=|RIE-LIE $\mid$ ), embryonic survival (ES), fetal survival (FS) and prenatal survival (PS) in the base generation.

Chapter 4, Table 2: Features of the marginal posterior distributions of the heritability $\left(\mathrm{h}^{2}\right)$ and the repeatability (r) of number of implanted embryos (IE), number of implanted embryos on the right and on the left uterine horn (RIE and LIE), implantatory difference (ID=|RIE-LIE $\mid$ ), and embryonic survival (ES) and the heritability of fetal survival (FS) and prenatal survival (PS).

Chapter 4, Table 3: Features of the marginal posterior distributions of the phenotypic correlation between the traits analyzed: ovulation rate (OR), ovulatory difference (OD), number of implanted embryos (IE), number of implanted embryos on the right and on the left uterine horn (RIE and LIE), 
implantatory difference (ID=|RIE-LIE $\mid$ ), embryonic survival (ES), fetal survival (FS) and prenatal survival (PS).

Chapter 4, Table 4: Features of the marginal posterior distributions of the phenotypic correlation between the traits analyzed: litter size (LS), number of implanted embryos (IE), implantatory difference (ID=|RIE-LIE $\mid$ ), embryonic survival (ES), fetal survival (FS) and prenatal survival (PS).

Chapter 4, Table 5: Features of the marginal posterior distributions of the genetic correlation between the traits analyzed: ovulation rate (OR), number of implanted embryos (IE), number of implanted embryos on the right and on the left uterine horn (RIE and LIE), implantatory difference (ID=|RIE-LIE $\mid$ ), embryonic survival (ES), fetal survival (FS) and prenatal survival (PS).

Chapter 4, Table 6: Features of the marginal posterior distributions of the genetic correlation between the traits analyzed: litter size (LS), number of implanted embryos (IE), implantatory difference (ID=|RIE-LIE $\mid$ ), embryonic survival (ES), fetal survival (FS) and prenatal survival (PS).

Chapter 5, Table 1: Number of records used to analyze the traits ovulation rate $(\mathrm{OR})$, right and left ovulation rate (ROR and LOR), ovulatory difference $(\mathrm{OD}=$ |ROR-LOR $\mid$ ), litter size (LS), number of kits born alive (NBA), number of kits weaned (NW), number of implanted embryos (IE), right and left implanted embryos (RIE and LIE), implantatory difference (ID=|RIE-LIE $\mid$ ), embryonic survival (ES), fetal survival (FS), prenatal survival (PS) and weight at second gestation (WOR) in the selected and the control line.

Chapter 5, Table 2: Means, SD, standard errors (SE), coefficients of variation $(\mathrm{CV})$ and units of ovulation rate (OR), right and left ovulation rate (ROR and LOR), litter size (LS), number of kits born alive (NBA), number of kits weaned (NW), number of implanted embryos (IE), right and left implanted embryos (RIE and LIE), ovulatory difference $(\mathrm{OD}=|\mathrm{ROR}-\mathrm{LOR}|)$, implantatory difference (ID=|RIE-LIE $\mid$ ), embryonic survival (ES), fetal survival (FS), prenatal survival (PS) and adult weight at second gestation (WOR) in the control line. 
Chapter 5, Table 3: Features of the estimated marginal posterior distributions of the differences between the selected and the control line for ovulation rate (OR), right and left ovulation rate (ROR and LOR), ovulatory difference (OD=|ROR$\mathrm{LOR} \mid$ ) and weight at second gestation (WOR).

Chapter 5, Table 4: Features of the estimated marginal posterior distributions of the differences between the selected and the control line for the number of implanted embryos (IE), right and left implanted embryos (RIE and LIE) and implantatory difference (ID=|RIE-LIE $\mid$ ).

Chapter 5, Table 5: Features of the estimated marginal posterior distributions of the differences between the selected and the control line for embryonic survival (ES), fetal survival (FS) and prenatal survival (PS).

Chapter 5, Table 6: Features of the estimated marginal posterior distributions of the differences between the selected and the control line for litter size (LS), number of kits born alive (NBA) and number of kits weaned (NW). 


\section{INDEX OF FIGURES}

Figure 1.1: Rabbit carcass meat production in Europe in 2010.

Figure 1.2 Rabbit census in Spain in 2010.

Figure 1.3: Rabbit carcass meat production in Spain in 2010.

Figure 1.4: Meat consumption in Spain in 2001.

Chapter 3, Figure 1: Genetic trends for ovulation rate (OR), litter size (LS) and number of kits born alive (NBA).

Chapter 3, Figure 2: Genetic trends for ovulation rate (OR), right ovulation rate (ROR), left ovulation rate (LOR) and ovulatory difference (OD).

Chapter 4, Figure 1: Genetic trends for number of implanted embryos (IE), right and left implanted embryos (RIE and LIE) and implantatory difference $(\mathrm{ID}=|\mathrm{RIE}-\mathrm{LIE}|)$.

Chapter 4, Figure 2: Genetic trends for embryonic survival (ES), fetal survival (FS) and prenatal survival (PS). 



\section{ABSTRACT}

The aim of this Thesis was to estimate the direct response and the correlated responses in litter size and survival rates in an experiment of selection for ovulation rate in rabbits.

Selection for ovulation rate was performed in a rabbit line during 10 generations. Selection was based on the phenotypic value of ovulation rate estimated at $d 12$ of second gestation by laparoscopy. A control line was produced recovering embryos from 50 donor females and 18 males, belonging to the base generation of the line selected for ovulation rate. Approximately 470 embryos were vitrified and stored in liquid $\mathrm{N}_{2}$ until transfer at the end of the selection experiment $\left(10^{\text {th }}\right.$ generation of the selected line).

Traits recorded were: litter size (LS), estimated as total number of rabbits born per litter in up to five parities; ovulation rate (OR), estimated as the number of corpora lutea in both ovaries; right and the left ovulation rates (ROR and LOR); the number of implanted embryos (IE), estimated as the number of implantation sites; the number of right and left implanted embryos (RIE and LIE); ovulatory difference (OD), defined as the difference between ROR and LOR, expressed as an absolute value; implantatory difference (ID), defined as the difference between RIE and LIE, expressed as an absolute value; embryonic survival (ES), calculated as IE/OR; fetal survival (FS), calculated as LS/IE; prenatal survival (PS), calculated as LS/OR.

Bayesian methodology was used to analyze the data. The estimated heritabilities of OR, LS, ES, FS and PS were 0.16, 0.09, 0.09, 0.24 and 0.14, respectively. The estimated phenotypic correlations of OR with LS, ES, FS and PS were $0.09,-0.07,-0.26$ and -0.28 , respectively. The genetic correlation of OR with LS and ES were estimated with low accuracy and nothing can be said about their sign. The estimated genetic correlations of OR with FS and PS were negative (probability of being negative 1.00 and 0.98 , respectively). The estimated phenotypic and genetic correlations between LS and survival rates were positive (probability of being positive of 1.00 ).

Responses to selection were estimated by two methods, genetic trends and differences between the selected and the control line, both estimates being similar for 
most of the traits. Ovulation rate increased with selection (1.3 ova in 10 generations estimated with genetic trends; 2.1 ova in 10 generations estimated with the control line), but there was no correlated response in litter size, supporting that the genetic correlation between ovulation rate and litter size should be close to zero. No clear changes were observed in ovulatory difference and implantatory difference. A small decrease in embryonic survival expressed as a percentage (around 5\% in 10 generations) was observed when comparing the selected and the control lines, but this reduction was not estimated with genetic trends. A decrease in fetal survival expressed as a percentage (around $10 \%$ in 10 generations) seemed to be the main responsible for the lack of correlated response observed in litter size. 


\section{RESUMEN}

El objetivo de esta tesis ha sido estudiar la respuesta directa a la selección por tasa de ovulación en conejo y las respuestas correlacionadas en tamaño de camada y tasas de supervivencia.

Los animales pertenecían a una línea de conejos seleccionada por tasa de ovulación durante 10 generaciones. La selección se realizó en base al valor fenotípico de la hembra, que se midió el día 12 de la segunda gestación mediante laparoscopia. Se creó una línea control a partir de la recuperación de aproximadamente 470 embriones de 50 hembras donantes de la generación base. Los embriones fueron vitrificados y almacenados en nitrógeno líquido hasta su transferencia al final del experimento de selección (generación 10 de la línea seleccionada).

Se midieron los siguientes caracteres: tamaño de camada (LS), estimada como el número total de gazapos al parto en un máximo de 5 partos; tasa de ovulación (OR), estimada como el número de cuerpos lúteos en los dos ovarios; tasa de ovulación derecha y tasa de ovulación izquierda (ROR y LOR); el número de embriones implantados totales (IE), en el lado derecho (RIE) y en el lado izquierdo (LIE); la diferencia ovulatoria (OD), definida como la diferencia entre ROR y LOR, expresada en valor absoluto; la diferencia de implantación (ID), definida como la diferencia entre RIE y LIE, expresada en valor absoluto; la supervivencia embrionaria (ES), calculada como IE/OR; la supervivencia fetal (FS), calculada como LS/IE; la supervivencia prenatal (PS), calculada como LS/OR.

Se utilizó metodología bayesiana para analizar los datos. Las estimas de las heredabilidades de OR, LS, ES, FS y PS fueron 0.16, 0.09, 0.09, 0.24 y 0.14, respectivamente. Las estimas de las correlaciones fenotípicas de OR con LS, ES, FS y PS fueron $0.09,-0.07,-0.26$ and -0.28 , respectivamente. Las estimas de las correlaciones genéticas de OR con LS y ES tuvieron una baja precisión, y no se pudo concretar su signo. Las estimas de las correlaciones genéticas de OR con FS y PS fueron negativas (probabilidad de ser negativa de 1.00 y 0.98 , respectivamente). Las correlaciones fenotípicas y genéticas entre LS y las tasas de supervivencias fueron positivas (probabilidad de ser positivas de 1.00). 
La respuesta a la selección se estimó por dos métodos, tendencias genéticas y diferencias entre la línea seleccionada y la línea control, siendo ambas estimas similares para la mayoría de los caracteres. La selección aumentó la tasa de ovulación: la estima de la tendencia genética para la tasa de ovulación fue de 1.3 óvulos en 10 generaciones y la respuesta estimada con la población control fue de 2.1 óvulos en 10 generaciones. Sin embargo, no se produjo respuesta correlacionada en tamaño de camada, lo que apoyó una correlación cercana a cero entre tasa de ovulación y tamaño de camada. Las respuestas observadas en diferencia ovulatoria y diferencia de implantación no fueron concluyentes. Se produjo una ligera reducción de la supervivencia embrionaria expresada en porcentaje (alrededor de 5\% en 10 generaciones) al estimar la respuesta con la línea control; este descenso no se observó en la estima de la tendencia genética. La disminución de la supervivencia fetal expresada en porcentaje (aproximadamente $10 \%$ en 10 generaciones) pareció ser la principal responsable de la ausencia de respuesta correlacionada en tamaño de camada en el experimento de selección por tasa de ovulación. 


\section{RESUM}

L'objectiu d'aquesta tesi ha sigut estudiar la resposta directa a la selecció per tasa d'ovulació en conill i les respostes correlacionades en tamany de la ventrada, embrions implantats i tases de supervivència.

Els animals pertanyien a una línia de conills seleccionada per tasa d'ovulació durant 10 generacions. La selecció es va realitzar sobre la base del valor fenotípic de la femella, que es va mesurar el dia 12 de la segona gestació mitjançant laparoscòpia. Es va crear una línia control a partir de la recuperació d'aproximadament 470 embrions de 50 femelles donants de la generació base. Els embrions van ser vitrificats i emmagatzemats en nitrogen líquid fins a la seva transferència, al final de l'experiment de selecció (generació 10 de la línia seleccionada).

Es van mesurar els següents caràcters: tamany de la ventrada (LS), estimada com el nombre total de llorigós al part en fins a 5 parts; tasa d'ovulació (OR), estimada com el nombre de cossos lutis en els dos ovaris; tasa d'ovulació dreta i tasa d'ovulació esquerra (ROR i LOR), el nombre d'embrions implantats totals (IE), al costat dret (RIE) i al costat esquerre (LIE), la diferència ovulatòria $(O D)$, definida com la diferència entre ROR i LOR, expressada en valor absolut, la diferència d'implantació (ID), definida com la diferència entre RIE i LIE, expressada en valor absolut, la supervivència embrionària (ES), calculada com IE/OR, la supervivència fetal (FS), calculada com LS/IE, la supervivència prenatal (PS), calculada com LS/OR.

Es va utilitzar metodologia bayesiana per analitzar les dades. Les estimes de les heretabilitat d'OR, LS, ES, FS i PS van ser 0,16, 0,09, 0,09, 0,24 i 0,14, respectivament. Les estimes de les correlacions fenotípiques d'OR amb LS, ES, FS i PS van ser 0,09, $0.07,-0.26$ and -0.28 , respectivament. Les estimes de les correlacions genètiques d'OR amb LS i ES van tenir una baixa precisió, i no es va poder concretar el seu signe. Les estimes de les correlacions genètiques d'OR amb FS i PS van ser negatives (probabilitat de ser negativa de 1.00 i 0,98, respectivament). Les correlacions fenotípiques i genètiques entre LS i les tases de supervivències van ser positives (probabilitat de ser positives de 1.00). 
La resposta a la selecció es va estimar per dos mètodes, tendències genètiques i diferències entre la línia seleccionada i la línia control, sent ambdues estimes similars per a la majoria dels caràcters. La selecció va augmentar la tasa d'ovulació (1.3 òvuls en 10 generacions mitjançant les estimes de tendències genètiques; 2.1 òvuls en 10 generacions estimada com la diferència entre les línies seleccionada i control), però no es va produir resposta correlacionada en el tamany de la ventrada, la qual cosa va recolzar una correlació propera a zero entre tasa d'ovulació i el tamany de la ventrada. Les respostes observades en diferència ovulatòria i diferència d'implantació no van ser concloents. Es va produir una lleugera reducció de la supervivència embrionària expressada en percentatge (al voltant de $5 \%$ en 10 generacions) al estimar la resposta amb la línia control; aquest descens no es va observar en l'estima de la tendència genètica. La disminució de la supervivència fetal expressada en percentatge (aproximadament $10 \%$ en 10 generacions) va semblar ser la principal responsable de l'absència de resposta correlacionada en tamany de la ventrada en l'experiment de selecció per tasa d'ovulació. 


\title{
Chapter 1
}

\section{General introduction}

\author{
P. Laborda
}

Instituto de Ciencia y Tecnología Animal, Universidad Politécnica de Valencia, 46071 Valencia. Spain. 



\section{General introduction to rabbit production}

Global meat production is around 285 million tonnes (FAO, Food and Agriculture Organization, 2011) and rabbit carcass meat production is near 1.2 million tonnes ( $0.4 \%$ of the global meat production), which corresponds approximately 857 million rabbits (Eady, 2008). The majority is produced in Europe (50\%) while Asia (predominantly China) produces 41\%. In 2010, the main European producers were located in Italy (39\%), France (27\%) and Spain (19\%) (Figure 1.1). These three European countries produce rabbits mainly under intensive farming conditions, although there still does exist a significant level of home production (REGA, Registro General de Explotaciones Ganaderas, 2010).

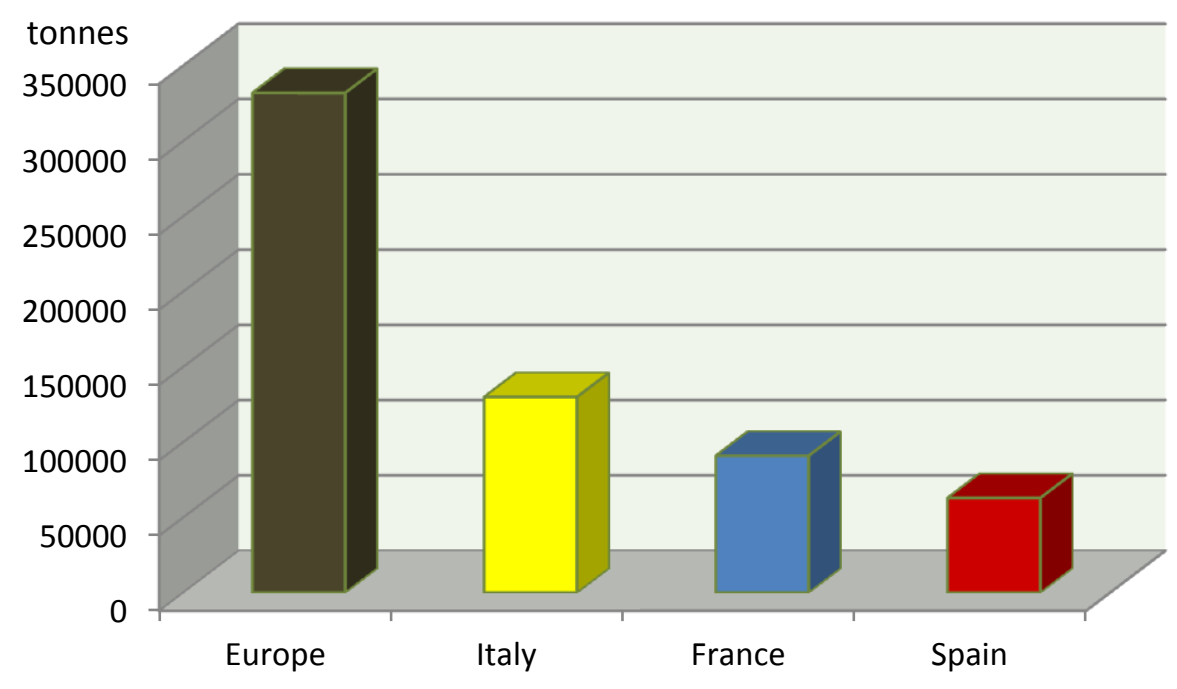

Figure 1.1: Rabbit carcass meat production in Europe in 2010. Developed from:

http://www.marm.es/app/vocwai/documentos/Adjuntos AreaPublica/INDICADORES\%20ECO N\%C3\%93MICOS\%20SECTOR\%20CUN\%C3\%8DCOLA\%202010.pdf

In Spain, Cataluña stands out as the main producer (30\%). Data from 2010 show that a high proportion of the rabbits censed in Spain (near 80\%) is concentrated in only 5 communities: Cataluña (1.840.394), Castilla y León (988.866), Galicia (823.898), Comunidad Valenciana (653.663) and Castilla La Mancha (537.321), while rabbit carcasse meat is mainly produced in Cataluña (19.778), Galicia (11.836), Aragón 
(8.549), Castilla y León (8105) and Comunidad Valenciana (5067) (Figures 1.2 and 1.3; REGA, Registro General de Explotaciones Ganaderas).
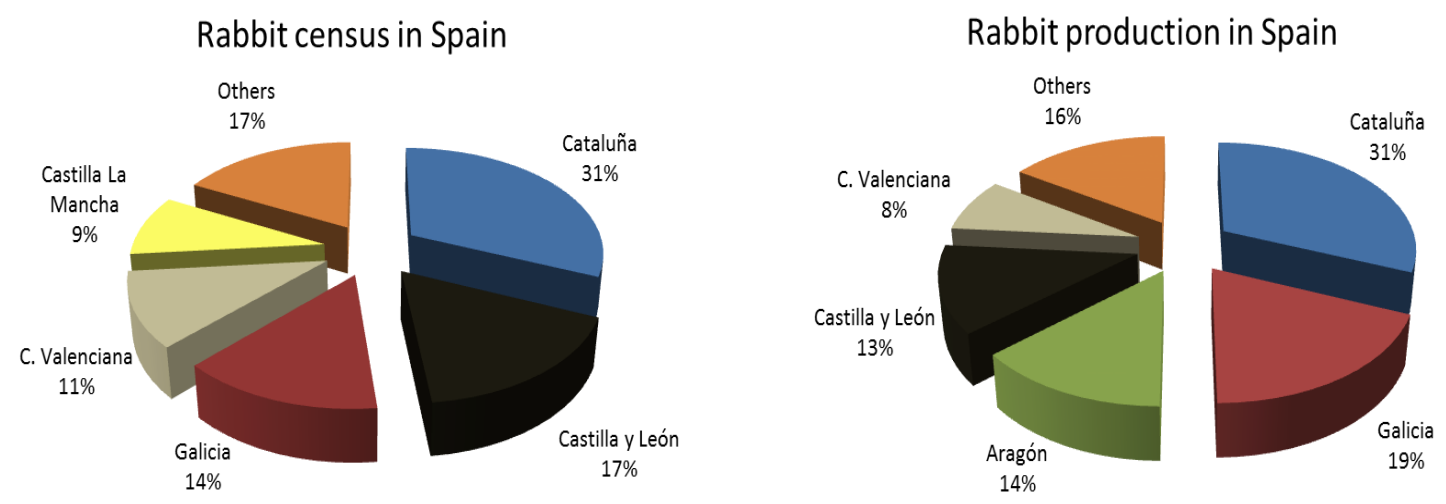

Figures 1.2 and 1.3. Rabbit census and rabbit carcass meat production in Spain in 2010. Developed from:

http://www.marm.es/app/vocwai/documentos/Adjuntos AreaPublica/INDICADORES\%20ECO N\%C3\%93MICOS\%20SECTOR\%20CUN\%C3\%8DCOLA\%202010.pdf

Rabbit consumption is stable or slightly decreasing in the European countries. In Spain, only $5 \%$ of the meat consumed is rabbit (Figure 1.4, INRA SAGA). Efforts are underway to increase the consumer appeal of rabbit meat by introducing "quick cook" meals and a variety of cuts of meat, rather than rely on the traditional whole carcass presentation (including heads) (Eady, 2008).

\section{Meat consumption in Spain (kg/person; \%)}

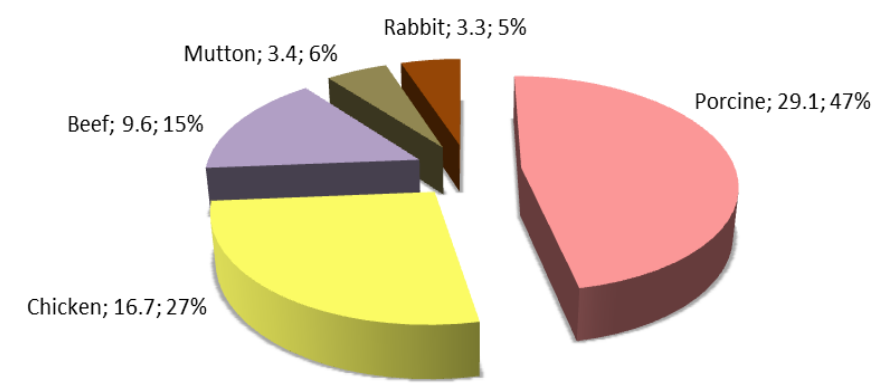

Figure 1.4. Meat consumption in Spain in 2001 (kg/person; \%). Developed from:

http://www.avicampus.fr/PDF/PDFlapin/selectionlapin1.pdf 
In rabbit production, a high proportion of the total costs correspond to feeding $(60 \%$; Pascual et al., 2011). Feeding costs can be reduced through an improvement in the conversion rate. Fixed costs (30\%; Pascual et al., 2011) can be reduced by increasing female productivity, because costs can be distributed among a higher number of animals. Therefore, breeding programs in rabbits include growth rate and reproductive efficiency as the most important aspects.

The genetic improvement programmes in rabbits are organized in a pyramidal structure with three levels: nucleus populations on the top of the pyramid, multipliers and commercial farms on the bottom. In most nucleus populations, selection is performed on three specialized rabbit lines, two maternal lines, selected to increase litter size and a paternal line, selected for growth rate. In the multipliers, animals from both maternal lines are mated to obtain hybrids. Hybrid females present heterosis in reproductive traits, which leads to higher litter sizes in hybrid females than in "pure" females. Therefore, three way crosses are usually carried out. Finally, in the commercial farms, hybrid females are mated to males from the paternal line, and the final product is sent to slaughterhouse.

\section{Litter size and its components}

The increase in litter size is the main objective in selection experiments in maternal rabbit lines (reviewed by Khalil and Al-Saef, 2008). Litter size can be measured at birth, at weaning or at slaughter. The disadvantage of measuring litter size at weaning or at slaughter is that these traits depend on survival rate after birth, which depends as well on many environmental effects. Therefore, their heritabilities might be lower than that of litter size at birth. However, the trait considered in most selection experiments in rabbits is litter size at weaning, because it represents both the prolificacy and the maternal performance of the female (reviewed by Mocé and Santacreu, 2010). In rabbits, litter size at weaning is highly correlated with litter size at birth $0.74(0.04)$ in García and Baselga 2002a; 0.80 (0.03) in Ragab and Baselga, 2011; 0.85 (0.07) in our experiment, data not shown). 
Litter size at birth in polytocous species is mainly determined by two parameters: number of ova shed per estrus and proportion of these ova represented by normal fetuses at birth, also called prenatal survival. Fertilization rate is usually high in rabbits (Adams, 1960a; Torrès et al., 1984; Santacreu et al., 1990; Theau-Clement et al., 2009), pigs (Bazer et al., 1988; Soede et al., 1995; Geisert and Schmitt, 2002) and mice (Joakimsen and Baker, 1977; Wilmut et al., 1986) and is therefore not considered as a cause of variation of litter size.

\subsection{Ovulation rate}

\subsubsection{The process of ovulation}

Ovulation rate is the total number of ova shed by the ovaries at ovulation. In rabbits, ovulation is induced by the coitus stimulus. The coitus leads to a nervous stimulus that induces release of the gonadotropin-releasing hormone $(\mathrm{GnRH})$ in the hypothalamous. This hormone activates the synthesis and secretion of the follicle-stimulating hormone (FSH) and the luteinizing hormone (LH) at the anterior pituitary gland. The FSH is known to be very important for the terminal growth of the follicles, while an acute rise in LH triggers ovulation (Rosell, 2000). Follicular development can determine the degree of the oocyte maturation (oocyte quality) and the ovulatory timing. Both factors can affect posterior embryonic and fetal development. To our knowledge, there is only one study reporting the relationship between oocyte quality and ovulation rate (Koenig et al., 1986). In this study in pigs, a higher proportion of immature oocytes was found in females selected for ovulation rate and in superovulated females compared to unselected females and to naturally ovulated ones, respectively. No study has been found relating the ovulatory timing and ovulation rate.

\subsubsection{Oocyte quality}

Oocyte quality, or developmental competence, is acquired during folliculogenesis as the oocyte grows and during the period of oocyte maturation (Krisher, 2004). Both nuclear and cytoplasmic maturation have to be completed successfully to be a 
competent oocyte. Oocyte quality affects the establishment and maintenance of pregnancy modifying early embryonic survival and fetal development (Krisher, 2004).

Multiple methods have been proposed to assess oocyte quality. The best method is to evaluate the fertilization ability of classified oocytes and their developmental competence along gestation following embryo transfer. However, this is usually not possible because of economic and technical factors. The study of oocyte morphology is relatively quick and simple; however, it is unreliable if it is not accompanied by other methods (Balaban and Urman, 2006). Other methods to assess oocyte quality that have been proposed are: measurement of ATP, an important energy source for maintaining protein synthesis and other cellular functions (reviewed by Krisher, 2004); measurement of glutathione (GSH), the main compound that protects the cell against the oxidative stress (reviewed by Luberda, 2005; Rausell and Tarín, 2005); quantification of mitochondrial DNA; quantification of oocyte mRNA and proteins (reviewed by Krisher, 2004). Besides, some authors have studied the expression of genes in the granulosa cells or in the oocyte itself, looking for specific molecular markers of oocyte quality, or have performed polar body biopsy to screen oocytes with chromosomal abnormalities deriving from errors in the two meiotic divisions (reviewed by Revelli et al., 2009).

\subsubsection{Ovulatory timing}

Approximately $8 \mathrm{~h}$ post-coitum (p.c.), the ovulatory follicles begin to release the oocytes. Most of the follicles ovulate simultaneously in a short period of time, with a small proportion of them ovulating later (Fujimoto et al., 1974 in rabbits). Ovulation is completed in rabbits $14 \mathrm{~h}$ p.c. (Fujimoto et al., 1974). Late ovulating oocytes may be fertilized later, leading to lesser developed embryos. The more developed embryos advance the uterine secretions (Torres et al., 1984 in rabbits; Pope, 1988 and Xie at al., 1990 in pigs; Wilmut et al., 1986 and Al-Shorepy et al., 1992 in mice). The lesser developed embryos may not tolerate the degree of asynchrony associated with the advanced uterine environment, and they may die during the embryonic or the fetal period (Peiró et al., 2007 in rabbits; Wilde et al., 1988 and Pope et al., 1990 in pigs). Synchrony between the developing embryos and the secretions of the uterus has been 
recognized as a critical factor to maintain a successful pregnancy (reviewed by Pope, 1988 and Barnes, 2000).

\subsubsection{Estimation of ovulation rate}

In rabbits, ovulation rate is usually estimated as the number of corpora lutea in both ovaries, counted in vivo by laparoscopy or post mortem after dissection of the ovary. Both measurements of ovulation rate have shown to have a high regression coefficient (0.91; Santacreu et al., 1990). This indicates that laparoscopy is a very accurate technique to measure ovulation rate at $\mathrm{d} 12$ of gestation.

\subsection{Prenatal survival}

\subsubsection{Embryonic and fetal survival}

Prenatal survival is the proportion of ova represented by neonates. It comprises two periods: the embryonic and the fetal period. In rabbits, it has been accepted to call embryonic period to the period before implantation ( $d$ 7) and fetal period to the period from implantation until birth (d 30) (Mocé et al., 2010).

Prenatal mortality is around 30\% in rabbits (Adams, 1960a,b; García and Baselga, 2002), $10-14 \%$ corresponding to the embryonic period, and $20-22 \%$ to the fetal period. Prenatal mortality in mice is lower, around $20 \%$. This percentage is almost equally distributed between the pre- and the postimplantation period (reviewed by Wilmut et al., 1986). In pigs, a prenatal loss of 40 to $60 \%$ has been reported (reviewed by Foxcroft at al., 2006); the largest proportion of it occurs before d 30-35 of gestation of the 114day gestation period.

In rabbits, the nutrition of the embryo relies first upon the yolk sac. The visceral yolk sac appears on day nine, and on $d 13$ it is overlapped on the endometrium. A chorioallantoic placenta begins its development at $d 8$ of gestation, but its characteristics are not fully developed until about d 12 (Carney et al., 2004). The transition between both placentation types engenders a critical period for the fetus. In rabbits, most of the fetal mortality (66\%) occurs between d 8 and 17 of gestation (Adams 1960a,b), coinciding with the formation of the chorioallantoic placenta (Hafez and Tsutsumi, 1966; Carney et al., 2004). There is a second mortality peak in rabbits 
occurring between $\mathrm{d} 18$ and 23 of gestation, which coincides with the final phase of uterine enlargement (Reynolds, 1946 cited by Adams 1960a,b). The blood circulation of the endometrium plays an important role in embryonic survival and fetal development (Hafez and Tsutsumi, 1966), because rabbits, as mice, develop hemochorial placentas. In hemochorial placentas, the fetal vascular endothelium is in direct contact with the maternal blood (reviewed by Leiser and Kaufmann, 1994). Therefore, fetal development depends on the number of vessels arriving at the implantation site (Duncan, 1969; Argente et al., 2003; Mocé et al., 2004 in rabbits; Wirth-Dzieciolowska, 1987 in mice). In females with overcrowded uterine horns, the blood flow to each fetus could be compromised, decreasing their survival.

Placentation in pigs is different: pigs develop epitheliochorial placentas and fetal development is closely associated to the endometrial space available per embryo at implantation. Insufficient placental surface area in females with overcrowded uterine horns has negative effects on fetal growth and survival rate (Knight et al., 1977; Geisert and Schmitt, 2002; van der Waaij et al., 2010).

In addition to the mortality associated to uterine overcrowding, there are many factors that can reduce prenatal survival during the embryonic or the fetal period: a reduced oocyte quality, a greater embryonic diversity leading to embryonic uterine asynchrony, hormone levels and protein patterns of uterine and oviductal secretion (Mocé, 2003).

\subsubsection{Estimation of embryonic and fetal survival}

Embryonic survival is calculated as the proportion of implanted embryos from the number of corpora lutea and fetal survival is calculated as the proportion of kits born from the number of implanted embryos. Besides, prenatal survival is calculated as the proportion of kits born from the number of corpora lutea. The number of implanted embryos can be counted in rabbits in vivo by laparoscopy or post mortem. Similar to ovulation rate, both measurements had a high regression coefficient (0.99; Santacreu et al., 1990), highlighting the accuracy of the laparoscopic method. The laparoscopic method permits the estimation of embryonic and fetal survival in the same female, without affecting litter size. 


\section{Selection for litter size}

\subsection{Conventional selection for litter size}

Litter size has a low heritability (around 0.1; reviewed by Rochambeau 1997; Mocé and Santacreu, 2010 in rabbits; Haley et al., 1988; Rothschild and Bidanel, 1998 in pigs) and the estimated response to selection has been lower than expected in most experiments in rabbits and pigs, around 0.1 young per generation (Gómez et al., 1994; Rochambeau et al., 1998; García and Baselga, 2002; in rabbits; Ollivier, 1981; Bolet et al., 1989; Holl and Robison, 2003 in pigs) (see also Table 1.1 for a review in rabbits). In mice, direct selection for litter size has obtained a higher response than in pigs and rabbits, 0.15 to 0.20 young per generation (Bradford, 1968, 1969; Falconer, 1971; Bakker et al., 1978; Gion et al., 1990). The response observed in rabbits, pigs and mice selected for high litter size has been usually associated to an increment in the number of ova shed without or with small changes in prenatal survival (Bolet et al., 1989; Haley and Lee, 1992 in pigs; Brun et al., 1992; Garcia and Baselga, 2002a in rabbits; Land and Falconer 1969; Falconer 1963; Bakker et al., 1978; Gion et al., 1990 in mice).

Table 1.1: Direct responses in number of kits born alive (NBA) or number of kits weaned (NW) and correlated responses in ovulation rate (OR) and prenatal survival (PS) estimated per generation in rabbits, with their standard errors (in parenthesis).

\begin{tabular}{|c|c|c|c|c|c|c|c|}
\hline & \multirow[b]{2}{*}{ Line } & \multirow[b]{2}{*}{ G } & \multirow[b]{2}{*}{$\mathrm{Cr}$} & \multirow[b]{2}{*}{ Method } & \multicolumn{3}{|c|}{ Responses } \\
\hline & & & & & NBA/NW & OR & PS \\
\hline Gomez et al., 1996 & Prat & 3 & NW & BLUP/REML & 0.09 /year & - & - \\
\hline \multirow{3}{*}{$\begin{array}{l}\text { Rochambeau et al., } \\
1998\end{array}$} & \multirow{2}{*}{1077} & \multirow{2}{*}{18} & \multirow{2}{*}{ NW } & BLUP/REML & 0.08 & $0.06^{*}$ & - \\
\hline & & & & Control & 0.08 & - & - \\
\hline & 2066 & 18 & NBA & BLUP/REML & 0.13 & - & - \\
\hline \multirow{2}{*}{$\begin{array}{l}\text { García and } \\
\text { Baselga, 2002a }\end{array}$} & \multirow{2}{*}{ V } & $0-21$ & \multirow{2}{*}{ NW } & BLUP/REML & $0.09(0.01)$ & - & - \\
\hline & & $15-21$ & & Control & 0.09 & 0.18 & $0.06 \%$ \\
\hline \multirow{2}{*}{$\begin{array}{l}\text { García and } \\
\text { Baselga, 2002b }\end{array}$} & \multirow{2}{*}{$A$} & $1-26$ & \multirow{2}{*}{ NW } & BLUP/REML & $0.18(0.01)$ & - & - \\
\hline & & $17-26$ & & Control & 0.09 & 0.01 & $0.41 \%$ \\
\hline
\end{tabular}

G: Generations; Cr: Criterium of selection

* Response estimated by Brun et al. (1992) after 13 generations of selection. 


\subsection{Selection for hyperprolific lines}

The foundation of hyperprolific lines was proposed by Legault and Gruand (1976) to overcome the low efficiency on the experiments of direct selection for litter size in pigs. A screening of large populations was carried out to identify females with extremely high performance for litter size. The high selection intensities generated were used to initiate the hyperprolific population. Females from hyperprolific lines had higher ovulation rate and higher litter size in spite of having higher prenatal mortality than not hyperprolific females (reviewed by Bidanel et al., 1994). The hyperprolific selection experiments carried out in pigs have obtained successful results. During the last 15 years approximately, litter size has increased by 2 to 4 piglets in the commercial maternal pig lines (for a review see Rothschild and Bidanel, 1998).

In rabbits, the only hyperprolific line was founded by Cifre et al. (1998) by applying hyperprolific criteria and embryo cryopreservation techniques. Selection was performed on hyperprolific does from a large commercial population following criteria detailed by Cifre et al., (1998). After its constitution, the line was selected for litter size at weaning. The hyperprolific line was contrasted to other maternal lines, showing its superiority over crossbred females (around 0.5 young weaned more; Cifre et al., 1998) and over purebred females (0.70 to 1.40 young weaned more; Cifre et al., 1998; Ragab and Baselga, 2011).

\section{Selection for the components of litter size}

Selection experiments for components of litter size are scarce in the literature. There is also little information of the heritabilities of these traits and their correlations (Tables $1.2 a, b)$. The heritability of ovulation rate is moderate, and the heritability of prenatal survival is low in most experiments in mice, pigs and rabbits. Phenotypic and genetic correlations between ovulation rate and litter size range from 0 to 1 . Phenotypic and genetic correlations between prenatal survival and litter size have been usually positive and moderate to high. 
The experiments of selection for components of litter size were proposed as a mean of improving indirectly litter size. Selection for ovulation rate, prenatal survival, its combination in an index and two-stage selection for ovulation rate and litter size have been performed in prolific species.

\subsection{Selection for ovulation rate}

The first experiments of selection for ovulation rate were proposed in mice by Bradford (1969) and Land and Falconer (1969) and in pigs by Zimmerman and Cunningham (1975). Selection for ovulation rate was proposed as an indirect way of increasing litter size, assuming that both traits were correlated and that the heritability of ovulation rate was higher than that of litter size. Moreover, ovulation rate sets the upper limit for litter size and it could be easily counted after slaughter or by laparotomy.

There are five selection experiments for ovulation rate in prolific species, three in pigs (Cunningham et al., 1979; Leymaster and Christenson, 2000; Rosendo et al., 2007) and two in mice (Bradford, 1969 and Land and Falconer, 1969). The estimated responses to selection in these experiments are summarized in Table 1.3. Ovulation rate responded to selection, but it did not lead to a correlated response in litter size showing a decrease in prenatal survival. There is little information about the timing of prenatal mortality in the experiments of selection for ovulation rate, probably due to the difficulties in measuring the number of fetuses in live animals. In pigs, the number of fetuses can only be counted by laparotomy in live animals, because fetuses cannot be individualized by observation of its external surface. However, laparotomy and manipulation of fetuses has been proved to increase prenatal mortality (Neal et al., 1989; Johnson et al., 1999). In mice, fetuses can be safely counted by laparoscopy (Hirsch et al., 1999), but to our knowledge there is no experiment of selection for reproductive traits where this technique has been used. 
Table 1.2a: Estimated heritabilities of ovulation rate (OR) and prenatal survival (PS) and phenotypic and genetic correlations between these traits and litter size (LS) at the day of gestation indicated (DG) in mice, pigs and rabbits.

\begin{tabular}{|c|c|c|c|c|c|c|c|c|c|c|}
\hline & \multirow[b]{2}{*}{ Species } & \multirow[b]{2}{*}{ DG } & \multicolumn{2}{|c|}{ Heritability } & \multicolumn{3}{|c|}{ Phenotypic correlation } & \multicolumn{3}{|c|}{ Genetic correlation } \\
\hline & & & OR & PS & OR, LS & OR, PS & PS, LS & OR, LS & OR, PS & PS, LS \\
\hline Land and Falconer, 1969 & Mice & - & 0.31 & - & - & - & - & - & - & - \\
\hline Bradford, 1969 & Mice & - & 0.10 & - & - & - & - & - & - & - \\
\hline Clutter et al., $1990^{a}$ & Mice & 17 & 0.33 & 0.15 & 0.45 & -0.04 & 0.86 & 0.81 & 0.06 & 0.60 \\
\hline Long et al., 1991 & Mice & Birth & $\begin{array}{c}0.18 \\
(0.07)\end{array}$ & - & - & - & - & $0.62(0.24)$ & - & - \\
\hline Young et al., 1977 & Pigs & 30 & $\begin{array}{c}0.21 \\
(0.20)\end{array}$ & - & - & - & - & - & -0.26 & - \\
\hline Young et al., 1978 & Pigs & Birth & $\begin{array}{c}0.59 \\
(0.12)\end{array}$ & - & 0.06 & - & - & $-0.01(0.46)$ & - & - \\
\hline Cunningham et al., 1979 & Pigs & Birth & $\begin{array}{c}0.42 \\
(0.06)\end{array}$ & - & - & - & - & 0.07 & - & - \\
\hline Bolet et al., 1989 & Pigs & Birth & $\begin{array}{c}0.21 \\
(0.12)\end{array}$ & - & - & - & - & 0.85 & - & - \\
\hline Bidanel et al. 1992 & Pigs & 30 & $\begin{array}{c}0.11 \\
(0.02)\end{array}$ & $\begin{array}{c}0.03 \\
(0.03)\end{array}$ & $\begin{array}{c}0.41 \\
(0.04)\end{array}$ & $\begin{array}{l}-0.13 \\
(0.04)\end{array}$ & $\begin{array}{c}0.87 \\
(0.01)\end{array}$ & $0.98(0.33)$ & -0.13 & 0.99 \\
\hline Haley and Lee, 1992 & Pigs & Birth & $\begin{array}{c}0.30 \\
(0.10)\end{array}$ & 0.00 & $\begin{array}{c}0.21 \\
(0.05)\end{array}$ & $\begin{array}{l}-0.28 \\
(0.05)\end{array}$ & $\begin{array}{c}0.87 \\
(0.01)\end{array}$ & $0.98(1.00)$ & * & * \\
\hline
\end{tabular}


Table 1.2b: Estimated heritabilities of ovulation rate (OR) and prenatal survival (PS) and phenotypic and genetic correlations between these traits and litter size (LS) at the day of gestation indicated (DG) in mice, pigs and rabbits (continuation of Table 1.2a).

\begin{tabular}{|c|c|c|c|c|c|c|c|c|c|c|}
\hline & \multirow[b]{2}{*}{ Species } & \multirow[b]{2}{*}{ DG } & \multicolumn{2}{|c|}{ Heritability } & \multicolumn{3}{|c|}{ Phenotypic correlation } & \multicolumn{3}{|c|}{ Genetic correlation } \\
\hline & & & OR & PS & OR, LS & OR, PS & PS, LS & OR, LS & OR, PS & PS, LS \\
\hline Bidanel et al., 1996 & Pigs & 30 & $\begin{array}{l}0.27 \\
(0.02)\end{array}$ & $\begin{array}{c}0.08 \\
(0.03)\end{array}$ & - & $\begin{array}{l}-0.12 \\
(0.04)\end{array}$ & - & - & $-0.11(0.15)$ & - \\
\hline Johnson et al., 1999 & Pigs & 50 & 0.24 & 0.14 & 0.03 & -0.47 & 0.48 & 0.24 & -0.86 & 0.36 \\
\hline $\begin{array}{l}\text { Ruíz-Flores and Johnson, } \\
2001^{\text {b }}\end{array}$ & Pigs & Birth & $\begin{array}{c}0.42 \\
(0.06)\end{array}$ & $\begin{array}{c}0.12 \\
(0.09)\end{array}$ & 0.16 & 0.59 & -0.69 & 0.52 & 0.83 & -0.04 \\
\hline Rosendo et al., $2007^{c}$ & Pigs & Birth & 0.34 & 0.14 & 0.06 & -0.18 & 0.82 & 0.41 & -0.26 & 0.66 \\
\hline Blasco et al., 1993a & Rabbits & Birth & $\begin{array}{c}0.21 \\
(0.11)\end{array}$ & $\begin{array}{c}0.23 \\
(0.10)\end{array}$ & $\begin{array}{c}0.25 \\
(0.06)\end{array}$ & $\begin{array}{l}-0.30 \\
(0.05)\end{array}$ & $\begin{array}{c}0.84 \\
(0.02)\end{array}$ & $\begin{array}{c}0.36 \\
(0.31)\end{array}$ & $-0.14(0.35)$ & $\begin{array}{c}0.87 \\
(0.08)\end{array}$ \\
\hline Bolet et al., 1994 & Rabbits & - & $\begin{array}{c}0.24 \\
(0.04)\end{array}$ & - & - & - & - & - & - & - \\
\hline
\end{tabular}

* Not estimated because the estimate of the heritability of PS was zero.

${ }^{a}$ Standard errors range from 0.05 to 0.06 for the heritabilities and from 0.06 to 0.66 for the genetic correlations. Litter size was estimated as the number of fetuses at $d 17$ of gestation.

${ }^{b}$ They measure prenatal loss instead of prenatal survival.

${ }^{\mathrm{c}}$ Standard errors range from 0.01 to 0.03 for the heritabilities and from 0.03 to 0.13 for the correlation. 
Table 1.3: Direct response in ovulation rate (OR) and correlated responses in total number born (TNB) and prenatal survival (PS) with their standard errors (SE) estimated per generation in the experiments of selection for OR in mice and pigs.

\begin{tabular}{|c|c|c|c|c|c|c|c|c|c|}
\hline & Species & G & $\begin{array}{l}\text { Selection } \\
\text { criterium }\end{array}$ & $\begin{array}{l}\text { Mean OR } \\
\text { (SD) }\end{array}$ & Parity & Mean LS & $\begin{array}{c}\text { Response in OR } \\
\text { (SE) }\end{array}$ & $\begin{array}{c}\text { Response in TNB } \\
\text { (SE) }\end{array}$ & $\begin{array}{c}\text { Response in PS } \\
\text { (SE) }\end{array}$ \\
\hline $\begin{array}{l}\text { Land and Falconer, } \\
1969\end{array}$ & Mice & 12 & OR at $2^{\text {nd }}$ estrus & 16.2 & 1 & 9.6 & $0.40^{b}$ & $\underset{b}{\text { no clear changes }}$ & - \\
\hline \multirow{3}{*}{ Bradford, 1969} & \multirow{3}{*}{ Mice } & \multirow{3}{*}{11} & \multirow{3}{*}{ OR at $1^{\text {st }}$ estrus } & \multirow{3}{*}{$10.1(2.6)$} & \multirow{3}{*}{1} & \multirow{3}{*}{8} & $0.26(0.11)^{a}$ & $0.07(0.05)^{a}$ & - \\
\hline & & & & & & & & & \\
\hline & & & & & & & $0.12^{b}$ & $0.02^{b}$ & $-0.7 \%^{b}$ \\
\hline \multirow{2}{*}{$\begin{array}{l}\text { Cunningham et al., } \\
1979\end{array}$} & \multirow[t]{2}{*}{ Pigs } & \multirow[t]{2}{*}{$9^{1}$} & \multirow{2}{*}{ OR at $2^{\text {nd }}$ estrus } & \multirow[t]{2}{*}{$14.4(2.9)$} & \multirow[t]{2}{*}{$2,3,4$} & \multirow[t]{2}{*}{8.5} & $0.38(0.08)^{a, 1}$ & $0.15(0.13)^{a}$ & - \\
\hline & & & & & & & $0.49(0.10)^{b, 1}$ & $0.06(0.07)^{b}$ & $-1.6 \%(0.5 \%)^{b, 2}$ \\
\hline \multirow[t]{2}{*}{$\begin{array}{l}\text { Leymaster and } \\
\text { Christenson, } 2000\end{array}$} & \multirow[t]{2}{*}{ Pigs } & \multirow[t]{2}{*}{10} & \multirow[t]{2}{*}{$\begin{array}{l}\text { OR at estrus of } \\
\text { conception }\end{array}$} & - & - & - & $0.29^{b}$ & $0.06^{b}$ & - \\
\hline & & & & \multirow{3}{*}{$14.1(2.8)$} & \multirow{3}{*}{1,2} & \multirow{3}{*}{$10.3(2.9)$} & $0.49(0.10)^{c}$ & $0.08(0.11)^{c}$ & $-1.0 \%(0.9 \%)^{c}$ \\
\hline \multirow[t]{2}{*}{ Rosendo et al., 2007} & \multirow[t]{2}{*}{ Pigs } & \multirow[t]{2}{*}{6} & \multirow[t]{2}{*}{ OR at puberty } & & & & & & \\
\hline & & & & & & & $0.51(0.10)^{b}$ & $0.06(0.11)^{b}$ & $-1.6 \%(0.9 \%)^{b}$ \\
\hline
\end{tabular}

G: number of generations; Parity: parity number for litter size

${ }^{\mathrm{a}}$ Regression of line means on generation number; ${ }^{\mathrm{b}}$ Response estimated with a control population; ${ }^{\mathrm{c}} \mathrm{REML}$ estimate

${ }^{1}$ Johnson et al., 1984, responses estimated at generation 10.

${ }^{2}$ Geisert et al., 1978: response per generation in survival at $d 30$ and at $d 70,0.5 \%$ and $1.1 \%$, respectively. 


\subsection{Selection for prenatal survival}

There are two experiments of selection for prenatal survival in polytocous species, one in pigs (Rosendo et al., 2007) and the other one in mice (Bradford, 1969). In pigs, the selection criterion was the average prenatal survival over the first two parities corrected for ovulation rate (prenatal survival $+0.018 \times$ ovulation rate). In mice, the number of normal fetuses at $d 16$ was used as an estimator of litter size at birth, and selection was based on [(number of normal fetuses at $d 16$ / ovulation rate) $x$ number of normal fetuses at $d$ 16]. The objective in both experiments was to select for prenatal survival avoiding selection against ovulation rate. Responses to selection in pigs and mice are presented in Table 1.4. Selection for prenatal survival increased litter size both in pigs and mice compared to a control line, and a correlated response in ovulation rate was observed in mice. In mice, the increases in ovulation rate and litter size in the line selected for prenatal survival nearly equalled those of two contemporarily lines directly selected for ovulation rate and for litter size, respectively. In pigs, it is not possible to determine if the estimated response was higher than response to direct selection for litter size due to the high standard error of the estimate and to the absence of a contemporary line selected for litter size, as in mice. Summarizing, selection for prenatal survival increased litter size, but it was not more effective than direct selection for litter size.

Table 1.4: Responses in prenatal survival (PS), ovulation rate (OR) and litter size (LS) estimated per generation in pigs and mice selected for prenatal survival, with their standard errors (in parenthesis).

\begin{tabular}{|c|c|c|c|c|c|}
\hline \multicolumn{2}{|c|}{ Species } & \multicolumn{2}{|c|}{ Pigs } & \multicolumn{2}{|c|}{ Mice } \\
\hline \multicolumn{2}{|c|}{ Generations } & \multicolumn{2}{|c|}{6} & \multicolumn{2}{|c|}{11} \\
\hline Methoc & & $\begin{array}{c}\text { Control } \\
\text { population }\end{array}$ & REML $^{1}$ & $\begin{array}{c}\text { Control } \\
\text { population }{ }^{2}\end{array}$ & Regression ${ }^{2^{*}}$ \\
\hline \multirow{3}{*}{ 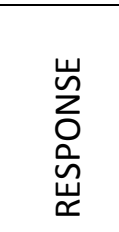 } & PS (\%) & $1.0(0.9)$ & $0.8(0.9)$ & 0.8 & $0.4(0.4)$ \\
\hline & OR (ova) & $0.04(0.11)$ & $0.11(0.11)$ & 0.15 & $0.23(0.09)$ \\
\hline & LS (kits) & $0.21(0.11)$ & $0.24(0.11)$ & 0.20 & $0.25(0.06)$ \\
\hline
\end{tabular}

${ }^{1}$ Rosendo et al., 2007; ${ }^{2}$ Bradford, 1969

${ }^{*}$ Regression of generation mean on generation number 


\subsection{Selection for uterine capacity}

Selection for increased uterine capacity was proposed as an indirect way of improving litter size changing prenatal survival (Bennett and Leymaster, 1989). Christenson et al. (1987) defined uterine capacity as the maximum number of fetuses a dam can support at birth when the number of ova shed is not a limiting factor. They suggested that litter size of unilaterally ovariectomized-hysterectomized females could measure uterine capacity, because the remaining ovary nearly doubled its ovulation rate and the remaining uterine horn would be overcrowded by fetuses. In mice and rabbits, the number of total born from unilaterally ovariectomized females represented their uterine capacity (Clutter et al., 1990 in mice; Blasco et al., 1994 in rabbits), because their duplex uterus does not allow uterine transmigration. In these species, litter size of unilaterally ovariectomized females was approximately $80 \%$ of the size of intact does, indicating that the uterine horn capacity in intact females could still increase through selection (Blasco et al., 1994 in rabbits; Lamberson et al., 1989 in mice).

Table 1.5: Responses to selection to increase uterine capacity (UC) and correlated responses in ovulation rate (OR), litter size (LS) and prenatal survival (PS) estimated per generation.

\begin{tabular}{|c|c|c|c|c|c|c|}
\hline \multicolumn{2}{|c|}{ Species } & \multicolumn{2}{|c|}{$\begin{array}{l}\text { Rabbits } \\
\left(1^{\text {st }} \text { exp.) }\right.\end{array}$} & $\begin{array}{l}\text { Rabbits } \\
\left(2^{\text {nd }} \text { exp.) }\right.\end{array}$ & Pigs & Mice \\
\hline \multicolumn{2}{|c|}{ Generations } & \multicolumn{2}{|c|}{10} & 4 & 11 & $13^{6}, 21^{7}$ \\
\hline \multicolumn{2}{|c|}{ Method } & $\begin{array}{l}\text { Control } \\
\text { Population }\end{array}$ & $\begin{array}{l}\text { Genetic } \\
\text { Trends }^{3}\end{array}$ & $\begin{array}{l}\text { Genetic } \\
\text { Trends }{ }^{4}\end{array}$ & $\begin{array}{l}\text { Control } \\
\text { population }\end{array}$ & $\begin{array}{c}\text { Control } \\
\text { population }\end{array}$ \\
\hline \multirow{4}{*}{ 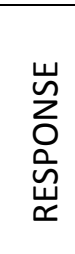 } & UC (kits) & $-0.01^{1}$ & 0.08 & -0.15 & 0.11 & $0.10(0.02)^{6^{*}}$ \\
\hline & OR (ova) & $-0.03^{2}$ & 0.03 & -0.3 & 0.00 & $0.03^{6}$ \\
\hline & LS (kits) & $0.05^{2}$ & - & - & 0.08 & $0.00^{7}$ \\
\hline & PS (\%) & $0.5^{2}$ & 0.4 & 0 & - & $0.3^{6}$ \\
\hline
\end{tabular}

${ }^{1}$ Mocé et al., 2005; ${ }^{2}$ Santacreu et al., 2005; ${ }^{3}$ Blasco et al., 2005; ${ }^{4}$ data calculated from results presented in Santacreu et al., 1994, assuming a symmetric response; ${ }^{5}$ Leymaster and Christenson, 2000; ${ }^{6}$ Gion et al., 1990; ${ }^{7}$ Kirby and Nielsen, 1993;

*Standard errors (SE) in parenthesis

There is one experiment of selection for uterine capacity in pigs (Leymaster and Christenson, 2000) and their results have not been fully published yet. There are three 
more experiments of selection for uterine capacity: two experiments of divergent selection in rabbits (first experiment: Blasco et al., 2005; Mocé et al., 2005; Santacreu et al., 2005; second experiment: Bolet et al., 1994; Santacreu et al., 1994) and one experiment in mice (Clutter et al., 1990; Gion et al., 1990; Kirby and Nielsen, 1993). In short, direct responses to increase uterine capacity and correlated responses in litter size were low or close to zero in rabbits, pigs and mice.

\subsection{Selection for an index of ovulation rate and prenatal survival}

The indexes of ovulation rate and prenatal survival were constructed to maximize the expected change in litter size at birth using adequate economic weights for each trait (Johnson et al., 1984). To our knowledge, there are two experiments of selection for an index of ovulation rate and prenatal survival, one in pigs (Johnson et al., 1984; Neal et al., 1989; Casey et al., 1994; Johnson et al., 1999) and the other in mice (Clutter et al., 1990; Gion et al., 1990; Kirby and Nielsen, 1993). In pigs, the index was recalculated during the experiment to optimize response to selection. Selection was efficient in increasing litter size when compared to the control line (Table 1.6). This response was similar to the observed response to direct selection for litter size in other experiments. In mice, response to selection was estimated by comparison with a control line and with a line selected for litter size (Gion et al., 1990). As in pigs, litter size increased with selection compared with the control line (Table 1.6), but it increased at a similar rate to the line selected for litter size. The increase in litter size in the line selected for the index was due to a higher ovulation rate and prenatal survival in the selected line than in the control line. The index was used along the selection experiment without reweighting their components. The authors suggested that selection for the index could have been even more effective than selection for litter size using optimally weighted components. 
Table 1.6: Responses to selection in ovulation rate (OR), litter size (LS) and prenatal survival (PS) estimated per generation in pigs and mice selected for an index of ovulation rate and prenatal survival, with their standard errors (in parenthesis).

\begin{tabular}{|c|c|c|c|c|}
\hline \multicolumn{2}{|l|}{ Species } & \multicolumn{2}{|c|}{ Pigs } & Mice \\
\hline \multicolumn{2}{|c|}{ Generations } & \multicolumn{2}{|c|}{$10^{1}, 11^{2}$} & $13^{3}$ \\
\hline \multicolumn{2}{|l|}{ Method } & Control population ${ }^{1}$ & REML $^{2}$ & Control population ${ }^{3}$ \\
\hline \multirow{3}{*}{ 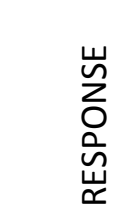 } & OR (ova) & $0.78(0.04)$ & $0.67(0.12)$ & $0.15^{3}$ \\
\hline & LS (kits) & $0.11(0.05)$ & $0.21(0.04)$ & $0.17(0.01)^{3}$ \\
\hline & PS (\%) & $-0.9(0.1)$ & $-0.01(0.01)$ & $0.15^{3}$ \\
\hline
\end{tabular}

${ }^{1}$ Casey et al., 1996; ${ }^{2}$ Johnson et al., 1999; ${ }^{3}$ Gion et al., 1990.

\subsection{Two-step selection for ovulation rate and litter size}

Two-step selection was performed in pigs to increase indirectly litter size (Ruíz-Flores and Johnson, 2001): first, females born in litters with highest litter size at birth were selected. Secondly, these females underwent laparotomy to count their ovulation rate at second estrus, and they were selected on their ovulation rate. Response to 8 generations of selection, estimated as the regression of estimated breeding value line differences, was greater than expected for the number total born $0.33 \pm 0.06$ pigs per generation). The correlated response in number of born alive was $0.21 \pm 0.06$ pigs per generation. These responses are higher than the responses observed in other experiments of selection for litter size in pigs.

In rabbits, an experiment of two-step selection of ovulation rate and litter size is currently being carried out in the Universidad Politécnica de Valencia (UPV). No results from this experiment have been published yet.

Taking results together, in rabbits, selection for uterine capacity had not been successful and there was no previous experiment of selection for ovulation rate. At the beginning of our experiment, there was only one experiment in pigs (Cunningham et al., 1979) and two in mice (Bradford, 1969 and Land and Falconer, 1969), and generalizations from only 3 experiments should be made carefully. Selection for 
ovulation rate was proposed in rabbits, expecting different results than in the experiments in pigs and mice.

In our population, $85-90 \%$ of the females had a different number of corpora lutea in the right and the left ovary. The absence of uterine transmigration in rabbits (Adams, 1960b) can cause an overcrowded uterine horn, while the other one is less occupied. The following hypothesis was formulated: if ovulation rate increased with selection in both ovaries, the ovary with higher ovulation rate could already have its uterine horn overcrowded, while the ovary with less ovulation rate could shed more ova able to implant. Therefore, the number of implanted embryos would possibly increase as an average, and that would possibly lead to a higher litter size. Indeed, in an experiment comparing intact rabbit females with unilaterally ovariectomized females showed that the latter nearly doubled the ovulation rate and uterine capacity in the remaining horn (Blasco et al., 1994). This might indicate that selection for ovulation rate could increase litter size, because the maximum uterine horn capacity has not been reached.

\section{Literature cited}

Adams, C. E. 1960a. Prenatal mortality in the rabbit Oryctolagus cuniculus. J. Reprod. Fertil. 1:36-44.

Adams, C. E. 1960b. Studies on prenatal mortality in the rabbit, Oryctolagus cuniculus: The amount and distribution of loss before and after implantation. J. Endocrinol. 19:325-344.

Al-Shorepy, S. A., A. C. Clutter, R. M. Blair, and M. K. Nielsen. 1992. Effects of three methods of selection for litter size in mice on pre-implantation embryonic development. Biol. Reprod. 46:958-963.

Argente, M. J., A. Blasco, J. A. Ortega, C. S. Haley, and P. M. Visscher. 2003. Analyses for the presence of a major gene affecting uterine capacity in unilaterally ovariectomized rabbits. Genetics 163:1061-1068. 
Bakker, H., J. H. Wallinga, and R. D. Politiek. 1978. Reproduction and body weight of mice after long-term selection for large litter size. J. Anim. Sci. 46:1572-1580.

Balaban B., and B. Urman 2006. Effect of oocyte morphology on embryo development and implantation. Reprod Biomed Online 12:608-615.

Barnes, F. L. 2000. The effect of the early uterine environment on the subsequent development of embryo and fetus. Theriogenology 53:649-658.

Bazer, F. W., W. W. Thatcher, F. Martinat-Botte, and M. Terqui. 1998. Conceptus development in Large White and prolific Chinese Meishan pigs. J. Reprod. Fertil. 84:37-42.

Bennett, G. L., and K. A. Leymaster. 1989. Integration of ovulation rate, potential embryonic viability and uterine capacity into a model of litter size in swine. J. Anim. Sci. 67:1230-1241.

Bidanel, J. P., A. Ducos, E. Groeneveld, J. Gruand, H. Lagant, and C. Legault. 1992. Genetic variability in components of litter size in French Large White gilts. $43^{\text {rd }}$ Ann. Meet. European Association for Animal Production, Madrid, Spain.

Bidanel, J. P., J. Gruand, and C. Legault. 1994. An overview of twenty years of selection for litter size in pigs using "hyperprolific" schemes. Proc. 5th World Congr. Genet. Appl. Livest. Prod., Guelph, Ontario, Canada 17:512-515.

Bidanel, J. P., J. Gruand, and C. Legault. 1996. Genetic variability of age and weight at puberty, ovulation rate and embryo survival in gilts and relations with production traits. Genet. Sel. Evol. 28:103-117.

Blasco, A., M. A. Santacreu, R. Thompson, and C. S. Haley. 1993. Estimates of genetic parameters for ovulation rate, prenatal survival and litter size in rabbits from an elliptical experiment. Livest. Prod. Sci. 34:163-174.

Blasco, A., M. J. Argente, C. Haley, and M. A. Santacreu. 1994. Relationships between components of litter size in unilaterally ovariectomized and intact rabbit does. J. Anim. Sci. 72:3066-3072. 
Blasco, A., J. A. Ortega, M. A. Santacreu, and A. Climent. 2005. Divergent selection for uterine capacity in rabbits. I. Genetic parameters and response to selection. J. Anim. Sci. 83:2297-2302.

Bolet, G., L. Ollivier, and P. Dando. 1989. Sélection sur la prolificité chez le porc. I. Résultats d'une expérience de sélection sur onze générations. Genet. Sel. Evol. 21:93-106.

Bolet, G., M. A. Santacreu, M. J. Argente, A. Climent, and A. Blasco. 1994. Divergent selection for uterine efficiency in unilaterally ovariectomized rabbits. I. Phenotypic and genetic parameters. Proc. 5th World Congr. Genet. Appl. Livest. Prod., Guelph, Ontario, Canada 19:261-264.

Bradford, G. E. 1968. Selection for litter size in mice in the presence and absence of gonadotropin treatment. Genetics 58:283-295.

Bradford, G. E. 1969. Genetic control of ovulation rate and embryo survival in mice. I. Response to selection. Genetics 61:907-918.

Brun, J. M., G. Bolet, and J. Ouhayoun. 1992. The effects of crossbreeding and selection on productive and reproductive traits in a triallel experiment between three strains of rabbits. J. Appl. Rabbit Res. 15:181-189.

Carney EW, A. R. Scialli, R. E. Watson, and J. M. De Sesso. 2004. Mechanisms regulating toxicant disposition to the embryo during early pregnancy: an interspecies comparison. Birth Defects Res. Part C 72:345-60.

Casey, D., T. A. Rathje, and R. K. Johnson. 1994. Response to ten generations of index selection for components of litter size in swine. Proc. 5th World Congr. Genet. Appl. Livest. Prod., Guelph, Ontario, Canada 17:315-317.

Christenson, R. K., K. A. Leymaster, and L. D. Young. 1987. Justification of unilateral hysterectomy-ovariectomy as a model to evaluate uterine capacity in swine. J. Anim. Sci. 65:738-744. 
Cifre, P., M. Baselga, F. Gacia-Ximenez, and J. Vicente. 1998. Performance of a hyperprolific rabbit line. I. Litter size traits. J. Anim. Breed. Genet. 115:131-138.

Clutter, A. C., M. K. Nielsen, and R. K. Johnson. 1990. Alternative methods of selection for litter size in mice: I. Characterization of base population and development of methods. J. Anim. Sci. 68:3536-3542.

Cunningham, P. J., M. E. England, L. D. Young, and D. R. Zimmerman. 1979. Selection for ovulation rate in swine: Correlated response in litter size and weight. J. Anim. Sci. 48:509-516.

Duncan, S. L. B. 1969. The partition of uterine blood flow in the pregnant rabbit. J. Physiol. (Lond.) 204:421-433.

Eady, S. 2008. Technology Advances and Innovation in the Meat Rabbit Industry in Europe. Rural Industries Research and Development Corporation 08/036.

Falconer, D. S. 1963. Qualitatively different responses to selection in opposite directions. In: Statistical genetics and plant breeding. NAS-NRC Publ. 982:487490.

Falconer, D. S. 1971. Improvement of litter size in a strain of mice at a selection limit. Genet. Res. 17:215-235.

Food and Agriculture Organization (FAO). 2011. Food Outlook. Global Market Analysis. http://www.fao.org/docrep/014/al978e/al978e00.pdf

Foxcroft, G. R., W. T. Dixon, S. Novak, C. T. Putman, S. C. Town, and M. D. Vinsky. 2006. The biological basis for prenatal programming of postnatal performance in pigs. J. Anim. Sci. 84(Suppl): E105-E112.

Fujimoto, S., J. M. R. Rawson, and W. R. Dukelow. 1974. Hormonal influences on the time of ovulation in the rabbit as determined by laparoscopy. J. Reprod. Fertil. 38:97-103. 
García, M. L., and M. Baselga. 2002a. Estimation of genetic response to selection in litter size of rabbits using a cryopreserved control population. Livest. Prod. Sci. 74:45-53.

García, M. L., and M. Baselga. 2002b. Genetic response to selection for reproductive performance in a maternal line of rabbits. World Rabbit Science, 10(2):71-76.

Geisert, R. D., and R. A. M. Schmitt. 2002. Early embryonic survival in the pig: Can it be improved? J. Anim. Sci. 80(E-Suppl.): E54-E65.

Gion, J. M., A. C. Clutter, and M. K. Nielsen. 1990. Alternative methods of selection for litter size in mice: II. Response to thirteen generations of selection. J. Anim. Sci. 68:3543-3556.

Gómez, E.A., O. Rafel, J. Ramón, and M. Baselga. 1996. A genetic study of a line selected on litter size at weaning. In Proc. 6th World Rabbit Congress, Toulouse, France 2:289-292.

Hafez, E. S. E., and Y. Tsutsumi. 1966. Changes in endometrial vascularity during implantation and pregnancy in the rabbit. Am. J. Anat. 118:249-282.

Haley, C. S., Avalos, E., and Smith, C. 1988. Selection for litter size in the pig. Anim. Breed. Abstr. 56:317-332.

Haley, C. S., and G. J. Lee. 1992. Genetic factors contributing to variation in litter size in British Large White gilts. Livest. Prod. Sci. 30:99-113.

Hirsch E, T. Otto, R. Blanchard, and J. O. Rosenberg. 1999. Mouse laparoscopy. J. Am. Assoc. Gynecol. Laparosc. 6(2):173-177.

Holl, J. W., and O. W. Robison. 2003. Results from nine generations of selection for increased litter size in swine. J. Anim. Sci. 81:624-629.

INRA-SAGA, Institut National de la Recherche Agronomique-Station d'amélioration génétique des animaux. http://www.avicampus.fr/PDF/PDFlapin/selectionlapin1.pdf 
Joakimsen, O., and R.L. Baker. 1977. Selection for litter size in mice. Acta Agriculturae Scandinavica 27:301-318.

Johnson, R. K., D. R. Zimmerman, and R. J. Kittok. 1984. Selection for components of reproduction in swine. Livest. Prod. Sci. 11:541-558.

Johnson, R. K., M. K. Nielsen, and D. S. Casey. 1999. Responses in ovulation rate, embryonal survival and litter traits in swine to 14 generations of selection to increase litter size. J. Anim. Sci. 77:541-557.

Khalil, M. H., and A. M. Al-Saef. 2008. Methods, criteria, techniques and genetic responses for rabbit selection: a review. 9th World Rabbit Congress, Verona, Italy. Pages 1-22

Kirby, Y. K., and M. K. Nielsen. 1993. Alternative methods of selection for litter size in mice: III. Response to 21 generations of selection. J. Anim. Sci. 71: 571-578.

Knight, J. W., F. W. Bazer, W. W. Thatcher, D. E. Franke, and H. D. Wallace. 1977. Conceptus development in intact and unilaterally hysterectomizedovariectomized gilts: interrelations among hormonal status, placental development, fetal fluids and fetal growth. J. Anim. Sci. 44:620-637.

Koenig, J. L. F., D. R. Zimmerman, F. E. Eldrige, and J. D. Kopf. 1986. The effect of superovulation and selection for high ovulation rate on chromosomal abnormalities in swine ova. J. Anim. Sci. 63(Suppl.1):202 (Abstr.).

Krisher, R.L. 2004. The effect of oocyte quality on development. J. Anim. Sci. 82 (E. Suppl.): E14-E23.

Lamberson, W. R., R. M. Blair, and C. R. Long. 1989. Effect of unilateral ovariectomy on reproductive traits of mice. Anim. Reprod. Sci. 20:49-55.

Land, R. B., and D. S. Falconer. 1969. Genetic studies of ovulation rate in the mouse. Genet. Res. 13:25-46.

Legault, C., and J. Gruand. 1976. Improvement of litter size in sows by the creation of a "hyperprolific" line and the use of artificial insemination: Theory and 
preliminary experimental results. Journeés de la Recherche Porcine en France 8:201-212.

Leiser, R., and P. Kaufmann. 1994. Placental structure: in a comparative aspect. Experimental and Clinical Endocrinology 102:122-134.

Leymaster, K. A., and R. K. Christenson. 2000. Direct and correlated responses to selection for ovulation rate or uterine capacity in swine. J. Anim. Sci. 78 (Suppl.1):68. (Abstr.).

Long, C. R., W. R. Lamberson, and R. O. Bates. 1991. Genetic correlations among reproductive traits and uterine dimensions in mice. J. Anim. Sci. 69:99-103.

Luberda Z., 2005. The role of glutathione in mammalian gametes. Biol. Reprod. 5:5-17.

Mocé, M. L. 2003. Maternal and embryonic genetic effects on prenatal survival in an experiment of divergent selection for uterine capacity in rabbit. Universidad Politécnica de Valencia, Tesis doctoral.

Mocé, M. L., M. A. Santacreu, A. Climent, and A. Blasco. 2004. The effect of divergent selection for uterine capacity on prenatal survival in rabbits: Maternal and embryonic genetic effects. J. Anim. Sci. 82:68-73.

Mocé, M. L., M. A. Santacreu, A. Climent, and A. Blasco. 2005. Divergent selection for uterine capacity in rabbits. III. Responses in uterine capacity and its components estimated with a cryopreserved control population. J. Anim. Sci. 83:2308-2312.

Mocé, M.L., A. Blasco, and M.A. Santacreu. 2010. In vivo development of vitrified rabbit embryos: Effects on prenatal survival and placental development. Theriogenology 73:704-710.

Mocé, M. L. and M. A. Santacreu. 2010. Genetic improvement of litter size in rabbits: a review. CD-Proc. 9th World Congr. Genet. Appl. Livest. Prod. Leipzig, Germany. 
Neal, S. M., R. K. Johnson, and R. J. Kittok. 1989. Index selection for components of litter size in swine: Response to five generations of selection. J. Anim. Sci. 67:1933-1945.

Ollivier, L., and G. Bolet. 1981. Selection for prolificacy in the pig: results of a ten generation selection experiment. Journee Rech. Porc. France 13:261-268.

Pascual, M., P. Serrano, C. Torres, and E. Gomez. 2011. Algunos conceptos para la mejora de la rentabilidad en explotaciones cunículas. 36 Symposium de cunicultura de ASESCU, Peñíscola, Spain. Pages 18-23.

Peiró, R., M. A. Santacreu, Á. Climent, and A. Blasco. 2007. Early embryonic survival and embryo development in two divergent lines of rabbits selected for uterine capacity. J. Anim. Sci. 85:1634-1639.

Pope, W. F. 1988. Uterine Asynchrony: A Cause of Embryonic Loss. Biol. of Reprod. 39: 999-1003.

Pope, W. F., S. Xie, D. M. Broermann, and K. P. Nephew. 1990. Causes and consequences of early embryonic diversity in pigs. J. Reprod. Fertil. Suppl. $10: 251-260$.

Ragab, M., and M. Baselga. 2011. A comparison of reproductive traits of four maternal lines of rabbits selected for litter size at weaning and founded on different criteria. Livest. Sci. 136:201-206.

Rausell, F., and J. J. Tarín. 2005. Función del glutatión reducido durante la maduración y fecundación de ovocitos y desarrollo pre-implantatorio de embriones in vitro de mamíferos. Revista Iberoamericana de Fertilidad. Vol. 22- no 6.

REGA, Registro General de Explotaciones Ganaderas. 2010. http://www.marm.es/app/vocwai/documentos/Adjuntos_AreaPublica/INDICAD ORES\%20ECON\%C3\%93MICOS\%20SECTOR\%20CUN\%C3\%8DCOLA\%202010.pdf 
Revelli, A., L. Delle Piane, S. Casano, E. Molinari, M. Massobrio, and P. Rinaudo. 2009. Follicular fluid content and oocyte quality: from single biochemical markers to metabolomics. Reprod. Biol. Endocr. 7:40-53.

Reynolds, S. R. M. 1946. The relation of hydrostatic conditions in the uterus to the size and shape of the conceptus during pregnancy. A concept of uterine accommodation. Anat. Ree. 95, 283.

Rochambeau, H. de. 1997. Genetics of the rabbit for meat production: What's new since the World Rabbit Congress held in Budapest in 1988? A review. World Rabbit Science 5(2):77-82.

Rochambeau, H. de, R. Duzert, and F. Tudela. 1998. Long term selection experiment in rabbit. Estimation of genetic progress on litter size at weaning. Proc. 6th World Congr. Genet. Appl. Livest. Prod., Armidale, Australia, Vol. 26.

Rosell, J. M. 2000. Biología. In: Enfermedades del conejo. Ed. Mundi-Prensa, Madrid, España. Pages 55-127.

Rosendo, A., T. Druet, J. Gogué, and J. P. Bidanel. 2007. Direct responses to six generations of selection for ovulation rate or prenatal survival in Large White pigs. J. Anim. Sci. 85:356-364.

Rothschild, M. F., and Bidanel, J. P. 1998. Biology and genetics of reproduction. In: The Genetics of the Pig. M.F. Rothschild and A. Ruvinsky (eds.) Wallingford (UK): CAB International. Pages 313-343.

Ruíz-Flores, A., and R. K. Johnson. 2001. Direct and correlated responses to two-stage selection for ovulation rate and number of fully formed pigs at birth in swine. J. Anim. Sci. 79:2286-2297.

Santacreu, M. A., M. P. Viudes, and A. Blasco. 1990. Evaluation par coelioscopie des corps jaunes et des embryons. Influence sur la taillé de portée chez la lapine. Reprod. Nutr. Dev. 30:583-588. 
Santacreu, M. A., M. J. Argente, A. Climent, A. Blasco, and G. Bolet. 1994. Divergent selection for uterine efficiency in unilaterally ovariectomized rabbits. II. Response to selection. Proc. 5th World Congr. Genet. Appl. Livest. Prod. 19:265-267.

Santacreu, M. A., M. L. Mocé, A. Climent, and A. Blasco. 2005. Divergent selection for uterine capacity in rabbits. II. Correlated response in litter size and its components estimated with a cryopreserved control population. J. Anim. Sci. 83:2303-2307.

Soede, N. M., C. C. H. Wetzels, W. Zondag, M. A. I. de Koning, and B. Kemp. 1995. Effects of time of insemination relative to ovulation, as determined by ultrasonography, on fertilization rate and accessory sperm count in sows. J. Reprod. Fertil. 104:99-106.

Theau-Clement, M., P. Salvetti, G. Bolet, G. Saleil, and T. Joly. 2009. Influence de l'intervalle entre le sevrage et l'insemination sur la production d'embryons et leur qualité chez la lapine. 13émes Journées de la Recherche Cunicole. INRAITAVI, Le Mans, France. Pages 125-128.

Torrés, S., F. Hulot, and M. Meunier. 1984. Étude comparée du développement et de la mortalité embryonnaire chez deux genotypes de lapines. 3rd World Rabbit Congress. Rome, Italy 2:417-425.

van der Waaij, E. H., W. Hazeleger, N. M. Soede, B. F. A. Laurenssen, and B. Kemp. 2010. Effect of excessive, hormonally induced intrauterine crowding in the gilt on fetal development on day 40 of pregnancy. J. Anim. Sci. 88:2611-2619.

Wilde, M. H., S. Xie, M. L. Day, and W. F. Pope. 1988. Survival of small and large littermate blastocysts in swine after synchronous and asynchronous transfer procedures. Theriogenology 30:1069-1074.

Wilmut I., D. I. Sales, and C. J. Ashworth. 1986. Maternal and embryonic factors associated with prenatal loss in mammals. J. Reprod. Fert. 76:851-864.

Wirth-Dzieciolowska, E. M. 1987. Survival of embryos in relation to the vasculature of implantation places in laboratory mice. Genetica Polonica 28:127-130. 
Xie, S., D. M. Broermann, K. P. Nephew, R. D. Geisert, and W. F. Pope. 1990. Ovulation and Early Embryogenesis in Swine. Biol. Reprod. 43:236-240.

Young, L. D., R. K. Johnson, and I. T. Omtveldt. 1977. An analysis of the dependency structure between a gilt's prebreeding and reproductive traits. I. Phenotypic and genetic correlations. J. Anim. Sci. 44:557-564.

Young L. D., R. A. Pumfrey, P. J. Cunningham, and D. R. Zimmerman. 1978. Heritabilities and genetic and phenotypic correlations for prebreeding traits, reproductive traits and principal components. J. Anim. Sci. 46:937-949.

Zimmerman, D. R., and P. J. Cunningham. 1975. Selection for ovulation rate in swine: population, procedures and ovulation response. J. Anim. Sci. 40:61-69. 


\section{Chapter 2}

\section{Objectives}

P. Laborda

Instituto de Ciencia y Tecnología Animal, Universidad Politécnica de Valencia, 46071 Valencia. Spain. 

Selection for litter size has obtained a lower than expected response to selection. Therefore, alternative methods have been developed to increase litter size. Selection for ovulation rate was proposed as an indirect method to improve litter size. The objectives of this Thesis are:

1. To study the phenotypic and genetic parameters of ovulation rate, litter size, number of implanted embryos and embryonic, fetal and prenatal survival rates in a rabbit population selected for ten generations for ovulation rate.

2. To estimate direct response to selection for ovulation rate and correlated responses in litter size, number of implanted embryos and survival rates in the same rabbit line. Direct and correlated responses will be estimated by genetic trends and by comparison of the selected line with a vitrified control population. 



\title{
Chapter 3
}

\section{Selection for ovulation rate in rabbits: genetic parameters, direct response and correlated response on litter size.}

\author{
P. Laborda
}

${ }^{1}$ Instituto de Ciencia y Tecnología Animal, Universidad Politécnica de Valencia, 46071 Valencia. Spain; ${ }^{2}$ Departamento de Producción Animal y Ciencia y Tecnología de los Alimentos. Universidad Cardenal Herrera-CEU. Edificio Seminario. 46113 Moncada, Valencia. Spain.

J. Anim. Sci. 2011. 89:2981-2987

doi:10.2527/jas.2011-3906 



\section{Abstract}

The aim of this work was to evaluate the response to ten generations of selection for ovulation rate. Selection was based on phenotypic value of ovulation rate estimated at day 12 of second gestation by laparoscopy. Selection pressure was about 30\%. Line size was approximately 20 males and 80 females per generation. Traits recorded were: ovulation rate at second gestation (OR2), estimated by laparoscopy as the number of corpora lutea in both ovaries; ovulation rate at last gestation (ORS), estimated post mortem; ovulation rate (OR), analyzed as a single trait including OR2 and ORS; right and the left ovulation rates (ROR and LOR); ovulatory difference (OD), estimated as the difference between ROR and LOR; litter size (LS), estimated as total number of rabbits born and the number of kits born alive (NBA), both of them recorded at each parity. $A$ total of 1,477 and 3,031 records from 900 females were used to analyze OR and LS, respectively, while 1,471 records were used to analyze OD, ROR and LOR. Data were analyzed using Bayesian methodology. Heritabilities of OR, LS, NBA, ROR, LOR and OD were $0.16,0.09,0.08,0.09,0.04$ and 0.03 , respectively. Phenotypic correlations of OR with LS, NBA and OD were $0.09,0.01$ and 0.14 , respectively. Genetic correlations of OR with LS and with NBA were estimated with low accuracy and there was not much evidence of the sign of the correlation. The genetic correlation between OR and OD was positive $(P=0.91)$. In 10 generations of selection, $O R$ increased 1.3 ova, most of the response taking place in the right ovary (1.1 ova), but there was no correlated response on LS (-0.2 kits). In summary, direct response to selection for ovulation rate was relevant, but it did not modify litter size, due to an increase in prenatal mortality.

\section{Introduction}

Litter size is the most significant reproductive trait in polytocous species. It has a low heritability and response to selection has been consequently low. The response observed in rabbits, pigs and mice selected for litter size has been usually associated to an increment in the number of ova shed (Bolet et al., 1989 in pigs; Brun et al., 1992; Garcia and Baselga, 2002 in rabbits; Bakker et al., 1978; Gion et al., 1990 in mice).

Ovulation rate is, together with prenatal survival, the foremost component of litter size, being also a limiting factor for its improvement. Ovulation rate is correlated with 
litter size and it has a higher heritability (see review in Blasco et al., 1993b). For these reasons, selection for ovulation rate has been proposed to indirectly increase litter size (Zimmerman and Cunningham, 1975). There are several selection experiments for ovulation rate in pigs (Cunningham et al., 1979 and Rosendo et al., 2007) and mice (Land and Falconer, 1969 and Bradford, 1969), but, to our knowledge no selection for ovulation rate has hitherto been performed in rabbits. In these experiments, ovulation rate increased, but no correlated response in litter size occurred owing to a greater prenatal loss in the selected line.

In rabbits there is no embryo uterine transmigration (Adams, 1960) unlike in pigs. Rabbit does can have an overcrowded uterine horn, while the other one is less occupied. If ovulation rate increased with selection in both ovaries, females would be able to implant more embryos in the less occupied uterine horn, leading to a higher litter size.

The aim of this study is to evaluate direct response and correlated response in litter size in a rabbit line selected for ovulation rate for 10 generations.

\section{Materials and Methods}

\section{Animals}

All experimental procedures involving animals were approved by the Polytechnic University of Valencia Research Ethics Committee. Animals belonged to a rabbit line selected for ovulation rate for 10 generations. Then, selection was relaxed for 1 generation. This line derived from a synthetic line (V) selected for litter size at weaning for 12 generations (Estany et al., 1989), and then for high uterine capacity for 10 generations (Blasco et al., 2005). After that, selection was relaxed for 6 generations. Selection was based on the phenotypic value of ovulation rate estimated at day 12 of second gestation by laparoscopy. Selection pressure was about 30\% in females. Males were selected from litters of selected does within male families. The base population consisted of 85 females and 21 males. In the following generations the number of females and males was 75-30, 92-20, 80-15, 65-19, 59-16, 102-20, 80-13, 89-13, 65-13 and 108-29, respectively. Animals were housed at the experimental farm of the 
Universidad Politécnica de Valencia in individual cages. They were kept under controlled 16-h light: 8-h dark photoperiods and fed a commercial diet.

Traits

Ovulation rate at second gestation (OR2) was estimated as the number of corpora lutea in both ovaries by laparoscopy $(n=839)$. Ovulation rate at last gestation (ORS) was estimated post mortem at parities $3^{\text {rd }}(n=86), 4^{\text {th }}(n=115)$ and $5^{\text {th }}(n=437)$. Ovulation rate (OR) was also analyzed as a single trait including both ovulation rates (OR2 and ORS). Both ovulation rate in the right ovary (ROR) and ovulation rate in the left ovary (LOR) were measured. Ovulatory difference (OD) was estimated as the difference between ROR and LOR, expressed as an absolute value. Litter size (LS), measured as the total number of kits born per litter, and the number of kits born alive per litter (NBA) were measured in a maximum of 5 parities in each female. A total of 1,477 and 3,031 records from 900 females were used to analyze OR and LS, respectively, while 1,471 records were used to analyze OD, ROR and LOR.

\section{Statistical Analyses}

In order to estimate the heritabilities and the correlations between OR2 and ORS the following bivariate animal model was fitted:

$$
Y_{i j k}=Y S_{i}+L_{j}+a_{i j k}+e_{i j k}
$$

where $Y S_{i}$ is the effect of year-season (29 levels for OR2 and 27 levels for ORS), $L_{j}$ is the effect of lactation state of the doe (2 levels: multiparous lactating does and multiparous not lactating does when mated), $a_{i j k}$ is the additive value of the animal and $\mathrm{e}_{\mathrm{ijk}}$ is the residual of the model. The model assumed for ORS included also the parity effect $P$, with 3 levels.

Bayesian inference was used. Data augmentation was carried out in order to fill the data vector and have the same design matrices for all traits. Augmented data were not used for inferences, but permitted to simplify computing (Sorensen and Gianola, 2002). The traits were assumed to be conditionally normally distributed as follows:

$$
\left[\begin{array}{l}
\mathbf{y}_{1} \\
\mathbf{y}_{2}
\end{array}\right] \mid \mathbf{b}_{1}, \mathbf{b}_{2}, \mathbf{a}_{1}, \mathbf{a} 2, \mathbf{R} \sim N\left(X\left[\begin{array}{l}
b_{1} \\
b_{2}
\end{array}\right]+Z\left[\begin{array}{l}
a_{1} \\
a_{2}
\end{array}\right], R\right)
$$


where $\mathbf{b}_{\mathbf{1}}$ and $\mathbf{b}_{\mathbf{2}}$ were random vectors including the effects of $Y S, L$ and $P ; \mathbf{a}_{\mathbf{1}}$ and $\mathbf{a}_{\mathbf{2}}$ were vectors of individual additive genetic effects; $\mathbf{X}$ and $\mathbf{Z}$ were known incidence matrices; $\mathbf{R}$ was the residual (co)variance matrix. Between individuals only the additive random effects were assumed correlated. Within individuals and between traits, the additive and the residual effects were assumed correlated. The residual (co)-variance matrix can be written as $\mathbf{R}_{\mathbf{0}} \otimes \mathbf{I}_{\mathbf{n}}$ with $\mathbf{R}_{\mathbf{0}}$ being the $2 \times 2$ residual (co)variance matrix between the traits analyzed and $I_{n}$ an identity matrix of appropriate order. Bounded uniform priors were used to represent vague previous knowledge of $\mathbf{b}_{\mathbf{1}}$ and $\mathbf{b}_{\mathbf{2}}$. Prior knowledge concerning additive effects was represented by assuming that they were normally distributed, conditionally on the associated (co)variance components, as follows:

$$
\left[\begin{array}{l}
\mathbf{a}_{1} \\
\mathbf{a}_{2}
\end{array}\right] \mid \mathbf{G} \sim \mathbf{N}(\mathbf{0}, \mathbf{G})
$$

where $\mathbf{0}$ was a vector of zeroes and $\mathbf{G}$ was the genetic (co)variance matrix. This matrix could be written as $\mathbf{G}_{0} \otimes \mathbf{A}$, where $\mathbf{G}_{0}$ was the $2 \times 2$ genetic (co)variance matrix between the traits and $\mathbf{A}$ was the known additive genetic relationship matrix, including all the animals involved in the selection process and the parents of the base generation. Bounded uniform priors were used for the components of the (co)variance matrixes $\mathbf{R}_{\mathbf{0}}$ and $\mathbf{G}_{\mathbf{0}}$.

Bivariate repeatability animal models were fitted in order to estimate genetic parameters and genetic trends for OR, LS, NBA, OD, ROR and LOR. The model assumed was:

$$
y_{i j k l m n}=Y S_{i}+L_{j}+P_{k}+a_{l}+p_{m}+e_{i j k l m n}
$$

where $Y S_{i}$ has 32 levels for LS and NBA and 31 levels for OR, OD, ROR and LOR; $L_{j}$ has 2 levels; $P_{k}$ has 5 levels for LS and NBA and 4 levels for OR, OD, ROR and LOR and where $p_{i j k l}$ is the permanent environmental effect of the doe.

For the bivariate repeatability model, the traits were assumed to be conditionally normally distributed as follows: 


$$
\left[\begin{array}{l}
\mathbf{y}_{1} \\
\mathbf{y}_{2}
\end{array}\right] \mid \mathbf{b}_{1}, \mathbf{b}_{2}, \mathbf{a}_{1}, \mathbf{a}_{2}, \mathbf{p}_{1}, \mathbf{p}_{2}, \mathbf{R} \sim \mathbf{N}\left(\mathbf{X}\left[\begin{array}{l}
\mathbf{b}_{1} \\
\mathbf{b}_{2}
\end{array}\right]+\mathbf{Z}\left[\begin{array}{l}
\mathbf{a}_{1} \\
\mathbf{a}_{2}
\end{array}\right]+\mathbf{W}\left[\begin{array}{l}
\mathbf{p}_{1} \\
\mathbf{p}_{2}
\end{array}\right], \mathbf{R}\right)
$$

where $\mathbf{b}_{1}, \mathbf{b}_{2}, \mathbf{a}_{\mathbf{1}}$ and $\mathbf{a}_{\mathbf{2}}$ were distributed as before; $\mathbf{p}_{\mathbf{1}}$ and $\mathbf{p}_{\mathbf{2}}$ were vectors of permanent environmental effects and $\mathbf{W}$ was its known incidence matrix. As before, only the additive random effects were assumed correlated between individuals. Between traits, the additive, the permanent environmental and the residual effects were assumed correlated. Prior knowledge concerning permanent effects was represented by assuming that they were normally distributed, conditionally on the associated (co)variance components, as follows:

$$
\left[\begin{array}{l}
\mathbf{p}_{1} \\
\mathbf{p}_{2}
\end{array}\right] \mid \mathbf{P} \sim \mathbf{N}(\mathbf{0}, \mathbf{P})
$$

where $\mathbf{0}$ was a vector of zeroes and $\mathbf{P}$ was the (co)variance matrix of the non additive genetic plus permanent environmental effects of the doe. This matrix could be written as $\mathbf{P}_{\mathbf{0}} \otimes \mathbf{I}_{\mathbf{s}}$, where $\mathbf{P}_{\mathbf{0}}$ was the $2 \times 2$ permanent effects (co)variance matrix and $\mathbf{I}_{\mathbf{s}}$ the identity matrix of the same order as the number of levels of permanent effects. Bounded uniform priors were used for the components of the (co)variance matrix $\mathbf{P}_{\mathbf{0}}$. For trivariate repeatability analyses the order of $\mathbf{R}, \mathbf{G}$ and $\mathbf{P}$ matrices was $3 \times 3$.

Marginal posterior distributions of all unknowns were estimated by using the Gibbs sampling algorithm. The program TM by Legarra et al. (2008) was used for all Gibbs sampling procedures. Chains of 1,000,000 samples each were used, with a burning period of 200,000 . One sample each 50 was saved to avoid high correlations between consecutive samples. Convergence was tested using the $Z$ criterion of Geweke.

\section{Results and Discussion}

Means and standard deviations for all traits in generations 0 to 10 are presented in Table 1. Values are in agreement with the ones published by other authors in maternal rabbit lines (Brun et al., 1992; Piles et al., 2006; Theau-Clement, 2009). 
Table 1. Means and SD (in parenthesis) for ovulation rate at second gestation (OR2), ovulation rate at the last gestation (ORS), ovulation rate (OR), right ovulation rate (ROR), left ovulation rate (LOR), ovulatory difference (OD), litter size (LS) and number of kits born alive (NBA) in generations 0 to 10 .

\begin{tabular}{|c|c|c|c|c|c|c|c|c|c|c|c|}
\hline \multicolumn{12}{|c|}{ Generation } \\
\hline & 0 & 1 & 2 & 3 & 4 & 5 & 6 & 7 & 8 & 9 & 10 \\
\hline$S^{a}$ & 1.91 & 2.67 & 3.50 & 2.63 & 3.49 & 1.45 & 2.39 & 1.99 & 2.56 & 2.56 & - \\
\hline \multirow{2}{*}{ OR2 ${ }^{a}$} & 15.3 & 15.4 & 15.5 & 16.2 & 15.5 & 15.2 & 16.6 & 16.0 & 16.4 & 16.4 & 16.3 \\
\hline & $(2.1)$ & (2.5) & (2.5) & (2.5) & (3.0) & (2.3) & (2.2) & (2.1) & (2.4) & (2.5) & (2.6) \\
\hline \multirow{2}{*}{ ORS $^{a}$} & 14.3 & 15.4 & 16.0 & 16.7 & 16.0 & 15.9 & 15.8 & 15.2 & 15.0 & 14.8 & 16.5 \\
\hline & (2.3) & (2.9) & $(2.8)$ & (2.3) & (2.4) & $(2.6)$ & (2.4) & (2.5) & (2.4) & (2.1) & (2.4) \\
\hline \multirow{2}{*}{$\mathrm{OR}^{\mathrm{a}}$} & 14.9 & 15.5 & 15.8 & 16.4 & 15.8 & 15.5 & 16.3 & 15.7 & 15.9 & 15.8 & 16.4 \\
\hline & $(2.2)$ & (2.7) & (2.6) & (2.4) & (2.7) & (2.4) & (2.3) & (2.3) & (2.5) & (2.4) & (2.5) \\
\hline \multirow{2}{*}{ ROR $^{a}$} & 7.9 & 7.8 & 8.3 & 8.9 & 8.4 & 8.0 & 8.5 & 8.4 & 7.9 & 8.5 & 8.6 \\
\hline & (2.5) & (2.8) & (2.4) & (2.7) & (2.5) & (2.4) & (2.5) & (2.5) & (2.6) & (2.1) & (2.2) \\
\hline \multirow{2}{*}{ LOR $^{a}$} & 7.0 & 7.6 & 7.4 & 7.5 & 7.4 & 7.6 & 7.7 & 7.3 & 8.0 & 7.3 & 7.8 \\
\hline & $(2.2)$ & (2.7) & (2.4) & (2.6) & (2.2) & (2.3) & (2.2) & (2.6) & (2.3) & (2.1) & (2.4) \\
\hline \multirow{2}{*}{$O D^{a}$} & 3.5 & 4.0 & 3.4 & 3.8 & 3.2 & 3.3 & 3.2 & 3.7 & 3.4 & 2.9 & 3.1 \\
\hline & (2.6) & (2.6) & (2.3) & (3.0) & (2.3) & (3.7) & (2.7) & (2.8) & (2.5) & (2.3) & (2.4) \\
\hline \multirow{2}{*}{ LS $^{b}$} & 8.1 & 8.5 & 9.1 & 9.1 & 8.7 & 8.7 & 9.3 & 8.8 & 9.1 & 8.6 & 8.9 \\
\hline & (3.0) & (2.6) & (2.8) & (3.0) & (2.9) & (3.1) & (2.9) & (3.1) & (3.5) & (3.1) & (3.3) \\
\hline \multirow{2}{*}{ NBA $^{b}$} & 7.3 & 8.0 & 8.6 & 8.3 & 8.0 & 8.1 & 8.6 & 8.0 & 7.9 & 7.6 & 8.1 \\
\hline & (3.4) & (2.8) & (3.1) & (3.4) & (3.2) & (3.4) & (3.1) & (3.3) & (3.9) & (3.5) & (3.5) \\
\hline
\end{tabular}

S: Selection differential applied to animals at generation 0 and consecutively to the other generations.

${ }^{\mathrm{a}}$ Unit $=$ ova.

${ }^{\mathrm{b}}$ Unit $=$ kits.

\section{Ovulation rate}

The genetic correlation between OR2 and ORS was high and positive, with a probability of $95 \%$ of being higher than 0.87 (value k; Table 4). Thus, ovulation rate was analyzed as a single trait (OR), taking together both measures of ovulation rate, OR2 and ORS. Rosendo et al. (2007) obtained a similar genetic correlation in an experiment of selection for ovulation rate in pigs $\left(r_{\mathrm{g}}=0.89\right)$. 
Heritability estimate for OR was moderately low (0.16; Table 2), having a probability of $90 \%$ of being higher than 0.10 , and it was similar to other estimates obtained in intact rabbits by Blasco et al. (1993a) (0.21) and Bolet et al. (1994) (0.24). Our estimate was also consistent with the ones of Neal et al. (1989) (0.17) in pigs and Long et al. (1991) (0.18) in a combined data set of intact and unilaterally ovariectomized mice. However, other estimates published in pigs and mice were higher; in pigs, Cunningham et al. (1979) and Rosendo et al. (2007) obtained heritabilities for OR of 0.33 and 0.42 . In mice, Land and Falconer (1969) had a realized heritabilitiy of 0.31 .

Table 2. Features of the marginal posterior distributions of the heritability for ovulation rate at second gestation (OR2), ovulation rate at the last gestation (ORS), ovulation rate (OR), right ovulation rate (ROR), left ovulation rate (LOR), ovulatory difference (OD), litter size (LS) and number of kits born alive (NBA).

\begin{tabular}{lccccc}
\hline \hline Traits & mean & median & HPD $_{95 \%}$ & $\mathbf{P}_{0.10}$ & $\mathbf{k}$ \\
\hline OR2 & 0.23 & 0.23 & $0.10,0.36$ & 0.98 & 0.12 \\
ORS & 0.27 & 0.26 & $0.15,0.38$ & 1.00 & 0.17 \\
OR & 0.16 & 0.16 & $0.07,0.25$ & 0.90 & 0.08 \\
ROR & 0.09 & 0.09 & $0.04,0.15$ & 0.40 & 0.05 \\
LOR & 0.04 & 0.04 & $0.00,0.09$ & 0.02 & 0.01 \\
OD & 0.03 & 0.03 & $0.00,0.07$ & 0.01 & 0.01 \\
LS & 0.09 & 0.08 & $0.03,0.14$ & 0.29 & 0.04 \\
NBA & 0.08 & 0.08 & $0.03,0.14$ & 0.26 & 0.04
\end{tabular}

HPD $_{95 \%}$ : high posterior density interval at $95 \%$. $\mathrm{P}_{0.10}$ : probability of the heritability being higher than 0.10 . $k$ : limit for the interval $[k,+\infty)$ having a probability of $95 \%$.

Right ovulation rate and LOR had lower heritability estimates than OR, being higher for ROR than for LOR (0.09 and 0.04, respectively; Table 2) The probability of this difference being higher than zero is $87 \%$ (data not shown). In rabbits, Blasco et al. (1993a) obtained heritability estimates for ROR and LOR of 0.22 and 0.10, respectively, but the estimates had large standard errors. Nielsen et al. (1996) in mice and Rosendo et al. (2007) in pigs observed different heritability estimates for the right and the left ovary, this time in favor of the left side. Right ovulation rate and LOR had a moderate and negative phenotypic correlation (high posterior density interval at 95\% [-0.56, - 
0.41]; Table 3) but the genetic correlation between them was moderately low and positive ( $P=0.79$; Table 4). This difference in the sign of the correlation was also observed in mice by Clutter et al. (1990) $\left(r_{p}=-0.51 ; r_{g}=0.72\right)$ and in pigs by Haley and Lee (1992) $\left(r_{p}=-0.52 ; r_{g}=0.94\right)$ and Rosendo et al. (2007) $\left(r_{p}=-0.30 ; r_{g}=0.99\right)$. In order to explain the negative phenotypic correlation $\left(r_{p}\right)$ between ROR and LOR, Haley and Lee (1992) suggested a negative feedback mechanism between the ovaries. Blasco et al. (1993a) did not observe differences in the sign of the correlation, being both negative, however the genetic correlations in both studies in rabbits were estimated with low accuracy.

Table 3. Features of the marginal posterior distributions of the phenotypic correlations between the traits analyzed: ovulation rate at second gestation (OR2), ovulation rate the last gestation (ORS), ovulation rate (OR), right ovulation rate (ROR), left ovulation rate (LOR), ovulatory difference (OD), litter size (LS) and number of kits born alive (NBA).

\begin{tabular}{lcccccc}
\hline \hline Traits & mean & median & HPD $_{95 \%}$ & HPD $_{90 \%}$ & $\mathbf{P}$ & $\mathbf{k}$ \\
\hline OR2, ORS & 0.23 & 0.23 & $0.16,0.31$ & $0.17,0.30$ & $1.00^{\mathrm{a}}$ & $0.17^{\mathrm{a}}$ \\
OR, ROR & 0.51 & 0.51 & $0.44,0.57$ & $0.45,0.57$ & $1.00^{\mathrm{a}}$ & $0.45^{\mathrm{a}}$ \\
OR, LOR & 0.40 & 0.40 & $0.33,0.48$ & $0.34,0.47$ & $1.00^{\mathrm{a}}$ & $0.34^{\mathrm{a}}$ \\
ROR, LOR & -0.49 & -0.49 & $-0.56,-0.41$ & $-0.54,-0.42$ & $1.00^{\mathrm{b}}$ & $-0.55^{\mathrm{b}}$ \\
OR, OD & 0.14 & 0.14 & $0.06,0.22$ & $0.08,0.21$ & $1.00^{\mathrm{a}}$ & $0.07^{\mathrm{a}}$ \\
OR, LS & 0.09 & 0.09 & $0.00,0.17$ & $0.02,0.17$ & $0.98^{\mathrm{a}}$ & $0.02^{\mathrm{a}}$ \\
OR, NBA & 0.01 & 0.01 & $-0.08,0.10$ & $-0.07,0.08$ & $0.59^{\mathrm{a}}$ & $-0.07^{\mathrm{a}}$
\end{tabular}

$\mathrm{HPD}_{95 \%}$ : high posterior density interval at $95 \% ; \mathrm{HPD}_{90 \%}$ : high posterior density interval at $90 \%$; $\mathrm{P}$ : probability of the phenotypic correlation being greater than zero (superscript a), or less than zero (superscript b); $k$ : limit for the interval $[k,+\infty)$ (superscript a), or $(-\infty, k]$ (superscript b), having a probability of $95 \%$.

In rabbits, unlike pigs, there is no embryo uterine transmigration (Adams, 1960). Thus, there is no compensatory effect between uterine horns, and ovulatory difference is associated to uneven fetal distribution through both uterine horns. This could lead to overcrowding of one uterine horn and to higher mortality rate on that side, while the other uterine horn remains less occupied being unable to express its uterine capacity. Ovulatory difference had a low heritability (0.03) and it was phenotypically and genetically positively correlated with OR (Tables 2, 3 and 4). The genetic correlation 
was moderate, with a probability of $91 \%$ of being positive. The phenotypic correlation was low and it was positive. These positive correlations indicate that females with high ovulation rate tend to have more ovulatory difference and thus their prenatal mortality could increase.

Table 4. Features of the marginal posterior distributions of the genetic correlations between the traits analyzed: ovulation rate at second gestation (OR2), ovulation rate at the last gestation (ORS), ovulation rate (OR), right ovulation rate (ROR), left ovulation rate (LOR), ovulatory difference (OD), litter size (LS) and number of kits born alive (NBA).

\begin{tabular}{lcccccc}
\hline \hline Traits & mean & median & HPD $_{95 \%}$ & HPD $_{90 \%}$ & $\mathbf{P}$ & $\mathbf{k}$ \\
\hline OR2, ORS & 0.96 & 0.98 & $0.87,1.00$ & $0.90,1.00$ & $1.00^{\mathrm{a}}$ & $0.87^{\mathrm{a}}$ \\
OR, ROR & 0.93 & 0.96 & $0.77,1.00$ & $0.82,1.00$ & $1.00^{\mathrm{a}}$ & $0.77^{\mathrm{a}}$ \\
OR, LOR & 0.72 & 0.77 & $0.23,1.00$ & $0.38,1.00$ & $0.98^{\mathrm{a}}$ & $0.23^{\mathrm{a}}$ \\
ROR, LOR & 0.38 & 0.40 & $-0.35,1.00$ & $-0.21,1.00$ & $0.79^{\mathrm{a}}$ & $-0.35^{\mathrm{a}}$ \\
OR, OD & 0.55 & 0.64 & $-0.18,1.00$ & $0.02,1.00$ & $0.91^{\mathrm{a}}$ & $-0.18^{\mathrm{a}}$ \\
OR, LS & -0.20 & -0.19 & $-0.77,0.30$ & $-0.63,0.26$ & $0.76^{\mathrm{b}}$ & $0.23^{\mathrm{b}}$ \\
OR, NBA & -0.29 & -0.27 & $-0.99,0.18$ & $-0.80,0.21$ & $0.84^{\mathrm{b}}$ & $0.17^{\mathrm{b}}$
\end{tabular}

$\mathrm{HPD}_{95 \%}$ : high posterior density interval at $95 \%$; $\mathrm{HPD}_{90 \%}$ : high posterior density interval at $90 \%$; P: probability of the genetic correlation being greater than zero (superscript a), or less than zero (superscript b); $k$ : limit for the interval $[k,+\infty)$ (superscript a), or $(-\infty, k]$ (superscript b), having a probability of $95 \%$.

\section{Litter size}

Heritability estimates for LS and for NBA were low (0.09 and 0.08, respectively; Table 2). These estimates are similar to other estimates reported in rabbits (Blasco, 1996; García and Baselga, 2002), pigs (review in Pérez-Enciso, 1997; Canario et al., 2006) and mice (Clutter et al., 1990). The phenotypic correlation between OR and LS was positive $(P=98 \%$, Table 3$)$ but low, having a probability of $99 \%$ of being lower than 0.30 . The phenotypic correlation between OR and NBA was almost zero, with a probability of $96 \%$ of being in the interval $[-0.10,0.10]$. The genetic correlation of OR with LS has a large high posterior density interval at $95 \%([-0.77,0.30]$, Table 4$)$. Hence, there was not much evidence about the sign of the correlation. Other estimates of genetic correlations between OR and LS in intact females were higher and positive (Blasco et 
al., 1993a (0.36) in rabbits; Johnson et al., 1999 (0.24) and Rosendo et al., 2007 (0.41) in pigs; Clutter et al., 1990 (0.81) and Long et al., 1991 (0.62) in mice), although the range of the standard errors for the genetic correlations was wide for all of them. However, based in our estimates, we cannot sustain that selection for ovulation rate will improve litter size.

\section{Response to selection}

The response to selection for ovulation rate and the correlated responses in ROR, LOR, OD, LS and NBA are shown in Figures 1 and 2. After 10 generations of selection, ovulation rate increased in 1.3 ova, near $1 \%$ per generation ( 0.13 ova /generation); Most of the response took place in the right ovary; ROR and LOR increased in 1.1 and 0.5 ova, respectively. Ovulatory difference increased 0.3 ova in 10 generations; however the increase in OD seems to be due to a scale effect related to the increase of the mean of OR. This was corroborated after analyzing OD fitting OR as a covariate ( $b$ OR OD $=0.08)$, where no response to selection was observed. Direct response in ovulation rate has been relevant, but lower than expected, although selection differential was relatively high, between 1.75 and 3.50 throughout the experiment (Table 1).
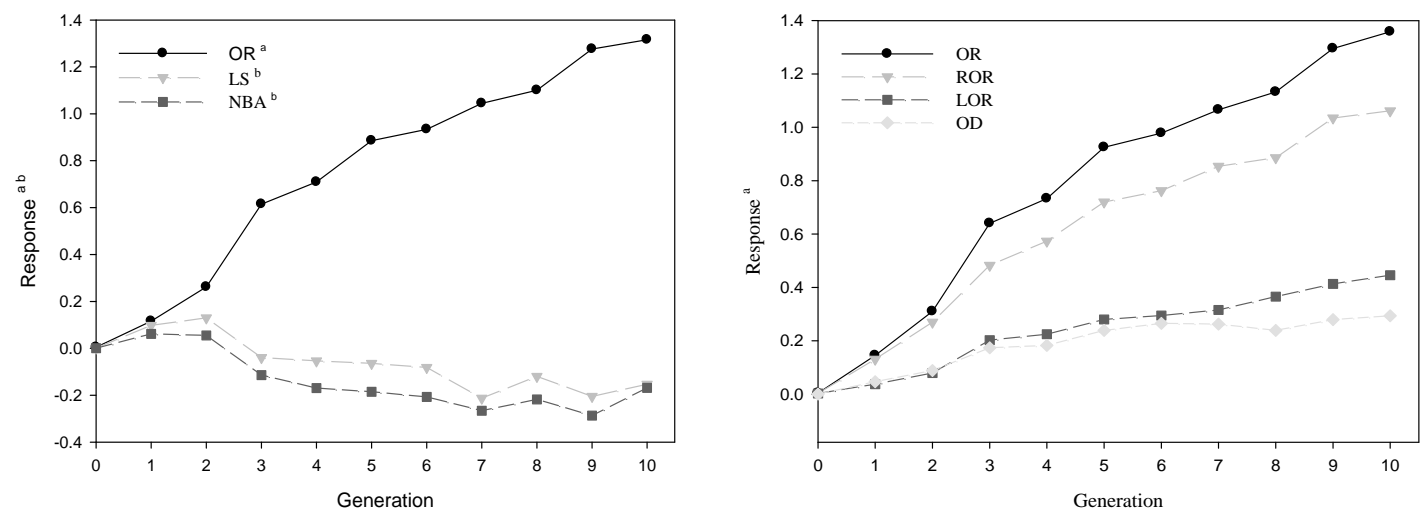

Figures 1 and 2: Genetic trends for ovulation rate (OR), litter size (LS) and number of kits born alive (NBA) (Figure 1). Genetic trends for ovulation rate (OR), right ovulation rate (ROR), left ovulation rate (LOR) and ovulatory difference (OD) (Figure 2).

${ }^{\mathrm{a}}$ Unit $=$ ova; ${ }^{\mathrm{b}}$ Unit $=$ kits. 
In pigs, Cunningham et al. (1979) and Rosendo et al. (2007) obtained higher responses (3.7 ova in 9 generations and approximately 2 ova in 7 generations, respectively). In rabbits, response in litter size after direct selection has been usually close to $1 \%$ per generation (see review in Mocé and Santacreu, 2010). In our study, selection for ovulation rate has not modified litter size; correlated responses in LS and NBA were not relevant ( -0.2 total born and -0.2 kits born alive in 10 generations). Possible causes for the lacking correlated response in LS will be discussed below.

Selection for ovulation rate was proposed as a promising way of indirectly increasing litter size. As Pérez-Enciso and Bidanel (1997) showed in their review, when selection was carried out for LS in rabbits, pigs and mice, changes were basically due to an increase in OR. Conversely, when selection was performed on OR, correlated response on LS was close to zero (in pigs: Cunningham et al., 1979; Rosendo et al., 2007; in mice: Bradford, 1969; Land and Falconer, 1969). In the present study, a positive correlated response in LS was expected, because in rabbits there is no uterine transmigration. If OR increased in both ovaries, the ovary with higher ovulation rate would already have its uterine horn overcrowded; but the ovary with less ovulation rate would shed more ova able to implant, therefore the number of implanted embryos would possibly increase as an average and that would possibly lead to a higher litter size. However, a not correlated response in LS and in NBA was observed; thus, prenatal mortality should have increased. A possible explanation for our results would be ovulation of immature oocytes. It is possible that some oocytes are released in an early state, not having acquired developmental competence, in agreement with Koenig et al. (1986), who suggested that selection for high ovulation rate could induce ovulation of immature oocytes. Another explanation could be the ovulatory timing, which lasts about 14 hours in rabbits (Fujimoto et al., 1974). In females with extremely high ovulation rates, the duration of the ovulatory process could increase. Pope et al. (1988) described differences in ovulatory timing affecting early embryonic development in pigs: $68 \%$ of the follicles ovulated simultaneously in a short period of time, while the remaining ruptured later. These late ovulated oocytes were fertilized later and became small and less competent blastocysts, which were more susceptible to die (Xie et al., 1990). A third explanation for our results would be a decrease in fetal 
survival due to an asynchrony between the development of fetus and maternal uterus or due to a higher fetal competence for space and nutrients in overcrowded uterine horns.

\section{Implications}

Our results show that ovulation rate responded to selection but no correlated response on litter size was found. There are possible explanations for the lacking correlated response observed in litter size; these include poor quality oocytes, high variability in embryonic development or competence among fetuses after implantation. Further analyses are needed in order to elucidate whether embryonic mortality or fetal mortality are responsible for the lacking correlated response on litter size.

\section{Literature cited}

Adams, C. E. 1960. Prenatal mortality in the rabbit Oryctolagus cuniculus. J. Reprod. Fertil. 1:36-44.

Bakker, H., J. H. Wallinga, and R. D. Politiek. 1978. Reproduction and body weight of mice after long-term selection for large litter size. J. Anim. Sci. 46:1572-1580.

Blasco, A., M. A. Santacreu, R. Thompson, and C. Haley. 1993a. Estimates of genetic parameters for ovulation rate, prenatal survival and litter size in rabbits from an elliptical selection experiment. Livest. Prod. Sci. 34:163-174.

Blasco, A., J. P. Bidanel, G. Bolet, C. Haley, and M. A. Santacreu. 1993b. The genetics of prenatal survival of pigs and rabbits, a review. Livest. Prod. Sci. 37:1-21.

Blasco, A. 1996. Genetics of litter size and does fertility in the rabbit. Proc. 6th World Congr. Cuniculture, Toulouse, France 2:219-228.

Blasco, A., J. A. Ortega, M. A. Santacreu, and A. Climent. 2005. Divergent selection for uterine capacity in rabbits. I. Genetic parameters and response to selection. J. Anim. Sci. 83:2297-2302. 
Bolet, G., L. Ollivier, and P. Dando. 1989. Sélection sur la prolificité chez le porc. I. Résultats d’une expérience de sélection sur onze générations. Genet. Sel. Evol. 21:93-106.

Bolet, G., M. A. Santacreu, M. J. Argente, A. Climent, and A. Blasco. 1994. Divergent selection for uterine efficiency in unilaterally ovariectomized rabbits. I. Phenotypic and genetic parameters. Proc. 5th World Congr. Genet. Appl. Livest. Prod. 19:261-264.

Bradford, G. E. 1969. Genetic control of ovulation rate and embryo survival in mice. I. Response to selection. Genetics 61:907-918.

Brun, J. M., G. Bolet, and J. Ouhayoun. 1992. The effects of crossbreeding and selection on productive and reproductive traits in a triallel experiment between three strains of rabbits. J. Appl. Rabbit Res. 15:181-189.

Canario, L., N. Roy, J. Gruand, and J. P. Bidanel. 2006. Genetic variation of farrowing kinetics traits and relationships with litter size and perinatal mortality in French Large White sows. J. Anim. Sci. 84:1053-1058.

Clutter, A. C., M. K. Nielsen, and R. K. Johnson. 1990. Alternative methods of selection for litter size in mice: I. Characterization of base population and development of methods. J. Anim. Sci. 68:3536-3542.

Cunningham, P. J., M. E. England, L. D. Young, and D. R. Zimmerman. 1979. Selection for ovulation rate in swine: Correlated response in litter size and weight. J. Anim. Sci. 48:509-516.

Estany, J., M. Baselga, A. Blasco, and J. Camacho. 1989. Mixed model methodology for the estimation of genetic response to reproductive traits to weaning in rabbits, improving selection in litter size of rabbits. Livest. Prod. Sci. 21:67-75.

Fujimoto, S., J. M. R. Rawson, and W. R. Dukelow. 1974. Hormonal influences on the time of ovulation in the rabbit as determined by laparoscopy. J. Reprod. Fertil. 38:97-103.

García, M. L., and M. Baselga. 2002. Estimation of genetic response to selection in litter size of rabbits using a cryopreserved control population. Livest. Prod. Sci. 74:4553. 
Gion, J. M., A. C. Clutter, and M. K. Nielsen. 1990. Alternative methods of selection for litter size in mice: II. Response to thirteen generations of selection. J. Anim. Sci. 68:3543-3556.

Haley, C. S., and G. J. Lee. 1992. Genetic factors contributing to variation in litter size in British Large White gilts. Livest. Prod. Sci. 30:99-113.

Johnson, R. K., D. R. Zimmerman, and R. J. Kittok. 1984. Selection for components of reproduction in swine. Livest. Prod. Sci. 11:541-558.

Johnson, R. K., M. K. Nielsen, and D. S. Casey. 1999. Responses in ovulation rate, embryonal survival and litter traits in swine to 14 generations of selection to increase litter size. J. Anim. Sci. 77:541-557.

Koenig, J. L. F., D. R. Zimmerman, F. E. Eldrige, and J. D. Kopf. 1986. The effect of superovulation and selection for high ovulation rate on chromosomal abnormalities in swine ova. J. Anim. Sci. 63(Suppl.1):202 (Abstr.).

Land, R. B., and D. S. Falconer. 1969. Genetic studies of ovulation rate in the mouse. Genet. Res. 13:25-46.

Legarra, A., L. Varona, and E. López de Maturana. 2008. Program TM. http://snp.toulouse.inra.fr/ alegarra/.

Long, C. R., W. R. Lamberson, and R. O. Bates. 1991. Genetic correlations among reproductive traits and uterine dimensions in mice. J. Anim. Sci. 69:99-103.

Mocé, M. L., and M. A. Santacreu. 2010. Genetic improvement of litter size in rabbits: a review. CD-Proc. 9th World Congr. Genet. Appl. Livest. Prod. Leipzig, Germany.

Neal, S. M., R. K. Johnson, and R. J. Kittok. 1989. Index selection for components of litter size in swine: Response to five generations of selection. J. Anim. Sci. 67:1933-1945.

Nielsen, M. K., Y. L. Kirby, and A. C. Clutter. 1996. Estimates of heritabilities and genetic and environmental correlations for left- and right-side uterine capacity and ovulation rate in mice. J. Anim Sci. 74:529-534.

Pérez-Enciso, M., and J. P. Bidanel. 1997. Selection for litter size components. A critical review. Genet. Sel. Evol. 29:483-496. 
Piles, M., E. A. Gómez, O. Rafel, J. Ramon, and A. Blasco. 2006. Elliptical selection experiment for the estimation of genetic parameters of the growth rate and feed conversion ratio in rabbits. J. Anim. Sci. 84:2309-2315.

Pope, W. F., M. H. Wilde, and S. Xie. 1988. Effect of electrocautery of nonovulated day 1 follicles on subsequent morphological variation among day 11 porcine embryos. Biol. Reprod. 39:882-887.

Rosendo, A., T. Druet, J. Gogué, and J. P. Bidanel. 2007. Direct responses to six generations of selection for ovulation rate or prenatal survival in Large White pigs. J. Anim. Sci. 85:356-364.

Sorensen, D., and D. Gianola. 2002. Likelihood, Bayesian, and MCMC Methods in Quantitative Genetics. Springer, New York, NY.

Theau-Clement, M., P. Salvetti, G. Bolet, G. Saleil, and T. Joly. 2009. Influence de l'intervalle entre le sevrage et l'insemination sur la production d'embryons et leur qualité chez la lapine. 13émes Journées de la Recherche Cunicole, INRAITAVI, Le Mans, France. Pages 125-128.

Xie, S., D. M. Broermann, K. P. Nephew, R. D. Geisert, and W. F. Pope. 1990. Ovulation and Early Embryogenesis in Swine. Biol. Reprod. 43:236-240.

Zimmerman, D. R., and P. J. Cunningham. 1975. Selection for ovulation rate in swine: population, procedures and ovulation response. J. Anim. Sci. 40:61-69. 



\title{
Chapter 4
}

\section{Selection for ovulation rate in rabbits: genetic parameters and correlated responses on survival rates.}

\author{
P. Laborda ${ }^{1}$, M. L. Mocé ${ }^{1,2}$, A. Blasco ${ }^{1}$ and M. A. Santacreu ${ }^{1}$
}

\footnotetext{
${ }^{1}$ Instituto de Ciencia y Tecnología Animal, Universidad Politécnica de Valencia, 46071 Valencia. Spain; ${ }^{2}$ Departamento de Producción Animal y Ciencia y Tecnología de los Alimentos. Universidad Cardenal Herrera-CEU. Edificio Seminario. 46113 Moncada, Valencia. Spain.
}

J. Anim. Sci. published online September 16, 2011 doi:10.2527/jas.2011-4219 



\section{Abstract}

The aim of this work was to evaluate the correlated responses on survival rates after ten generations of selection for ovulation rate. Selection was based on the phenotypic value of ovulation rate estimated at $\mathrm{d} 12$ of second gestation by laparoscopy. Traits recorded were: litter size (LS), estimated as total number of rabbits born per litter in up to five parities; ovulation rate $(O R)$, estimated as the number of corpora lutea in both ovaries; the number of implanted embryos (IE), estimated as the number of implantation sites; the number of right and left implanted embryos (RIE and LIE); ovulatory difference (OD), defined as the difference between the right and the left ovulation rate, expressed as an absolute value; implantatory difference (ID), defined as the difference between RIE and LIE, expressed as an absolute value; embryonic survival (ES), calculated as IE/OR; fetal survival (FS), calculated as LS/IE; prenatal survival (PS), calculated as LS/OR. A total of 1,081 records were used to analyze ES and 770 were used to analyze FS and PS. The number of records used to analyze the other traits ranged from 1,079 for ID to 3,031 for LS. Data were analyzed using Bayesian methodology. Genetic parameters of $O R, O D$ and LS were estimated in a previous paper. Estimated heritabilities of IE, ID, ES, FS and PS were $0.11,0.03,0.09,0.24$ and 0.14, respectively. Estimated repeatabilities of IE, ID and ES were 0.22, 0.12 and 0.20. Estimated phenotypic correlations of OR with ES, FS and PS were $-0.07,-0.26$ and 0.28 , respectively. Their estimated genetic correlations with FS and PS were negative (probability of being negative 1.00 and 0.98 , respectively). Nothing can be said about the sign of the genetic correlation between $O R$ and ES. Ovulation rate was phenotypically uncorrelated with ID. Their estimated genetic correlation was positive (probability of being positive 0.91). The estimated genetic correlations of ID with PS and LS were imprecise. Phenotypic and genetic correlations between LS and survival rates were positive (probability of being positive 1.00). In 10 generations of selection, FS decreased around 1\% per generation. No correlated response in ES was observed. In summary, the decrease in fetal survival in rabbits selected for ovulation rate seemed to be responsible for the lack of correlated response observed in litter size. 


\section{Introduction}

Selection for ovulation rate has been proposed as an indirect way of increasing litter size (Zimmerman and Cunningham, 1975); ovulation rate is the upper limit of litter size and it has a higher heritability. Laborda et al. (2010) have shown that selection for ovulation rate has been successful in rabbits, but there has been no correlated response in litter size. The same phenomenon has been observed in the experiments of selection for ovulation rate in pigs (Cunningham et al., 1979; Rosendo et al., 2007; Leymaster and Christenson, 2000) and mice (Land and Falconer, 1969; Bradford, 1969). In these selection experiments, the lacking correlated response in litter size was associated to an increase in prenatal mortality. There is little information about the timing of prenatal mortality in experiments of selection for ovulation rate in pigs and mice, due to the difficulties in measuring the number of fetuses without altering litter size. In mice, Bradford (1969) observed that most prenatal mortality occurred after implantation. In pigs, the main difference in prenatal mortality in a line selected for ovulation rate was observed during the early fetal development between d 25 and 45 of gestation (Freking et al., 2007). This difference was associated to less endometrial space for the fetuses at implantation in the selected females. Although pigs and mice have a different uterine architecture and different types of placentation, fetal survival has decreased with selection for ovulation rate in both species.

In rabbits, unlike pigs and mice, it is possible to easily measure the number of implanted embryos by laparoscopy in live females, and thus it is possible to calculate embryonic and fetal survival in the same doe, without altering litter size (Santacreu et al., 1990). The aim of this study was to evaluate the correlated responses on embryonic, fetal and prenatal survival in a rabbit line selected for ovulation rate during 10 generations.

\section{Material and methods}

\section{Animals}

All experimental procedures involving animals were approved by the Polytechnic University of Valencia Research Ethics Committee. Animals belonged to a 10 
generation selection experiment for ovulation rate, described in a companion paper by Laborda et al. (2011), which began in February 2002 and continued until February 2010. Selection was based on the phenotypic value of ovulation rate estimated at day 12 of second gestation by laparoscopy. Implantation in rabbits takes place at $\mathrm{d} 7$ and laparoscopy permits to count implantation sites at d 12 (Santacreu et al. 1990).

Traits

Litter size (LS) was measured as the total number of kits born per litter; it was measured in a maximum of 5 parities in each female. Ovulation rate (OR), estimated as the number of corpora lutea in both ovaries, and the number of implanted embryos (IE), estimated as the number of implantation sites, were measured by laparoscopy at d 12 of second gestation. Both the number of implanted embryos in the right (RIE) and the left uterine horn (LIE) were measured. Ovulatory difference (OD) was defined as the difference between the ovulation rates in the right and the left ovaries, expressed as an absolute value; implantatory difference (ID), was defined as the difference between RIE and LIE, expressed as an absolute value. Embryonic survival (ES) was calculated as IE/OR, fetal survival (FS) was calculated as LS/IE and prenatal survival (PS) was calculated as LS/OR. Females from all generations had a second post mortem measurement of OR and OD; further, females from the $1^{\text {st }}$ to the $5^{\text {th }}$ generation had a second post mortem measurement of IE, RIE, LIE, ID and ES.

A total of 3,031 and 1,477 records from 900 females were used to analyze LS and OR, respectively, while 1,081 records were used to analyze IE and ES. A total of 1,471 records were used for OD, 1,079 for ID, RIE and LIE and 770 for FS and PS. The number of animals in the pedigree was 1107.

\section{Statistical Analyses}

Bayesian inference was used. Data augmentation was carried out to fill the data vector and have the same design matrices for all traits. Augmented data were not used for inferences, but permitted to simplify computing (Sorensen and Gianola, 2002). Bivariate and trivariate repeatability animal models were fitted to estimate genetic parameters and genetic trends. Ovulation rate was included in each analysis, both bivariates and trivariates. Correlations with OR were estimated using bivariate models. 
Trivariate analyses were used to estimate genetic parameters between traits different from OR. The model assumed for OR, OD, LS, IE, RIE, LIE, ID and ES was:

$$
Y_{i j k l m n}=Y S_{i}+L_{j}+P_{k}+a_{l}+p_{m}+e_{i j k l m n}
$$

where $\mathrm{YS}_{\mathrm{i}}$ is the effect of year-season (one year season every three months: 32 levels for LS, 31 levels for OR and OD, 30 levels for IE, RIE, LIE, ID and ES), $L_{j}$ is the effect of lactation state of the doe ( 2 levels: 1 for lactating and 2 for not lactating does when mated), $P_{k}$ is the effect of parity ( 5 levels for LS, 4 levels for the other traits), $a_{1}$ is the additive value of the animal, $p_{m}$ is the permanent environmental effect of the doe and $\mathrm{e}_{\mathrm{ijk} k \mathrm{mn}}$ is the residual of the model. The model for FS and PS did neither have the parity effect nor the permanent environmental effect, because records came only from the second parity, and the year-season effect had 30 levels.

For the bivariate repeatability model, the traits were assumed to be conditionally normally distributed as follows:

$$
\left[\begin{array}{l}
y_{1} \\
y_{2}
\end{array}\right] \mid b_{1}, b_{2}, a_{1}, a_{2}, p_{1}, p_{2}, R \sim N\left(X\left[\begin{array}{l}
b_{1} \\
b_{2}
\end{array}\right]+Z\left[\begin{array}{l}
a_{1} \\
a_{2}
\end{array}\right]+W\left[\begin{array}{l}
p_{1} \\
p_{2}
\end{array}\right], R\right)
$$

where $\boldsymbol{b}_{1}$ and $\boldsymbol{b}_{2}$ were random vectors including the effects of $Y S, L$ and $P ; \boldsymbol{a}_{1}$ and $\boldsymbol{a}_{\boldsymbol{2}}$ were vectors of individual additive genetic effects; $\boldsymbol{p}_{1}$ and $\boldsymbol{p}_{2}$ were vectors of permanent environmental effects. $\boldsymbol{X}, \boldsymbol{Z}$ and $\boldsymbol{W}$ were known incidence matrices; $\boldsymbol{R}$ was the residual (co)variance matrix. Between individuals, only the additive random effects were assumed correlated. Between traits, the additive, the permanent environmental and the residual effects were assumed correlated. The residual (co)variance matrix can be written as $\boldsymbol{R}_{\boldsymbol{0}} \otimes \boldsymbol{I}_{\boldsymbol{n}}$, with $\boldsymbol{R}_{\boldsymbol{0}}$ being the $2 \times 2$ residual (co)variance matrix between the traits analyzed and $I_{n}$ an identity matrix of appropriate order. Bounded uniform priors were used to represent vague previous knowledge of distributions of $\boldsymbol{b}_{\mathbf{1}}$ and $\boldsymbol{b}_{\mathbf{2}}$. Prior knowledge concerning additive and permanent effects was represented by assuming that they were normally distributed, conditionally on the associated (co)variance components, as follows:

$$
\left[\begin{array}{l}
a_{1} \\
a_{2}
\end{array}\right]\left|G \sim N(\mathbf{0}, G) \quad\left[\begin{array}{l}
p_{1} \\
p_{2}
\end{array}\right]\right| P \sim N(\mathbf{0}, P)
$$


where $\mathbf{0}$ was a vector of zeroes, $\mathbf{G}$ was the genetic (co)variance matrix and $\mathbf{P}$ was the (co)variance matrix of the non additive genetic plus permanent environmental effects of the doe. Matrices $\boldsymbol{G}$ and $\boldsymbol{P}$ could be written as $\boldsymbol{G}_{\boldsymbol{0}} \otimes \boldsymbol{A}$ and $\boldsymbol{P}_{\boldsymbol{0}} \otimes \boldsymbol{I}_{\boldsymbol{s}}$, respectively, where $\boldsymbol{G}_{\boldsymbol{0}}$ and $\boldsymbol{P}_{\boldsymbol{0}}$ were the $2 \times 2$ genetic and permanent (co)variance matrices, $\boldsymbol{A}$ was the known additive genetic relationship matrix and $I_{s}$ the identity matrix of the same order as the number of levels of permanent effects. Bounded uniform priors were used for the components of the (co)variance matrices $\boldsymbol{R}_{\boldsymbol{0}}$ and $\boldsymbol{G}_{\boldsymbol{0}}$ and $\boldsymbol{P}_{\boldsymbol{0}}$. For trivariate repeatability analyses the order of $\boldsymbol{R}, \boldsymbol{G}$ and $\boldsymbol{P}$ matrices was $3 \times 3$.

Marginal posterior distributions of all unknowns were estimated by using the Gibbs sampling algorithm. The programs TM by Legarra et al. (2008) and GIBBS2F90 by Misztal et al. (2002) were used for all Gibbs sampling procedures. Chains of 1,000,000 samples each were used, with a burning period of 200,000 . One sample each 50 was saved to avoid high correlations between consecutive samples. Convergence was tested using the $Z$ criterion of Geweke.

\section{Results and discussion}

Means and standard deviations of the traits IE, RIE, LIE, ID and survival rates in the base generation are presented in Table 1; values of IE and survival rates are in agreement with values published by other authors in maternal rabbit lines (Brun et al., 1992; García and Baselga, 2002). Means and standard deviations for OR, OD and LS can be found in Laborda et al. (2011).

Table 1. Means and SD for number of implanted embryos (IE), number of implanted embryos on the right and on the left uterine horn (RIE and LIE), implantatory difference (ID=|RIE-LIE $\mid$ ), embryonic survival (ES), fetal survival (FS) and prenatal survival (PS) in the base generation.

\begin{tabular}{lccccccc}
\hline \hline Trait & IE & RIE & LIE & ID & ES & FS & PS \\
\hline mean & 12.5 & 6.6 & 5.9 & 3.2 & 0.82 & 0.73 & 0.59 \\
SD & 3.2 & 2.6 & 2.5 & 2.5 & 0.18 & 0.19 & 0.20 \\
\hline
\end{tabular}


In our experiment, prenatal mortality (1-PS) expressed as a percentage was approximately $40 \%$ in the base generation, in agreement with results previously reported in rabbits (Adams, 1960a,b), 18\% corresponding to the embryonic period (preimplantation), and $22 \%$ to the fetal period (postimplantation). In pigs, a prenatal loss of $40 \%$ to $60 \%$ has been reported (reviewed by Foxcroft at al., 2006); most of it has been observed before $\mathrm{d}$ 30-35 of gestation. Prenatal mortality in mice is around 20\% (Bradford, 1969; Clutter et al., 1990). This percentage is almost equally distributed between the pre- and the postimplantation period (reviewed by Wilmut et al., 1986).

In our experiment, we have differentiated between pre- and postimplantation mortality (1-ES and 1-FS, respectively). This difference was not applied in most selection experiments involving ovulation rate in pigs and mice. Thus, comparisons with our data have to be taken with caution. In pigs, fetuses cannot be individualized by observation of its external surface by laparoscopy; therefore, the number of fetuses was counted in vivo by laparotomy at $d 50$, which in this species corresponds to the middle gestation, reducing fetal survival and litter size (Neal et al., 1989; Johnson et al., 1999). In mice, the number of fetuses was measured after slaughtering the female near the end of gestation ( $d$ 17, Clutter et al., 1990) or at $d$ 7-8 and d 16 of gestation (Bradford, 1969).

The features of the marginal posterior distributions of the heritabilities of IE, RIE, LIE, ID and survival rates and the repeatabilities of IE, RIE, LIE, ID and ES are shown in Table 2. Heritabilities of OR $\left(0.16\right.$ HPD $\left._{95 \%}[0.07,0.25]\right)$, OD $\left(0.03 ; H^{-} D_{95 \%}[0.00,0.07]\right)$ and LS (0.09; HPD $95 \%$ [0.03, 0.14]) were presented in Laborda et al. (2011). Their repeatabilities were $0.25\left(\mathrm{HPD}_{95 \%}[0.17,0.32]\right), 0.09\left(\mathrm{HPD}_{95 \%}[0.03,0.15]\right)$ and 0.19 $\left(\mathrm{HPD}_{95 \%}[0.15,0.23]\right)$, respectively. Tables 3 and 4 present the features of the marginal posterior distributions of the phenotypic correlations between traits, and Tables 5 and 6 present the features of the marginal posterior distributions of the genetic correlations between traits. In general, genetic correlations were estimated with low accuracy, and often it was only possible to draw conclusions about their sign. 


\section{Number of implanted embryos}

The IE had a low heritability (Table 2). This was of the same magnitude as heritability of IE in rabbits (Bolet et al., 1994; Argente et al., 2000) and heritabilities of the number of fetuses at different moments of gestation in rabbits (d 12), pigs (d 50) and mice (d 17) (Blasco et al., 1993a; Johnson et al., 1999; Clutter et al., 1990, respectively). The estimated phenotypic correlation of IE with OR (Table 3 ) had similar magnitude and sign than the ones obtained in these species. The posterior mean of the genetic correlation between IE and OR had a large HPD $95 \%$ interval (Table 5), but it was positive with a high probability $(P=0.99)$. Our result is in accordance with the ones obtained in pigs and mice, where a positive genetic correlation between IE and OR was estimated: 0.44 in pigs (Johnson et al., 1999) and 0.81 in mice (Clutter et al., 1990). Both estimates were also imprecise. The repeatability estimate of IE was 0.22 with $\mathrm{HPD}_{95 \%}[0.13,0.31]$ (Table 2). This repeatability estimate leads to an estimated ratio of the permanent environmental variance to the phenotypic variance $\left(p^{2}\right)$ of 0.11 . No repeatability or $p^{2}$ estimates of the traits IE, ID or ES have been found in the literature. However, our estimate of $p^{2}$ is within the range reported in the literature for litter size in rabbits (reviewed by Garreau et al., 2004).

Table 2. Features of the marginal posterior distributions of the heritability $\left(h^{2}\right)$ and the repeatability ( $r$ ) of number of implanted embryos (IE), number of implanted embryos on the right and on the left uterine horn (RIE and LIE), implantatory difference (ID=|RIE-LIE $\mid$ ), and embryonic survival (ES) and the heritability of fetal survival (FS) and prenatal survival (PS).

\begin{tabular}{llllllc}
\hline \hline Traits & $\mathbf{h}^{2}$ & HPD $_{95 \%}\left(\mathbf{h}^{2}\right)$ & $\mathbf{P}_{\mathbf{0 . 1 0}}$ & $\mathbf{k}$ & $\mathbf{r}$ & HPD $_{95 \%}(\mathbf{r})$ \\
\hline IE & 0.11 & $0.04,0.19$ & 0.58 & 0.05 & 0.22 & $0.13,0.31$ \\
RIE & 0.08 & $0.01,0.14$ & 0.24 & 0.03 & 0.22 & $0.11,0.31$ \\
LIE & 0.06 & $0.01,0.13$ & 0.13 & 0.02 & 0.14 & $0.05,0.23$ \\
ID & 0.03 & $0.00,0.08$ & 0.01 & 0.01 & 0.12 & $0.05,0.20$ \\
ES & 0.09 & $0.02,0.17$ & 0.39 & 0.04 & 0.20 & $0.11,0.29$ \\
FS & 0.24 & $0.10,0.38$ & 0.98 & 0.13 & - & - \\
PS & 0.14 & $0.04,0.25$ & 0.75 & 0.06 & - & - \\
\hline
\end{tabular}

$\mathrm{HPD}_{95 \%}$ : high posterior density interval at $95 \%$. $\mathrm{P}_{0.10}$ : probability of the heritability being higher than $0.10 . \mathrm{k}$ : limit for the interval $[k,+\infty)$ of the heritability having a probability of $95 \%$. 
Estimated phenotypic and genetic correlations between LS and IE were 0.57 (Table 4) and 0.46 (Table 6). Their probabilities of being positive were $100 \%$ and $98 \%$, respectively. Similar phenotypic correlations but apparently higher genetic correlations were obtained in rabbits and pigs, possibly because the number of fetuses was measured at a later point of gestation (Blasco et al., 1993a in rabbits; Johnson et al., 1999 in pigs) or because genetic correlations were estimated with low accuracy.

Taking all together, IE is not a good candidate to improve LS by indirect selection, due to its low heritability (Table 2 ) and its moderately low genetic correlation with litter size (Table 6).

Table 3. Features of the marginal posterior distributions of the phenotypic correlation between the traits analyzed: ovulation rate $(O R)$, ovulatory difference $(O D)$, number of implanted embryos (IE), number of implanted embryos on the right and on the left uterine horn (RIE and LIE), implantatory difference (ID=|RIE-LIE $\mid)$, embryonic survival $(E S)$, fetal survival (FS) and prenatal survival (PS).

\begin{tabular}{lllll}
\hline Traits & mean & HPD $_{95 \%}$ & $\mathbf{P}$ & $\mathbf{k}$ \\
\hline IE, OR & 0.38 & $0.29,0.47$ & $1.00^{\mathrm{a}}$ & $0.30^{\mathrm{a}}$ \\
RIE, OR & 0.28 & $0.19,0.38$ & $1.00^{\mathrm{a}}$ & $0.20^{\mathrm{a}}$ \\
LIE, OR & 0.30 & $0.20,0.38$ & $1.00^{\mathrm{a}}$ & $0.22^{\mathrm{a}}$ \\
ID, OR & 0.00 & $-0.08,0.09$ & $0.55^{\mathrm{a}}$ & $-0.07^{\mathrm{a}}$ \\
ES, OR & -0.07 & $-0.17,0.03$ & $0.92^{\mathrm{b}}$ & $-0.15^{\mathrm{b}}$ \\
FS, OR & -0.26 & $-0.33,-0.19$ & $1.00^{\mathrm{b}}$ & $-0.20^{\mathrm{b}}$ \\
PS, OR & -0.28 & $-0.35,-0.21$ & $1.00^{\mathrm{b}}$ & $-0.22^{\mathrm{b}}$ \\
ID, OD & 0.59 & $0.51,0.65$ & $1.00^{\mathrm{a}}$ & $0.53^{\mathrm{a}}$ \\
RIE, LIE & -0.04 & $-0.12,0.04$ & $0.83^{\mathrm{b}}$ & $0.03^{\mathrm{b}}$ \\
\hline
\end{tabular}

$\mathrm{HPD}_{95 \%}$ : high posterior density interval at 95\%; P: probability of the phenotypic correlation being greater than zero (superscript a), or less than zero (superscript b); $k$ : limit for the interval $[k,+\infty)$ (superscript a), or $(-\infty, k]$ (superscript b), having a probability of $95 \%$.

The number of right and left implanted embryos had low heritabilities (0.08 and 0.06 for RIE and LIE, respectively; Table 2), in accordance with the ones obtained by Blasco et al. (1993a). In mice, different results were obtained: Clutter et al. (1990) showed 
different heritability estimates for the number of fetuses in the right and the left uterine horns at $d 17$ of gestation, being higher for the right side than for the left side ( 0.18 and 0.03 , respectively). In our study, the phenotypic and the genetic correlations of OR with RIE and LIE were positive with a high probability ( $P \geq 87 \%$; Tables 3 and 5 ), indicating that RIE and LIE tend to increase with selection for OR. The phenotypic correlation between RIE and LIE was very low (Table 3), whereas the genetic correlation was positive with a high probability ( $\mathrm{P}=96 \%$; Table 5$)$. In mice, the estimate of the phenotypic correlation between fetuses in the right and left uterine horn was close to zero $(-0.01)$, and the estimated genetic correlation between them was imprecise (Clutter et al., 1990).

Table 4. Features of the marginal posterior distributions of the phenotypic correlation between the traits analyzed: litter size (LS), number of implanted embryos (IE), implantatory difference (ID=|RIE-LIE $\mid$ ), embryonic survival (ES), fetal survival (FS) and prenatal survival (PS).

\begin{tabular}{lcccc}
\hline \hline Traits & mean & HPD $_{95 \%}$ & $\mathbf{P}$ & $\mathbf{k}$ \\
\hline IE, LS & 0.57 & $0.51,0.62$ & $1.00^{\mathrm{a}}$ & $0.52^{\mathrm{a}}$ \\
ID, LS & 0.00 & $-0.09,0.09$ & $0.53^{\mathrm{a}}$ & $-0.08^{\mathrm{a}}$ \\
ES, LS & 0.52 & $0.47,0.59$ & $1.00^{\mathrm{a}}$ & $0.48^{\mathrm{a}}$ \\
FS, LS & 0.56 & $0.52,0.60$ & $1.00^{\mathrm{a}}$ & $0.53^{\mathrm{a}}$ \\
PS, LS & 0.89 & $0.88,0.90$ & $1.00^{\mathrm{a}}$ & $0.88^{\mathrm{a}}$ \\
ID, PS & -0.06 & $-0.13,0.02$ & $0.93^{\mathrm{b}}$ & $0.00^{\mathrm{b}}$ \\
ES, FS & -0.07 & $-0.15,0.01$ & $0.96^{\mathrm{b}}$ & $0.00^{\mathrm{b}}$ \\
\hline
\end{tabular}

$\mathrm{HPD}_{95 \%}$ : high posterior density interval at $95 \%$; $\mathrm{P}$ : probability of the phenotypic correlation being greater than zero (superscript a), or less than zero (superscript b); $k$ : limit for the interval $[k,+\infty)$ (superscript a), or $(-\infty, k]$ (superscript b), having a probability of $95 \%$.

Implantatory difference (ID) refers to uneven embryo distribution through both uterine horns, where one uterine horn remains less occupied than the other one. Implantatory difference had a close to zero heritability, having only a probability of $1 \%$ of being higher than $0.10\left(\mathrm{P}_{0.10}\right.$; Table 2$)$. As there is no embryo uterine transmigration in rabbits (Adams, 1960b), ID may be associated to ovulatory difference (OD). The 
estimate of the phenotypic correlation between OD and ID was 0.59 , having a probability of $95 \%$ of being at least 0.53 (Table 3). The genetic correlation was positive $(P=0.92 ;$ Table 5). These positive correlations suggest that $O D$ and ID may increase together. Implantatory difference was phenotypically uncorrelated with OR (Table 3). However, the genetic correlation with OR was positive with a probability of 91\% (Table $5)$, indicating that ID could increase with OR. These different phenotypic and genetic correlations are due to a negative permanent environmental correlation between the OR and ID (-0.50; HPD $95 \%[-1.00,0.29])$. Implantatory difference was suggested by Laborda et al. (2011) to cause higher prenatal mortality in overcrowded uterine horns, contributing to the lacking correlated response in LS in rabbits selected for ovulation rate. However, this hypothesis could not be tested, because the phenotypic correlations of ID with PS and LS were close to zero (Tables 4) and the genetic correlations were estimated with low accuracy (Table 6).

Table 5. Features of the marginal posterior distributions of the genetic correlation between the traits analyzed: ovulation rate (OR), number of implanted embryos (IE), number of implanted embryos on the right and on the left uterine horn (RIE and LIE), implantatory difference (ID=|RIE-LIE $\mid)$, embryonic survival (ES), fetal survival (FS) and prenatal survival (PS).

\begin{tabular}{lcccc}
\hline \hline Traits & mean & HPD $_{95 \%}$ & $\mathbf{P}$ & $\mathbf{k}$ \\
\hline IE, OR & 0.58 & $0.16,0.93$ & $0.99^{\mathrm{a}}$ & $0.20^{\mathrm{a}}$ \\
RIE, OR & 0.74 & $0.33,1.00$ & $0.99^{\mathrm{a}}$ & $0.33^{\mathrm{a}}$ \\
LIE, OR & 0.41 & $-0.29,1.00$ & $0.87^{\mathrm{a}}$ & $-0.29^{\mathrm{a}}$ \\
ID, OR & 0.56 & $-0.17,1.00$ & $0.91^{\mathrm{a}}$ & $-0.17^{\mathrm{a}}$ \\
ES, OR & 0.02 & $-0.57,0.64$ & $0.53^{\mathrm{a}}$ & $-0.49^{\mathrm{a}}$ \\
FS, OR & -0.58 & $-1.00,-0.26$ & $1.00^{\mathrm{b}}$ & $-0.26^{\mathrm{b}}$ \\
PS, OR & -0.55 & $-1.00,-0.11$ & $0.98^{\mathrm{b}}$ & $-0.11^{\mathrm{b}}$ \\
ID, OD & 0.69 & $-0.33,1.00$ & $0.92^{\mathrm{a}}$ & $-0.33^{\mathrm{a}}$ \\
RIE, LIE & 0.44 & $-0.03,0.89$ & $0.96^{\mathrm{a}}$ & $0.01^{\mathrm{a}}$
\end{tabular}

$\mathrm{HPD}_{95 \%}$ : high posterior density interval at 95\%; P: probability of the genetic correlation being greater than zero (superscript a), or less than zero (superscript b); $k$ : limit for the interval $[k,+\infty)$ (superscript a), or $(-\infty, k]$ (superscript b), having a probability of $95 \%$. 


\section{Survival rates}

Heritabilities were low for ES and PS (Table 2). Heritability of FS was moderate, with a probability of $98 \%$ of being higher than 0.10 (Table 2). Heritability estimates were similar to the estimates presented by Blasco et al. (1993a) in rabbits. The heritability estimate of PS also agrees with the estimates in pigs (Rosendo et al., 2007) and mice (Clutter et al., 1990). Estimated phenotypic correlations between OR and survival rates were negative with a probability of at least 92\% (Table 3); however, they were of low magnitude, especially the phenotypic correlation between OR and ES that had a probability near $100 \%$ of being in the interval from -0.20 to 0.20 . The estimated genetic correlation between OR and ES was imprecise and nothing can be said about its sign (Table 5). The estimated genetic correlation of OR with FS was negative, having a probability of $95 \%$ of being lower than -0.26 (k, Table 5). The genetic correlation of OR with PS was negative, too ( $P=98 \%$; Table 5$)$. In previous studies in rabbits and pigs, correlations between ovulation rate and prenatal survival ranged from -0.14 to -0.45 (Blasco et al., 1993a in rabbits; Rosendo et al., 2007 in pigs). In mice, the genetic correlation between ovulation rate and survival at $d 17$ of gestation was low, but it was estimated with low accuracy (Clutter et al., 1990). Phenotypic and genetic correlations of ovulation rate with the components of prenatal survival, embryonic and fetal survival, are scarce in the literature. Our results agree with the ones published previously in rabbits (Blasco et al., 1993a). In pigs, Neal et al. (1989) had a negative genetic correlation $(-0.56)$, estimated with a high standard error, between ovulation rate and survival at $d 50$ in a line selected for an index of these two traits during 5 generations. Johnson et al. (1999) obtained a high and negative genetic correlation $(-0.86)$ in the same line of pigs after 11 generations of selection for the same index followed by 3 generations of selection for litter size.

Litter size was positively correlated with ES, FS and PS, being phenotypic and genetic correlations of similar magnitude (Tables 4 and 6). Genetic correlations were moderate with ES and FS and high with PS, which had a probability of $95 \%$ of being at least 0.85 . The genetic correlation of LS with ES and FS had probabilities of $89 \%$ and $91 \%$ of being higher than 0.5 . The positive correlations between LS and survival rates agree with the 
estimates found in the literature (Blasco et al., 1993b for a review; Blasco et al., 1993a in rabbits; Johnson et al., 1999 and Rosendo et al., 2007 in pigs).

The moderate heritability of FS together with its positive and moderately high genetic correlation with LS, convert FS into an interesting trait to select for in rabbits, being a better candidate than OR. No selection experiment for FS has been found in the literature. In rabbits, there is one experiment of selection for the number of dead fetuses from implantation until birth in unilateral ovariectomized females (Bolet et al., 1994). This trait had a very low heritability and variability, and no correlated response in litter size was observed.

Table 6. Features of the marginal posterior distributions of the genetic correlation between the traits analyzed: litter size (LS), number of implanted embryos (IE), implantatory difference (ID=|RIE-LIE $\mid)$, embryonic survival (ES), fetal survival (FS) and prenatal survival (PS).

\begin{tabular}{lcccc}
\hline \hline Traits & mean & HPD $_{95 \%}$ & $\mathbf{P}$ & $\mathbf{k}$ \\
\hline IE, LS & 0.46 & $0.06,0.78$ & $0.98^{\mathrm{a}}$ & $0.12^{\mathrm{a}}$ \\
ID, LS & 0.05 & $-0.60,0.69$ & $0.57^{\mathrm{a}}$ & $-0.53^{\mathrm{a}}$ \\
ES, LS & 0.69 & $0.39,0.94$ & $1.00^{\mathrm{a}}$ & $0.40^{\mathrm{a}}$ \\
FS, LS & 0.65 & $0.39,0.90$ & $1.00^{\mathrm{a}}$ & $0.41^{\mathrm{a}}$ \\
PS, LS & 0.91 & $0.85,0.97$ & $1.00^{\mathrm{a}}$ & $0.85^{\mathrm{a}}$ \\
ID, PS & -0.15 & $-0.86,0.53$ & $0.65^{\mathrm{b}}$ & $0.49^{\mathrm{b}}$ \\
ES, FS & 0.02 & $-0.55,0.59$ & $0.53^{\mathrm{a}}$ & $-0.46^{\mathrm{a}}$ \\
\hline
\end{tabular}

$\mathrm{HPD}_{95 \%}$ : high posterior density interval at $95 \%$; $\mathrm{P}$ : probability of the genetic correlation being greater than zero (superscript a), or less than zero (superscript b); $k$ : limit for the interval $[k,+\infty)$ (superscript a), or $(-\infty, k]$ (superscript b), having a probability of $95 \%$.

\section{Response to selection}

The response to selection for OR (1.3 ova in 10 generations) and the correlated responses in OD ( 0.3 ova in 10 generations) and in LS (-0.2 kits in 10 generations) were already presented in a previous paper (Laborda et al., 2011). The correlated responses in IE, RIE, LIE, ID and survival rates are shown in Figures 1 and 2. After 10 generations of selection, the correlated response in IE was 0.9 embryos, most of it taking place in 
the right side ( 0.8 embryos). The low response in ID (0.1 embryo), less than $0.5 \%$ per generation, was apparently not responsible for the lacking correlated response in LS (Laborda et al. 2011). Moreover, the small increase in ID seems to be due to a scale effect related to the increase in IE, similar to what happens with OD (Laborda et al., 2011). This was confirmed after analyzing ID fitting IE as a covariate, where no response to selection was observed (-0.036 in 10 generations).
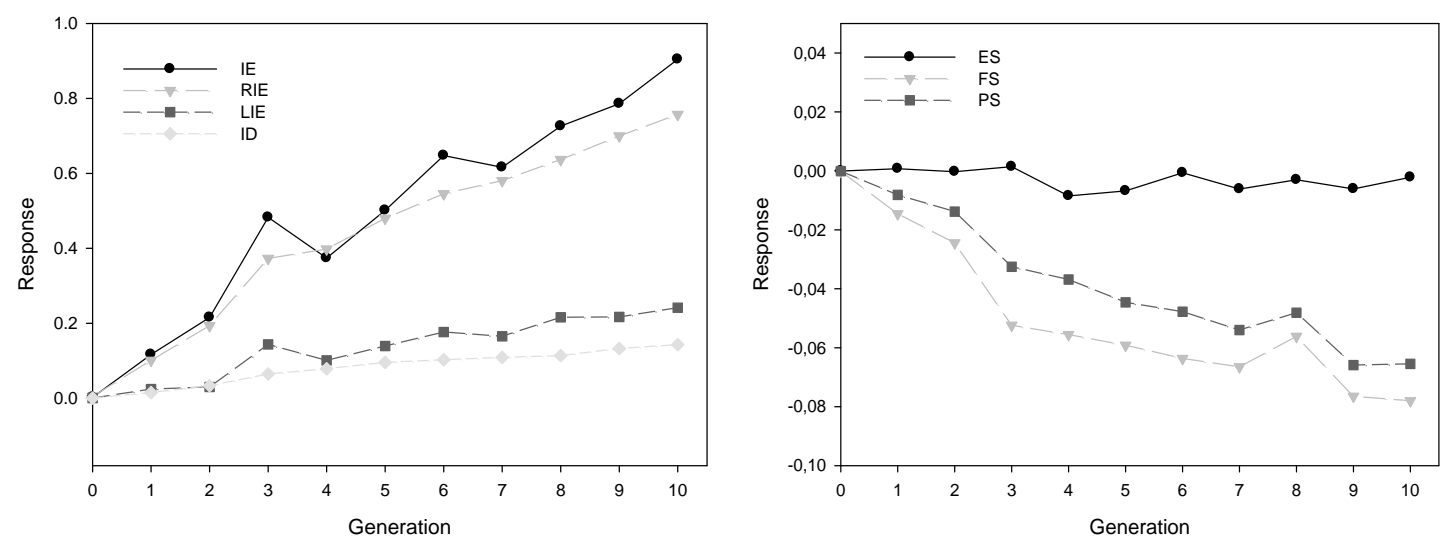

Figures 1 and 2: Genetic trends for number of implanted embryos (IE), right and left implanted embryos (RIE and LIE) and implantatory difference (ID=|RIE-LIE $\mid$ ). Unit=embryos (Fig. 1). Genetic trends for embryonic survival (ES), fetal survival (FS) and prenatal survival (PS) (Fig. 2).

To our knowledge, this is the first experiment of selection for ovulation rate where the responses in the two components of prenatal survival have been studied in the same animal, since in pigs and mice fetuses cannot be easily counted in vivo without increasing their mortality. In our experiment, PS decreased 0.07 in 10 generations, around $1 \%$ per generation. Leymaster and Christenson (2000) obtained a similar response in a line of pigs selected for ovulation rate for 11 generations. We did not observe any response in ES, but FS decreased 0.08 in 10 generations, around 1\% per generation. Thus, this decrease in FS was responsible for the lack of correlated response observed in LS. As in this experiment, Freking et al. (2007) did not observe any changes in embryonic survival in unilateral hysterectomy-ovariectomy females in the line of pigs described by Leymaster and Christenson (2000); the main changes were observed during the early fetal development between days 25 and 45 of gestation 
associated to less endometrial space for the fetuses at implantation in the overcrowded uterine horns. Similarly, Bradford (1969) observed that postimplantation losses were the main cause for the uncorrelated response in litter size in the line selected for ovulation rate by comparing it with a control line and a line selected for litter size.

Most prenatal mortality in rabbits selected for ovulation rate occured during the fetal period. A critical moment for fetal survival in rabbits is between $\mathrm{d} 8$ and 17 of gestation, when the development of the placenta takes place (Adams, 1960a,b; Hafez, 1966). Placental development in rabbits, as in mice, has been associated to the number of blood vessels arriving to the implantation site (Duncan, 1969; Argente et al., 2003; Mocé et al., 2004 in rabbits; Wirth-Dzieciolowska, 1987 in mice). Fetuses and fetal placentas are more developed when they receive more blood vessels, while fetuses with poor blood supply have a higher probability to die. In females with extremely high OR and overcrowded uterine horns, the blood flow to each fetus could be reduced, decreasing their survival.

Other explanations for the decreased FS could be immature oocytes or less developed embryos, which would not be able to survive in later states of gestation. The proportion of females with extremely high OR (more than 20 ova; i.e., twice the standard deviation over the mean) increased with selection from $4 \%$ to $23 \%$. These females could ovulate immature oocytes. A higher proportion of immature ova in pig females selected for ovulation rate compared to females from a control line was found by Koenig et al. (1986), who suggested that prenatal mortality could increase due to this, either before or after implantation. On the other hand, as follicles ovulate sequentially (Fujimoto et al., 1974), in females with high ovulation rate the ovulatory process could take longer than usual. A long ovulatory duration could lead to an increased variability in embryonic development (Torres et al., 1984). In rabbits, pigs and mice, it was observed that the uterine environment was synchronic with the more developed embryos, which had a better chance to survive (Torres et al., 1984 in rabbits; Pope, 1988 and Xie at al., 1990 in pigs; Wilmut et al., 1986 and Al-Shorepy et al., 1992 in mice). Lesser developed embryos have been related to a lower embryonic and fetal survival in rabbits (Mocé et al., 2004 and Peiró et al., 2007 in rabbits). In pigs, 
it has been demonstrated that lesser-developed embryos were able to survive beyond implantation (Wilde et al., 1988; Pope et al., 1990); however they would probably die soon after that due to fetal competence for space, contributing to the decrease in fetal survival (Geisert and Schmitt, 2002).

In conclusion, the results show that selection for ovulation rate has increased fetal mortality, while embryo mortality does not seem to have been modified. This fetal mortality has been the main cause for the lacking correlated response observed in litter size. Some possible explanations would be a decreased blood flow arriving to each fetus or even immature oocytes or less developed embryos that die after implantation. Further studies are needed to explain the mechanism that has caused fetal mortality in rabbits selected for high ovulation rate.

\section{Literature cited}

Adams, C. E. 1960a. Prenatal mortality in the rabbit Oryctolagus cuniculus. J. Reprod. Fertil. 1:36-44.

Adams, C. E. 1960b. Studies on prenatal mortality in the rabbit, Oryctolagus cuniculus: The amount and distribution of loss before and after implantation. J. Endocrinol. 19:325-344.

Argente, M. J., M. Santacreu, A. Climent, and A. Blasco. 2000. Genetic correlation between litter size and uterine capacity. 7th World Rabbit Congress. ValenciaEspaña B:333-338.

Argente, M. J., A. Blasco, J. A. Ortega, C. S. Haley, and P. M. Visscher. 2003. Analyses for the presence of a major gene affecting uterine capacity in unilaterally ovariectomized rabbits. Genetics 163:1061-1068.

Al-Shorepy, S. A., A. C. Clutter, R. M. Blair, and M. K. Nielsen. 1992. Effects of three methods of selection for litter size in mice on pre-implantation embryonic development. Biol. Reprod. 46: 958-963. 
Blasco, A., M. A. Santacreu, R. Thompson, and C. Haley. 1993a. Estimates of genetic parameters for ovulation rate, prenatal survival and litter size in rabbits from an elliptical selection experiment. Livest. Prod. Sci. 34:163-174.

Blasco, A., J. P. Bidanel, G. Bolet, C. Haley, and M. A. Santacreu. 1993b. The genetics of prenatal survival of pigs and rabbits, a review. Livest. Prod. Sci. 37:1-21.

Bolet, G., M. A. Santacreu, M. J. Argente, A. Climent, and A. Blasco.1994. Divergent selection for uterine efficiency in unilaterally ovariectomized rabbits. I. Phenotypic and genetic parameters. Proc. 5th World Congr. Genet. Appl. Livest. Prod., Guelph, Ontario, Canada 19:261-264.

Bradford, G. E. 1969. Genetic control of ovulation rate and embryo survival in mice. I. Response to selection. Genetics 61:907-918.

Brun, J. M., G. Bolet, and J. Ouhayoun. 1992. The effects of crossbreeding and selection on productive and reproductive traits in a triallel experiment between three strains of rabbits. J. Appl. Rabbit Res. 15:181-189.

Clutter, A. C., M. K. Nielsen, and R. K. Johnson. 1990. Alternative methods of selection for litter size in mice: I. Characterization of base population and development of methods. J. Anim. Sci. 68:3536-3542.

Cunningham, P. J., M. E. England, L. D. Young, and D. R. Zimmerman. 1979. Selection for ovulation rate in swine: Correlated response in litter size and weight. J. Anim. Sci. 48:509-516.

Duncan, S. L. B. 1969. The partition of uterine blood flow in the pregnant rabbit. J. Physiol. (Lond.) 204:421-433.

Freking, B. A., K. A. Leymaster, J. L. Vallet, and R. K. Christenson. 2007. Number of fetuses and conceptus growth throughout gestation in lines of pigs selected for ovulation rate or uterine capacity. J. Anim. Sci. 85:2093-2103.

Foxcroft, G. R., W. T. Dixon, S. Novak, C. T. Putman, S. C. Town, and M. D. Vinsky. 2006. The biological basis for prenatal programming of postnatal performance in pigs. J. Anim. Sci. 84(Suppl): E105-E112. 
Fujimoto, S., J. M. R. Rawson, and W. R. Dukelow. 1974. Hormonal influences on the time of ovulation in the rabbit as determined by laparoscopy. J. Reprod. Fertil. 38:97-103.

García, M. L., and M. Baselga. 2002. Estimation of genetic response to selection in litter size of rabbits using a cryopreserved control population. Livest. Prod. Sci. 74:4553.

Garreau, H., M. Piles, C. Larzul, M. Baselga, and H. Rochambeau. 2004. Selection of maternal lines: Last results and prospects. Proc. 8th World Rabbit Congress, Puebla, Mexico 14-25.

Geisert, R. D., and R. A. M. Schmitt. 2002. Early embryonic survival in the pig: Can it be improved? J. Anim. Sci. 80(E-Suppl.): E54-E65.

Hafez E.S.E., and Y. Tsutsumi. 1966. Changes in endometrial vascularity during implantation and pregnancy in the rabbit. Am. J. Anat. 118:249-82.

Johnson, R. K., M. K. Nielsen, and D. S. Casey. 1999. Responses in ovulation rate, embryonal survival and litter traits in swine to 14 generations of selection to increase litter size. J. Anim. Sci. 77:541-557.

Koenig, J. L. F., D. R. Zimmerman, F. E. Eldrige, and J. D. Kopf. 1986. The effect of superovulation and selection for high ovulation rate on chromosomal abnormalities in swine ova. J. Anim. Sci. 63(Suppl.1):202 (Abstr.).

Laborda, P., M. L. Mocé, M. A. Santacreu, and A. Blasco. 2011. Selection for ovulation rate in rabbits: I. genetic parameters, direct response and correlated response on litter size. J. Anim. Sci. 89:2981-2987.

Land, R. B., and D. S. Falconer. 1969. Genetic studies of ovulation rate in the mouse. Genet. Res. 13:25-46.

Legarra, A., L. Varona, and E. López de Maturana. 2008. Program TM. http://snp.toulouse.inra.fr/ alegarra/.

Leymaster, K. A., and R. K. Christenson. 2000. Direct and correlated responses to selection for ovulation rate or uterine capacity in swine. J. Anim. Sci. 78(Suppl. 1):68. (Abstr.) 
Misztal, I., S. Tsuruta, T. Strabel, B. Auvray, T. Druet, and D. H. Lee. 2002. BLUPF90 and related programs (BGF90). Proc. 7th World Congr. Genet. Appl. Livest. Prod., Montpellier, France 28:07.

Mocé, M. L., M. A. Santacreu, A. Climent, and A. Blasco. 2004. The effect of divergent selection for uterine capacity on prenatal survival in rabbits: Maternal and embryonic genetic effects. J. Anim. Sci. 82:68-73.

Neal, S. M., R. K. Johnson, and R. J. Kittok. 1989. Index selection for components of litter size in swine: Response to five generations of selection. J. Anim. Sci. 67:1933-1945.

Peiró, R., M. A. Santacreu, A. Climent, and A. Blasco. 2007. Early embryonic survival and embryo development in two divergent lines selected for uterine capacity. J. Anim. Sci. 85:1634-1639.

Pope, W. F. 1988. Uterine Asynchrony: A cause of embryonic loss. Biol. Reprod. 39:999-1003.

Pope, W. F., S. Xie, D. M. Broermann, and K. P. Nephew. 1990. Causes and consequences of early embryonic diversity in pigs. J. Reprod. Fertil. 40:251-260.

Rosendo, A., T. Druet, J. Gogué, and J. P. Bidanel. 2007. Direct responses to six generations of selection for ovulation rate or prenatal survival in Large White pigs. J. Anim. Sci. 85:356-364.

Santacreu, M. A., M. P. Viudes, and A. Blasco. 1990. Evaluation par coelioscopie des corps jaunes et des embryons. Influence sur la taille de portee chez la lapine. Reprod. Nutr. Dev. 30:583-588.

Sorensen, D., and D. Gianola. 2002. Likelihood, bayesian, and MCMC methods in quantitative genetics. Springer, New York, NY.

Torres, S., F. Hulot, and M. Meunier. 1984. Étude comparée du développement et de la mortalité embryonnaire chez deux genotypes de lapines. 3rd World Rabbit Congress. Rome-Italy 2:417-425. 
Wilde, M. H., S. Xie, M. L. Day, and W. F. Pope. 1988. Survival of small and large littermate blastocysts in swine after synchronous and asynchronous transfer procedures. Theriogenology 30:1069-1074.

Wilmut I., D. I. Sales, and C. J. Ashworth. 1986. Maternal and embryonic factors associated with prenatal loss in mammals. J. Reprod. Fert. 76:851-864.

Wirth-Dzieciolowska, E. M. 1987. Survival of embryos in relation to the vasculature of implantation places in laboratory mice. Genetica Polonica 28:127-130.

Xie, S., D. M. Broermann, K. P. Nephew, R. D. Geisert, and W. F. Pope. 1990. Ovulation and early embryogenesis in swine. Biol. Reprod. 43:236-240.

Zimmerman, D. R., and P. J. Cunningham. 1975. Selection for ovulation rate in swine: population, procedures and ovulation response J. Anim. Sci. 40: 61-69. 



\section{Chapter 5}

Selection for ovulation rate in rabbits: direct and correlated responses estimated with a cryopreserved control population.

P. Laborda ${ }^{1}$, M. A. Santacreu ${ }^{1}$, A. Blasco ${ }^{1}$ and M. L. Mocé ${ }^{1,2}$

${ }^{1}$ Instituto de Ciencia y Tecnología Animal, Universidad Politécnica de Valencia, 46071 Valencia. Spain; ${ }^{2}$ Departamento de Producción Animal y Ciencia y Tecnología de los Alimentos. Universidad Cardenal Herrera-CEU. Edificio Seminario. 46113 Moncada, Valencia. Spain.

Submitted to Journal Animal Science, October, 2011 



\section{Abstract}

The aim of this work was to evaluate the response in 10 generations of selection for ovulation rate using a cryopreserved control population. Selection was based on the phenotypic value of ovulation rate estimated at day 12 of second gestation by laparoscopy. To produce the control line, embryos from 50 donor females and 18 males, belonging to the base generation of the line selected for ovulation rate, were recovered. A total of 467 embryos (72 hours embryos) were vitrified and stored in liquid $\mathrm{N}_{2}$ for 10 generations. The size of both lines was approximately 10 males and 50 females. The number of records used to analyse the different traits ranged from 99 to 340. Data were analysed using Bayesian methodology. A difference between the selected and the control line of 2.1 ova $\left(\operatorname{HPD}_{95 \%}[1.3,2.9]\right)$ was observed in ovulation rate (OR), but it was not accompanied by a correlated response in litter size (LS) (-0.3; HPD $\left._{95 \%}[-1.1,0.5]\right)$. The number of implanted embryos (IE) increased with selection in 1.0 embryo $\left(\mathrm{HPD}_{95 \%}[-0.6,2.0]\right)$, but this increase was not relevant. Prenatal survival (PS), embryonic survival (ES) and fetal survival (FS) were calculated as LS/OR, IE/OR and $\mathrm{LS} / \mathrm{IE}$, respectively. Prenatal survival was reduced with selection (-0.12; HPD $95 \%$ [-0.20, $0.04])$, basically due to a decrease in FS $\left(-0.12\right.$ HPD $\left._{95 \%}[-0.19,-0.06]\right)$. Embryonic survival (ES) showed a slight decrease $\left(-0.05 ; \mathrm{HPD}_{95 \%}[-0.12,0.02]\right)$. In summary, comparison with a control line showed that ovulation rate in rabbits increased with selection without any correlated response in litter size, basically due to a decrease in fetal survival.

\section{Introduction}

Selection for ovulation rate has been unsuccessful, as a means of improving indirectly litter size, in pigs and mice, despite the increase in ovulation rate (Cunningham et al., 1979; Rosendo et al., 2007; Leymaster and Christenson, 2000 in pigs; Land and Falconer, 1969; Bradford, 1969 in mice). The lack of correlated response in litter size has been associated with an increase in the post-implantation mortality (Freking et al., 2007 in pigs; Bradford et al., 1969 in mice). Response to selection for ovulation rate in rabbits was assessed in previous studies using predicted genetic trends (Laborda et al., $2011 a, b)$. Predicted genetic trends have the disadvantage of being dependent on the 
model and on the genetic parameters of the traits analysed (Sorensen and Johansson, 1992). The limited number of data in this type of experiments and the scarce number of experiments lead to estimation of genetic parameters with high standard errors, especially genetic correlations; therefore the correlated responses estimated with genetic trends have low accuracy. Response to selection estimated with genetic trends can be complemented using control populations. Control populations are less modeldependent, but they depend on the limited experimental facilities that should be shared by the selected and the control lines. Cryopreserved control populations are less common in selection experiments, although they present lower genetic drift and absence of unintended selection, allowing a better use of the facilities (Hill, 1972).

The aim of this study was to estimate direct response to selection for ovulation rate and correlated responses on litter size and its components by contrasting the selected line to a cryopreserved control population.

\section{Material and Methods}

\section{Animals}

All experimental procedures involving animals were approved by the Polytechnic University of Valencia Research Ethics Committee. Animals came from an experiment of selection for ovulation rate described by Laborda et al. (2011a) and from a cryopreserved control population, detailed below. The ovulation rate line was selected for 10 generations; then, selection was relaxed for one generation. Females from generation 11 of the selected line and females from the control line were used to assess direct and correlated responses. Animals of both lines were housed at the experimental farm of the Universidad Politécnica de Valencia in individual cages. They were kept under controlled 16-h light: 8-h dark photoperiods and fed a commercial diet. Matings were planned to avoid inbreeding. Laparoscopies were performed on all does at $\mathrm{d} 12$ of their second gestation. Details of the technique are given by Santacreu et al. (1990). 


\section{Embryo transfer and control line}

To produce the control line, embryos from 50 donor females and 18 males, belonging to the base generation of the line selected for ovulation rate, were recovered. Details of the process of embryo recovery are available in Mocé et al. (2009). A total of 467 embryos (72 hours embryos) were vitrified and stored in liquid $\mathrm{N}_{2}$ until transfer. Embryos were vitrified and thawed according to the method described by Vicente et al. (1999). Recipient females $(n=40)$ were nulliparous females of 19 to $20 w k$ of age, synchronized by intramuscular administration of $1 \mathrm{mg}$ buserelin acetate (Hoechst, Marion Roussel, Madrid, Spain) twenty-one days before the transfer. Only females that presented vulva colour associated with receptive status were induced to ovulate with a second administration of buserelin acetate. The second administration was administered 60 to $63 \mathrm{~h}$ before transfer (Vicente et al., 1999). To perform the transfers, rabbits were anesthetized with an im administration of xylazine (Rompun 2\%; Bayer AG, Leverkusen, Germany) at a rate of $4 \mathrm{mg} / \mathrm{kg}$ body weight; 5 min later an iv dose of ketamine $\mathrm{HCL}$ and clorbutol (Imalgène 500; Merial S.A., Lyon, France), at a rate of $15-30 \mathrm{mg} / \mathrm{kg}$ body weight was administered in the marginal ear vein. Embryo transfers were performed by using the laparoscopic technique described by Besenfelder and Brem (1993).

After parturitions, 1-2 daughters from each recipient female were randomly selected. Males were selected within each male family, i.e. one son of each male was selected. The control line consisted of 45 does and 10 males. This control line was contemporary to the $10^{\text {th }}$ generation of the line selected for ovulation rate. In order to eliminate the possible effects of cryopreservation, the control does were mated to produce the next generation; 1-2 daughters from each female were randomly selected and a total of 54 control females contemporary to generation 11 of the selected line were obtained. Males were selected within each male family. Animals from the control line contemporary to generation 11 of the selected line were used to assess direct and correlated responses. 
Traits

Litter size (LS) was estimated as the number of total born per litter; the number of kits born alive per litter (NBA) and the number of kits weaned per litter (NW), together with LS, were measured in a maximum of 4 parities in each females. Ovulation rate (OR), estimated as the number of corpora lutea in both ovaries and the number of implanted embryos (IE), estimated as the number of implantation sites were measured by laparoscopy at $\mathrm{d} 12$ of second gestation. Both the right and the left ovulation rates (ROR and LOR) and implanted embryos (RIE and LIE) were measured. Ovulatory difference (OD) was defined as the difference between the ROR and LOR, expressed as an absolute value; implantatory difference (ID), was defined as the difference between RIE and LIE, expressed as an absolute value. Embryonic survival (ES) was calculated as IE/OR, fetal survival (FS) was calculated as LS/IE and prenatal survival (PS) was calculated as LS/OR. Females had a second post mortem measurement of OR, ROR, LOR and OD. The weight of the female was measured at $d 12$ of second gestation, at laparoscopy time (WOR). The number of females and number of records used to analyze the traits $L S, N B A, N W, O R, R O R, L O R, O D, I E, R I E, L I E, I D, E S, F S, P S$ and WOR in the selected and the control line are shown in Table 1.

Table 1. Number of records used to analyze the traits ovulation rate (OR), right and left ovulation rate (ROR and $L O R)$, ovulatory difference $(O D=|R O R-L O R|)$, litter size (LS), number of kits born alive (NBA), number of kits weaned (NW), number of implanted embryos (IE), right and left implanted embryos (RIE and LIE), implantatory difference (ID=|RIE-LIE $\mid$ ), embryonic survival (ES), fetal survival (FS), prenatal survival (PS) and weight at second gestation (WOR) in the selected and the control line.

\begin{tabular}{|c|c|c|c|c|c|c|c|c|c|c|}
\hline Trait & OR & $\begin{array}{l}\text { OD, } \\
\text { ROR, } \\
\text { LOR }\end{array}$ & $\begin{array}{c}\text { LS, } \\
\text { NBA }\end{array}$ & NW & IE & $\begin{array}{l}\text { ID, } \\
\text { RIE, } \\
\text { LIE }\end{array}$ & ES & FS & PS & WOR \\
\hline Control $(n=54)$ & 91 & 88 & 162 & 162 & 48 & 46 & 48 & 47 & 48 & 48 \\
\hline Selected $(n=56)$ & 92 & 92 & 178 & 177 & 53 & 53 & 53 & 52 & 52 & 53 \\
\hline
\end{tabular}

$\mathrm{n}$ : number of females 


\section{Statistical Analysis}

Bayesian inference was used. The model assumed for OR, ROR, LOR, OD, LS, NBA and NW was:

$$
Y_{i j k l m n}=L_{i n e}+L_{j}+P_{k}+Y S_{I}+p_{i m}+e_{i j k l m n}
$$

where Line $_{i}$ is the effect of the line (2 levels: control and selected), $L_{j}$ is the effect of lactation state of the doe (2 levels: lactating and not lactating does when mated), $P_{k}$ is the effect of parity (4 levels for LS, NBA and NW; 2 levels for OR and OD), YS, is the effect of year-season ( 3 levels), $p_{i m}$ is the permanent environmental effect of doe and $e_{i j k l m n}$ is the residual of the model. The model for IE, RIE, LIE, ID, ES, FS, PS and WOR did neither have the parity effect nor the permanent environmental effect of doe, because records came only from the second parity, and the year-season effect had only 2 levels. Bounded uniform priors were used for all unknowns with the exception of the permanent effect, which was considered normally distributed with mean $\mathbf{0}$ and variance $I \sigma_{p}^{2}$, where $\mathbf{I}$ is a unity matrix, and $\sigma_{p}^{2}$ is the permanent effect variance of the trait. Residuals were normally distributed with mean $\mathbf{0}$ and variance $\mathbf{I} \sigma_{\mathrm{e}}^{2}$. The priors for the variances also were bounded uniform positive.

Features of the marginal posterior distribution of differences between line means were estimated by using the Gibbs sampling algorithm. Chains of 1,000,000 samples each were used, with a burning period of 200,000 . One sample each 50 was saved to avoid high correlations between consecutive samples. Convergence was tested using the $Z$ criterion of Geweke.

\section{Results and discussion}

Table 2 shows raw means and standard deviations for the traits measured in the control line; the values of the traits OR, LS, NBA, NW, IE and survival rates are in agreement with values published by other authors in maternal rabbit lines (Brun et al., 1992; García et al., 2001; García and Baselga, 2002; Piles et al., 2006; Theau-Clement et al., 2009; Ragab and Baselga, 2011). The value of WOR agrees with other estimates of pregnant female weights in commercial rabbit lines (for example see Feugier and Fortun-Lamothe, 2006; Martínez-Vallespín et al., 2011). No values for the traits OD and ID have been found in the literature. 
Table 2. Control line: means, SD, standard errors (SE), coefficients of variation (CV) and units of ovulation rate (OR), right and left ovulation rate (ROR and LOR), litter size (LS), number of kits born alive (NBA), number of kits weaned (NW), number of implanted embryos (IE), right and left implanted embryos (RIE and LIE), ovulatory difference (OD=|ROR-LOR $\mid$ ), implantatory difference (ID=|RIE-LIE $\mid$ ), embryonic survival (ES), fetal survival (FS), prenatal survival (PS) and adult weight at second gestation (WOR).

\begin{tabular}{lccccc}
\hline \hline Trait & mean & SD & SE & CV & unit \\
\hline OR & 14.4 & 2.2 & 0.2 & 15.3 & ovum \\
ROR & 7.6 & 2.4 & 0.3 & 32.9 & ovum \\
LOR & 6.7 & 2.3 & 0.2 & 33.1 & ovum \\
OD & 3.5 & 2.6 & 0.3 & 74.0 & ovum \\
& & & & & \\
LS & 9.2 & 2.9 & 0.2 & 31.2 & kit \\
NBA & 8.3 & 3.3 & 0.3 & 40.1 & kit \\
NW & 6.8 & 3.3 & 0.3 & 47.6 & kit \\
& & & & & embryo \\
IE & 11.8 & 3.1 & 0.5 & 26.4 & embryo \\
RIE & 6.0 & 2.3 & 0.4 & 42.7 & embryo \\
LIE & 5.9 & 2.5 & 0.4 & 44.9 & embryo \\
ID & 3.4 & 2.6 & 0.4 & 77.4 & g \\
FS & & & & & \\
FS & 0.84 & 0.18 & 0.03 & 21.0 & embryos/ova \\
PS & 0.85 & 0.15 & 0.02 & 17.1 & kits/embryos \\
& 0.70 & 0.17 & 0.02 & 24.8 & kits/ova \\
\hline
\end{tabular}

Features of the marginal posterior distributions of the differences between the selected and the control line for the traits measured are presented in Tables 3, 4, 5 and 6. We considered a relevant response to selection (value R) when the difference between lines (value D) was at least $10 \%$ of the mean of the control line, i.e. an increase of $1 \%$ per generation (10 generations). Using Bayesian inference, we can calculate the probability of the difference between lines being higher or lower than 
zero $\left(P_{0}\right)$, the probability of having a relevant response to selection $\left(P_{R}\right)$, which is the probability of the difference being higher than the value $R$ when $D$ is positive or lower than $R$ when $D$ is negative, and the probability of not having a relevant response to selection $\left(P_{N R}=1-P_{R}\right)$, which is the probability of the difference lying in the interval $[-R,+R]$.

\section{Ovulation rate}

As it is shown in Table 2, OR was 14.4 in the control line. A difference between the selected and the control line of at least 1.4 ova (value R, Table 3) was expected in order to assess that response to selection had been successful. There was a difference of 2.1 ova between the selected and the control line (value D, Table 3), which represents an increase of $1.5 \%$ per generation. The probability of this difference being higher than $\mathrm{R}$ was 0.95 (Table 3). This was a relevant response, at least 1.4 ova ( $k=1.4$, Table 3). The response estimated with genetic trends (1.3 ova) in Laborda et al. (2011a). A small response to selection was observed in ROR ( $D=0.8$ ova, $P_{0}=0.98$; Table 3). In LOR, the difference between lines was 1.4 ova ( $k=0.8$ ova, Table 3), showing a relevant response in the left ovary $\left(P_{R}=0.98\right.$, Table 3$)$. The response in ROR is similar to the response estimated by Laborda et al. (2011a) (1.1 ova), but the response in LOR is in disagreement with the genetic trend. The genetic trend estimated by Laborda et al. (2011a) showed a correlated response to selection of 0.5 ova in the left ovary, but the genetic correlation between OR and LOR was estimated with low accuracy HPD $_{95 \%}$ $[0.23,1.00])$. Then, no conclusions regarding the response in LOR can be drawn.

Adult weight at second gestation increased $267 \mathrm{~g}$ with selection (Table 3). However, this difference was not relevant $\left(P_{N R}=0.96\right.$, Table 3$)$. Moreover, when the variable WOR was used as a covariate to analyse OR, the difference between lines in OR practically did not change (from 2.1 to 1.8). Quirino et al. (2009) reported a genetic correlation between OR and WOR of 0.49 in the same rabbit line, however no other study has been found dealing with genetic correlations between ovulation rate and body weight of the adult rabbit female. In mice, ovulation rate has been found to be positively correlated with weight of the female at mating, especially in experiments where litter size had been standardized (reviewed by Bünger et al., 2005). In pigs, results are wide 
ranging (from -0.30 to 0.30 approximately) and in general they were estimated with high standard errors (Young et al., 1978; Bidanel et al., 1996; Rosendo et al., 2007).

Table 3. Features of the estimated marginal posterior distributions of the differences between the selected and the control line for ovulation rate (OR), right and left ovulation rate (ROR and $L O R)$, ovulatory difference $(O D=|R O R-L O R|)$ and weight at second gestation (WOR).

\begin{tabular}{lccccccc}
\hline \hline Trait & $\mathbf{D}$ & HPD $_{95 \%}$ & $\mathbf{R}$ & $\mathbf{P}_{0}$ & $\mathbf{P}_{\mathrm{R}}$ & $\mathbf{P}_{\mathrm{NR}}$ & $\mathbf{k}$ \\
\hline OR (ova) & 2.1 & $1.3,2.9$ & 1.4 & $1.00^{\mathrm{a}}$ & $0.95^{\mathrm{a}}$ & 0.05 & $1.4^{\mathrm{a}}$ \\
ROR (ova) & 0.8 & $-0.1,1.4$ & 0.8 & $0.98^{\mathrm{a}}$ & $0.49^{\mathrm{a}}$ & 0.51 & $0.1^{\mathrm{a}}$ \\
LOR (ova) & 1.4 & $0.6,2.0$ & 0.7 & $1.00^{\mathrm{a}}$ & $0.98^{\mathrm{a}}$ & 0.02 & $0.8^{\mathrm{a}}$ \\
OD (ova) & -0.6 & $-1.4,0.1$ & -0.3 & $0.94^{\mathrm{b}}$ & $0.76^{\mathrm{b}}$ & 0.23 & $0.0^{\mathrm{b}}$ \\
WOR (g) & 267 & 101,441 & 420 & $1.00^{\mathrm{a}}$ & $0.04^{\mathrm{a}}$ & 0.96 & $115^{\mathrm{a}}$ \\
\hline
\end{tabular}

D: posterior mean of the difference between the selected and the control line. $\mathrm{HPD}_{95 \%}$ : highest posterior density interval of the difference at $95 \%$. R: $10 \%$ of the mean of the control line ( $1 \%$ per generation, 10 generations). $P_{0}$ : probability of $D$ being ${ }^{a}$ higher than zero ${ }^{b}$ lower than zero. $P_{R}$ : probability of response (probability of $D$ being ${ }^{a}$ higher than $R,{ }^{b}$ lower than $R$ ). $P_{N R}$ : probability of noresponse (probability of $D$ lying in the interval $[-R,+R])$. $k$ : limit for the interval ${ }^{a}[k,+\infty),{ }^{b}(-\infty, k]$, having a probability of $95 \%$.

\section{The number of implanted embryos}

The IE increased with selection (1.0 embryo, Table 4), but the probability of this difference being higher than $\mathrm{R}$ was low $(0.36$, Table 4$)$, showing no relevant correlated response in IE. Little can be said about the correlated responses in RIE and LIE (see $P_{R}$ and $\mathrm{P}_{\mathrm{NR}}$, Table 4) due to their large $\mathrm{HPD}_{95 \%}$ interval. It seems that the correlated response in RIE agrees with the genetic trend (0.8 embryos; Laborda et al., 2011b). The correlated response in LIE should be taken with caution as it happens with the response in LOR.

Laborda et al., $(2011 a, b)$ suggested that an increase in OD could have been related to the lacking correlated response in LS in the line selected for ovulation rate. This and the absence of embryo uterine transmigration could have caused an associated increase in ID, disfavouring FS and therefore PS in the overcrowded uterine horn. The 
estimated genetic correlation of OR with ID was positive, however no correlated response was observed on ID after 10 generations (Laborda et al., 2011b). Moreover, the genetic correlation of ID with PS and LS were estimated with low accuracy and nothing could be concluded. Contrary to what was expected, in this experiment, OD and ID were lower in the selected line than in the control line $\left(P_{0}=0.94\right.$ and $P_{0}=0.97$, Tables 3 and 4, respectively). The differences between lines in OD and ID had a probability of obtaining a relevant response against the selected line of 0.76 and 0.89 , respectively. These results should be taken with caution, due to the large $\mathrm{HPD}_{95 \%}$ intervals and because OD and ID are highly variable traits (Table 2).

Table 4. Features of the estimated marginal posterior distributions of the differences between the selected and the control line for the number of implanted embryos (IE), right and left implanted embryos (RIE and LIE) and implantatory difference (ID=|RIE-LIE $\mid)$.

\begin{tabular}{lcccccc}
\hline \hline Trait & $\mathbf{D}$ & HPD $_{95 \%}$ & $\mathbf{R}$ & $\mathbf{P}_{\mathbf{0}}$ & $\mathbf{P}_{\mathbf{R}}$ & $\mathbf{P}_{\mathrm{NR}}$ \\
\hline IE (embryo) & 1.0 & $-0.6,2.0$ & 1.2 & $0.92^{\mathrm{a}}$ & $0.36^{\mathrm{a}}$ & 0.64 \\
RIE (embryo) & 0.5 & $-0.4,1.5$ & 0.6 & $0.86^{\mathrm{a}}$ & $0.42^{\mathrm{a}}$ & 0.57 \\
LIE (embryo) & 0.4 & $-0.6,1.5$ & 0.6 & $0.80^{\mathrm{a}}$ & $0.37^{\mathrm{a}}$ & 0.60 \\
ID (embryo) & -0.8 & $-1.8,0.0$ & -0.3 & $0.97^{\mathrm{b}}$ & $0.89^{\mathrm{b}}$ & 0.11 \\
\hline
\end{tabular}

D: posterior mean of the difference between the selected and the control line. $\mathrm{HPD}_{95 \%}$ : highest posterior density interval of the difference at 95\%. R: $10 \%$ of the mean of the control line (1\% per generation, 10 generations). $P_{0}$ : probability of $D$ being ${ }^{a}$ higher than zero ${ }^{b}$ lower than zero. $P_{R}$ : probability of response (probability of $D$ being ${ }^{a}$ higher than $R,{ }^{b}$ lower than $R$ ). $P_{N R}$ : probability of no-response (probability of $D$ lying in the interval $[-R,+R])$.

\section{Survival rates}

Prenatal survival was lower in the selected line than in the control line ( $D=-0.12$ ova, $P_{0}=1.00$, Table 5). It had a probability of $87 \%$ of being lower than -0.07 (value $R$, Table $5)$, indicating a relevant correlated response in PS against the selected line. Most of the response in PS was due to a decrease in FS. There was a difference of -0.12 between lines (value D, Table 5), having a probability of 0.86 of being relevant. Embryonic survival had a probability of $91 \%$ of being lower in the selected line than in the control 
line $(D=-0.05$; Table 5) and was responsible for the low correlated response observed in IE. However, this correlated response was not relevant $\left(P_{\mathrm{NR}}=0.83\right.$, Table 5). Laborda et al. (2011b) observed no correlated response estimated with genetic trends in ES, because the genetic correlation between OR and ES was close to zero; however, this correlation was estimated with low accuracy. Responses in FS and PS estimated with the cryopreserved control population were similar to the responses estimated with genetic trends. The possible causes for the decrease in prenatal survival were discussed by Laborda et al. (2011a,b).

Table 5. Features of the estimated marginal posterior distributions of the differences between the selected and the control line for embryonic survival (ES), fetal survival (FS) and prenatal survival (PS).

\begin{tabular}{lccccccc}
\hline Trait & $\mathbf{D}$ & $\mathbf{H P D}_{95 \%}$ & $\mathbf{R}$ & $\mathbf{P}_{\mathbf{0}}$ & $\mathbf{P}_{\mathbf{R}}$ & $\mathbf{P}_{\mathrm{NR}}$ & $\mathbf{k}$ \\
\hline ES & -0.05 & $-0.12,0.02$ & -0.08 & 0.91 & 0.17 & 0.83 & 0.01 \\
FS & -0.12 & $-0.19,-0.06$ & -0.08 & 1.00 & 0.86 & 0.14 & -0.06 \\
PS & -0.12 & $-0.20,-0.04$ & -0.07 & 1.00 & 0.87 & 0.13 & -0.05 \\
\hline
\end{tabular}

D: posterior mean of the difference between the selected and the control line. $\mathrm{HPD}_{95 \%}$ : highest posterior density interval of the difference at $95 \%$. R: $10 \%$ of the mean of the control line (1\% per generation, 10 generations). $P_{0}$ : probability of $D$ being lower than zero. $P_{R}$ : probability of response (probability of $D$ being lower than $R$ ). $P_{N R}$ : probability of no-response (probability of $D$ lying in the interval $[-R,+R]$ ). $k$ : limit for the interval $(-\infty, \mathrm{k}]$, having a probability of $95 \%$.

\section{Litter size}

In rabbits, direct response to selection for litter size has been usually close to $1 \%$ per generation (see review in Mocé and Santacreu, 2010). Selection for ovulation rate should have a higher response than direct selection for litter size to be considered as an alternative. Litter size, NBA and NW presented no relevant differences between the selected and the control line; the difference between lines had a high probability of lying in the intervals $[-R,+R](0.94,0.86$ and 0.88 , respectively; Table 6). These results corroborate the results obtained by Laborda et al. (2011a) with genetic trends, where no correlated response to selection was observed in LS. 
Table 6. Features of the estimated marginal posterior distributions of the differences between the selected and the control line for litter size (LS), number of kits born alive (NBA) and number of kits weaned (NW).

\begin{tabular}{lcccccc}
\hline \hline Trait & $\mathbf{D}$ & HPD $_{95 \%}$ & $\mathbf{R}$ & $\mathbf{P}_{\mathbf{0}}$ & $\mathbf{P}_{\mathrm{R}}$ & $\mathbf{P}_{\mathrm{NR}}$ \\
\hline LS (kit) & -0.3 & $-1.1,0.5$ & -0.9 & 0.74 & 0.06 & 0.94 \\
NBA (kit) & -0.3 & $-1.2,0.6$ & -0.8 & 0.74 & 0.13 & 0.86 \\
NW (kit) & -0.2 & $-0.9,0.6$ & -0.7 & 0.68 & 0.10 & 0.88 \\
\hline
\end{tabular}

D: posterior mean of the difference between the selected and the control line. $\mathrm{HPD}_{95 \%}$ : highest posterior density interval of the difference at $95 \%$. R: $10 \%$ of the mean of the control line (1\% per generation, 10 generations). $P_{0}$ : probability of $D$ being lower than zero. $P_{R}$ : probability of response (probability of $D$ being lower than $R$ ). $P_{N R}$ : probability of no-response (probability of $D$ lying in the interval $[-R,+R]$ ).

In rabbits selected for ovulation rate, the genetic correlation between ovulation rate and litter size was estimated with low accuracy, as in the experiments of selection for ovulation rate in other polytocous species (Cunningham et al., 1979; Rosendo et al., 2007 in pigs; Bradford, 1969; Land and Falconer, 1969 in mice). Therefore, conclusions about its value should be taken with caution. However, the correlated response in litter size estimated with the control line support that the correlation between ovulation rate and litter size should be close to zero; the use of a control population strengthens the results obtained with genetic trends for most of the traits, giving evidence of the adequacy of the model and the genetic parameters estimated.

In conclusion, comparison with a control line shows that 10 generations of selection for ovulation rate in rabbits has increased ovulation rate by about 2 ova, but it has not been accompanied by a correlated response in litter size, mainly due to a decrease in fetal survival.

\section{Literature cited}

Besenfelder U., and G. Brem. 1993. Laparoscopic embryo transfer in rabbits. J. Reprod. Fertil. 99:53-56. 
Bidanel, J. P., J. Gruand, and C. Legault. 1996. Genetic variability of age and weight at puberty, ovulation rate and embryo survival in gilts and relations with production traits. Genet. Sel. Evol. 28:103-117.

Bradford, G. E. 1969. Genetic control of ovulation rate and embryo survival in mice. I. Response to selection. Genetics 61:907-918.

Brun, J. M., G. Bolet, and J. Ouhayoun. 1992. The effects of crossbreeding and selection on productive and reproductive traits in a triallel experiment between three strains of rabbits. J. Appl. Rabbit Res. 15:181-189.

Bünger, L., M. R. Lewis, M. F. Rothschild, A. Blasco, U. Renne, and G. Simm. 2005. Relationships between quantitative and reproductive fitness traits in animals. Phil. Trans. R. Soc. B 360:1489-1502.

Cunningham, P. J., M. E. England, L. D. Young, and D. R. Zimmerman. 1979. Selection for ovulation rate in swine: Correlated response in litter size and weight. J. Anim. Sci. 48:509-516.

Feugier, A., and L. Fortun-Lamothe. 2006. Extensive reproductive rhythm and early weaning improve body condition and fertility of rabbit does. Anim. Res. 55:459470.

Freking, B. A., K. A. Leymaster, J. L. Vallet, and R. K. Christenson. 2007. Number of fetuses and conceptus growth throughout gestation in lines of pigs selected for ovulation rate or uterine capacity. J. Anim. Sci. 85:2093-2103.

García, M. L., Baselga, M., Lavara, R., and Vicente, J. S. 2001. Respuesta a la selección por tamaño de camada en conejo. I. Componentes del tamaño de camada. IX Jornadas sobre producción animal, Zaragoza, Spain 22 (I):78-80.

García, M. L., and M. Baselga. 2002. Estimation of genetic response to selection in litter size of rabbits using a cryopreserved control population. Livest. Prod. Sci. 74:4553. 
Hill, W. G. 1972. Estimation of genetic change. General theory and design of control populations. Anim. Breed. Abst. 40:1-15.

Laborda, P., M. L. Mocé, M. A. Santacreu, and A. Blasco. 2011a. Selection for ovulation rate in rabbits: genetic parameters, direct response and correlated response on litter size. J. Anim. Sci. 89:2981-2987.

Laborda, P., M. L. Mocé, A. Blasco, and M. A. Santacreu. 2011b. Selection for ovulation rate in rabbits: genetic parameters and correlated responses on survival rates. J. Anim. Sci., published online September 16, 2011.

Land, R. B., and D. S. Falconer. 1969. Genetic studies of ovulation rate in the mouse. Genet. Res. 13:25-46.

Leymaster, K. A., and R. K. Christenson. 2000. Direct and correlated responses to selection for ovulation rate or uterine capacity in swine. J. Anim. Sci. 78(Suppl. 1):68. (Abstr.).

Martínez-Vallespín B., E. Martínez-Paredes, L. Ródenas, C. Cervera, J. J. Pascual, and E. Blas. Combined feeding of rabbit female and young: Partial replacement of starch with acid detergent fibre or/and neutral detergent soluble. Livestock Science (2011), doi:10.1016/j.livsci.2011.05.014.

Mocé, M. L., A. Blasco, and M. A. Santacreu. 2009. In vivo development of vitrified rabbit embryos: effects on prenatal survival and placental development. Theriogenology 73:704-710.

Mocé, M. L., and M. A. Santacreu. 2010. Genetic improvement of litter size in rabbits: a review. CD-Proc. 9th World Congr. Genet. Appl. Livest. Prod. Leipzig, Germany.

Quirino C., R. Peiró, M. A. Santacreu, and A. Blasco, 2009. Genetic correlation between liveweight and ovulation rate in rabbits. $60^{\text {th }}$ EAAP, Barcelona, Spain.

Piles, M., M. L. García, O. Rafel, J. Ramon, and M. Baselga. 2006. Genetics of litter size in three maternal lines of rabbits: Repeatability versus multiple-trait models. J. Anim. Sci. 84:2309-2315. 
Ragab, M., and M. Baselga. 2011. A comparison of reproductive traits of four maternal lines of rabbits selected for litter size at weaning and founded on different criteria. Livestock Science 136:201-206.

Rosendo, A., T. Druet, J. Gogué, and J. P. Bidanel. 2007. Direct responses to six generations of selection for ovulation rate or prenatal survival in Large White pigs. J. Anim. Sci. 85:356-364.

Santacreu, M. A., M. P. Viudes, and A. Blasco. 1990. Evaluation par coelioscopie des corps jaunes et des embryons. Influence sur la taille de portee chez la lapine. Reprod. Nutr. Dev. 30:583-588.

Sorensen, D., and K. Johansson. 1992. Estimation of direct and correlated responses to selection using univariate animal models. J. Anim. Sci. 70: 2038-2044.

Theau-Clement, M., P. Salvetti, G. Bolet, G. Saleil, and T. Joly. 2009. Influence de l'intervalle entre le sevrage et l'insemination sur la production d'embryons et leur qualité chez la lapine. 13émes Journées de la Recherche Cunicole. INRAITAVI, Le Mans, France. Pages 125-128.

Vicente J. S., M. P. Viudes-de-Castro, and M. L. García. 1999. In vivo survival rate of rabbit morulae after vitrification in a medium without serum protein. Reprod. Nutr. Dev. 39:657-662.

Young L. D., R. A. Pumfrey, P. J. Cunningham, and D. R. Zimmerman. 1978. Heritabilities and genetic and phenotypic correlations for prebreeding traits, reproductive traits and principal components. J. Anim. Sci. 46:937-949. 


\title{
Chapter 6
}

\section{General discussion}

\author{
P. Laborda
}

Instituto de Ciencia y Tecnología Animal, Universidad Politécnica de Valencia, 46071 Valencia. Spain. 



\section{Experiments of selection for litter size and its components}

\subsection{Selection for ovulation rate and correlated response in litter size}

Selection for ovulation rate was proposed in mice as an indirect way of increasing litter size (Bradford, 1969; Land and Falconer, 1969). Based on the assumption that ovulation rate and litter size were correlated (Falconer, 1963), they suggested that, if the heritability of ovulation rate was higher than that of litter size, selection for ovulation rate would be more efficient than direct selection for litter size. Other experiments of selection for ovulation rate were proposed in pigs with similar expectations (Cunningham et al., 1979; Leymaster and Christenson, 2000; Rosendo et al., 2007). However, selection for ovulation rate in these five experiments did not improve litter size. In spite of this, an experiment of selection for ovulation rate was performed in rabbits expecting different results than in the other species. In rabbits there is no uterine transmigration, unlike in pigs, and increasing ovulation rate in both ovaries could lead to a higher number of fetuses in the less overcrowded uterine horn, probably leading to an increase in litter size. In mice, there is no uterine transmigration either; however, selection for ovulation rate was not successful improving litter size. There are only two experiments of selection for ovulation rate in mice, and generalizations from these experiments to other species should be made carefully. Besides, the results obtained in the experiments of selection for ovulation rate in mice are somewhat confusing: response to selection estimated with the control lines were presented without standard errors in both studies, and the correlated response in litter size in one of the experiments did not follow any clear pattern (Land and Falconer, 1969).

In our experiment, the response in ovulation rate estimated with genetic trends was 1.3 ova in 10 generations (chapter 3), and it was 2.1 ova $\left(\operatorname{HPD}_{95 \%}[1.3,2.9]\right)$ when comparing the selected and the control lines (chapter 5). Direct response to selection represented an increase of approximately 1 to $1.4 \%$ per generation. In mice and pigs selected for high ovulation rate, the increase of direct response per generation ranged from 1.2 to $2.6 \%$ in mice and from 2.6 to $3.6 \%$ in pigs. In all experiments of selection for ovulation rate, the correlated response in litter size was close to zero showing a decrease in prenatal survival. 
The nature of this kind of experiments, which need laparoscopies, laparotomies or slaughtering the female to measure ovulation rate, prevents from collecting a large number of data, making the estimation of accurate genetic correlations difficult. The estimated genetic correlations between ovulation rate and litter size were 0.07 (Cunningham et al., 1979), 0.41 (Rosendo et al., 2007) and -0.20 (Chapter 3 of this Thesis), but they were estimated with low accuracy. Other estimated genetic correlations found in the literature range from -0.8 to 0.8 (reviewed by Blasco et al., 1993a), having also high standard errors. Therefore, it is not possible to draw conclusions about their value. However, the lack of correlated response in litter size estimated with control populations in pigs (Cunningham et al., 1979; Leymaster and Christenson, 2000; Rosendo et al., 2007), mice (Bradford, 1969; Land and Falconer, 1969) and chapter 5 of this Thesis corroborated that the correlation found between ovulation rate and litter size should be close to zero.

\subsection{Selection for litter size and its correlated response in ovulation rate}

Selection to improve litter size in pigs, rabbits and mice lead to correlated responses in ovulation rate without or with small changes in prenatal survival (Bolet et al., 1989; Haley and Lee, 1992 in pigs; Brun et al., 1992; García and Baselga, 2002 in rabbits; Falconer 1963; Bakker et al., 1978; Gion et al., 1990 in mice). However, in the experiments of selection for high ovulation rate in pigs, rabbits and mice a decreased prenatal survival was observed, with no modification in litter size, as explained before. The different responses to selection for litter size and for ovulation rate might be explained through the gene frequencies of the traits and their pleiotropic effects. It is reasonable to suppose that the genes affecting prenatal loss should be at low frequencies, because they are unfavourable genes under natural selection (Falconer, 1963). On the other hand, the genes that increase ovulation rate should be at intermediate frequencies, because it should be favoured by natural selection, but still able to increase through artificial selection (Falconer, 1963). Under this supposition, selection to improve litter size, a natural index of ovulation rate and prenatal survival, would decrease little the already low frequencies of the genes that cause prenatal loss, while it would increase the frequencies of the genes that improve ovulation rate, 
overcoming the effects of the pleiotropic genes. On the other hand, when selection is performed for ovulation rate, the pleiotropic genes that affect ovulation rate and prenatal loss would cause an increment in prenatal loss parallel to the increase in ovulation rate, avoiding the expected correlated response in litter size.

\section{Physiological causes for the lacking correlated response in litter size}

The lack of correlated response in litter size to selection for ovulation rate may have several explanations from a physiological point of view. Prenatal mortality can either happen in the embryonic or in the fetal period. In our experiment, a small correlated response in embryonic survival, expressed as a percentage, of $-5 \%$ in 10 generations (around $0.6 \%$ of the mean per generation) was observed when the selected line was compared with the control line (chapter 5 of this Thesis), while no change was observed with the genetic trend. Fetal survival, expressed as a percentage, decreased approximately $10 \%$ in 10 generations (chapters 4 and 5 of this Thesis). This implies a decrease of 1 to $1.5 \%$ of the mean per generation. There is no much information of the timing of prenatal mortality in pigs and mice selected for ovulation rate. In agreement with our results, Bradford (1969) in mice and Freking et al. (2007) in pigs observed that most prenatal mortality occurred during the fetal period.

The factors that could increase embryonic or fetal mortality in females with high ovulation rate are: a higher proportion of immature oocytes, a greater variability in embryonic development and a higher embryonic or fetal competence for resources (reviewed by Santacreu, 2006 in rabbits; Geisert and Schmitt, 2002 in pigs).

\subsection{Oocyte maturation}

Similar to superovulated females, which release oocytes that are less competent (reviewed by Krisher, 2004), females with extremely high ovulation rates could ovulate oocytes in an early stage of development, which may not be fertilized or may lead to poor-quality embryos that may die either before or after implantation. For example, in one of the experiments of selection for high ovulation rate in pigs, Koenig et al. (1986) found a higher proportion of oocytes classified as immature based on a chromosomal analysis in the selected females compared to unselected females, and in superovulated 
females compared to naturally ovulated ones; they suggested that immaturity of ova may account for a substantial proportion of prenatal mortality in gilts with high ovulation rate. In our experiment, the proportion of females with extremely high OR (more than 20 ova; i.e., twice the standard deviation over the mean) increased with selection from $4 \%$ to $23 \%$.

There are many methods to assess oocyte quality. Several authors have proposed the measurement of glutathione (GSH) and ATP inside the cell (reviewed by Krisher, 2004). ATP and GSH are stored during the follicular maturation of the oocyte, and are necessary for its development. Therefore, less developed oocytes have lower levels of ATP and GSH than more developed ones, and have a higher probability to die. In the experiment of selection for ovulation rate in rabbits, no differences in ATP or GSH were found between the oocytes in the selected and the control lines (data not shown).

\subsection{Variability in embryonic development}

An increased variability in embryonic development may appear in females with extremely high ovulation rates due to an extended ovulation. Oocytes which ovulate first are fertilized earlier and advance the uterine secretions (Torres et al., 1984 in rabbits; Pope, 1988 and Xie at al., 1990 in pigs; Wilmut et al., 1986 and Al-Shorepy et al., 1992 in mice). Asynchrony between embryonic development and uterine secretions can cause retarded embryonic development, as shown in asynchronous embryo transfer experiments in rabbits (Wintenberger-Torres, 1974; Torres et al., 1987). It has been suggested that lesser developed embryos are able to implant, and it is in the postimplantation period when they probably die (Wintenberger-Torres et al., 1974 in rabbits; Pope et al., 1988; Wilde et al., 1988 in pigs). In our selection experiment, preliminary results of an analysis of embryonic variability at $72 \mathrm{~h}$ p.c. seem to indicate a retarded stage of embryonic development in females from the selected line compared to the control line (data not shown). This could imply a greater embryonic uterine asynchrony in the selected line, probably contributing to the prenatal mortality. 


\subsection{Uterine overcrowding}

In rabbit females with extremely high ovulation rate, uterine overcrowding could reduce litter size. Moreover, in females which present high ovulatory difference, the absence of embryonic transuterine migration could cause the overcrowding of one uterine horn, reducing litter size on that side, while the other uterine horn remained less occupied. The phenomenon of the uneven embryo distribution through both uterine horns was called implantatory difference in the chapter 4 of this Thesis; a possible increase of this trait with selection for ovulation rate was proposed as a cause for the lacking correlated response in litter size. In the experiment of selection for ovulation rate, prenatal survival was around $10 \%$ lower in females with high ID than in females without ID (data not shown). However, the correlated response to selection in ID did not have a clear pattern: genetic trends showed a small increase of ID with selection, but this increase was not confirmed with the control line. It seems that implantatory difference is a highly variable trait, and in this experiment it has not been possible to determine if an increase in this trait was responsible for the increased fetal mortality with selection.

In females with extremely high ovulation rate and overcrowded uterine horns, the reduced blood supply to the fetus might be an important factor decreasing litter size. The vascular supply to the fetus is especially important in rabbits due to their hemochorial placenta, an invasive placenta where fetal tissues directly contact the maternal blood supply (reviewed by Leiser and Kaufmann, 1994). Rabbit fetuses and fetal placentas are more developed when they receive more than four blood vessels (Argente et al. 2003; Mocé et al., 2004). Fetuses with poor blood supply have a higher probability to die. In rabbits, Argente et al. (2003) observed that each additional implanted embryo implied a decrease in the blood flow that reached each fetus, reducing fetal and placental weight and increasing their probability to die.

In conclusion, selection for high ovulation rate in rabbits has been effective, but no correlated response has been observed in litter size. Females selected for ovulation rate seem to be able to implant a large number of embryos; it is during the early fetal growth when most prenatal mortality occurs (Bradford 1969 in mice; Freking et al., 2007 in pigs; Chapter 4 of this Thesis in rabbits). This mortality could be due to a higher 
proportion of immature oocytes, a greater embryonic diversity or a higher embryonic or fetal competence for uterine resources. Further research is needed to know whether the increased fetal mortality is due to one or more of these causes.

\section{Other selection possibilities}

The experiments of selection for ovulation rate in prolific multiparous species have been inefficient increasing litter size. Prenatal survival, the other component of litter size, has a moderately low heritability and it is positively correlated with litter size. If selection was performed on prenatal survival, the theoretical correlated response in litter size, estimated with the parameters of Chapter 3 and 4 of this Thesis, would be around 0.35 kits per generation. A similar response would be obtained if selection was for fetal survival. However, the negative genetic correlation of fetal and prenatal survival with ovulation rate could cause lower than expected responses.

There are two experiments of selection for prenatal survival, one in mice (Bradford, 1969) and the other one in pig (Rosendo et al., 2007). In these experiments, selection has been effective increasing litter size compared to a control line. However, the criterion of selection was prenatal survival corrected for number of fetuses (in mice) or for ovulation rate (in pigs) to reduce the effect of selection against ovulation rate. This criterion is closer to selection for an index with no optimal economical weights than to selection for a single component. Besides, the experiments of selection for uterine capacity as a measure of prenatal survival have not been efficient increasing litter size. Therefore, selection for an index of ovulation rate and prenatal survival optimally weighting each component could be more efficient in increasing litter size than selection only for fetal or prenatal survival.

Several authors predicted greater response in litter size from selection for an index of its components than from direct selection for litter size in swine (Johnson et al., 1984; Bennett and Leymaster, 1989), rabbits (Blasco et al., 1993b) and mice (Clutter et al., 1990; Ribeiro et al., 1997a,b). Two experiments of index selection were developed in prolific species (Clutter et al., 1990 in mice; Johnson et al., 1999 in pigs). In these experiments, response was lower than expected. The reason for the lower than expected responses is probably the construction of the index using genetic correlations 
estimated with low accuracy (Falconer and Mackay, 2001), which is usually a problem in this kind of experiments.

An alternative to selection for an index could be two-step selection, which would be less affected by the accuracy of the genetic correlations. There is an experiment of two-step selection, performed in pigs (Ruíz-Flores and Johnson, 2001). In this experiment, response in litter size was approximately twice the response observed in experiments of selection for litter size in pigs. In rabbits, an experiment of two-step selection for ovulation rate and litter size is currently being performed. Results have not been published yet, but preliminary analyses seem to be encouraging.

\section{Literature cited}

Argente, M. J., A. Blasco, J. A. Ortega, C. S. Haley, and P. M. Visscher. 2003. Analyses for the presence of a major gene affecting uterine capacity in unilaterally ovariectomized rabbits. Genetics 163:1061-1068.

Al-Shorepy, S. A., A. C. Clutter, R. M. Blair, and M. K. Nielsen. 1992. Effects of three methods of selection for litter size in mice on pre-implantation embryonic development. Biol. Reprod. 46:958-963.

Blasco, A., J. P. Bidanel, G. Bolet, C. Haley, and M. A. Santacreu. 1993a. The genetics of prenatal survival of pigs and rabbits, a review. Livest. Prod. Sci. 37:1-21.

Blasco, A., M. A. Santacreu, R. Thompson, and C. Haley. 1993b. Estimates of genetic parameters for ovulation rate, prenatal survival and litter size in rabbits from an elliptical selection experiment. Livest. Prod. Sci. 34:163-174.

Bakker, H., J. H. Wallinga, and R. D. Politiek. 1978. Reproduction and body weight of mice after long-term selection for large litter size. J. Anim. Sci. 46:1572-1580.

Bennett, G. L., and K. A. Leymaster. 1989. Integration of ovulation rate, potential embryonic viability and uterine capacity into a model of litter size in swine. J. Anim. Sci. 67:1230-1241. 
Bolet, G., L. Ollivier, and P. Dando. 1989. Sélection sur la prolificité chez le porc. I. Résultats d'une expérience de sélection sur onze générations. Genet. Sel. Evol. 21:93-106.

Bradford, G. E. 1969. Genetic control of ovulation rate and embryo survival in mice. I. Response to selection. Genetics 61:907-918.

Brun, J. M., G. Bolet, and J. Ouhayoun. 1992. The effects of crossbreeding and selection on productive and reproductive traits in a triallel experiment between three strains of rabbits. J. Appl. Rabbit Res. 15:181-189.

Cunningham, P. J., M. E. England, L. D. Young, and D. R. Zimmerman. 1979. Selection for ovulation rate in swine: Correlated response in litter size and weight. J. Anim. Sci. 48:509-516.

Clutter, A. C., M. K. Nielsen, and R. K. Johnson. 1990. Alternative methods of selection for litter size in mice: I. Characterization of base population and development of methods. J. Anim. Sci. 68:3536-3542.

Falconer, D. S. 1963. Qualitatively different responses to selection in opposite directions. In: Statistical genetics and plant breeding. NAS-NRC Publ. 982:487490.

Falconer, D. S., and T. F. C. Mackay. 2001. Caracteres correlacionados. In: Introducción a la genética cuantitativa. Ed. Acribia S.A. Zaragoza, Spain. Pages 317-339.

Freking, B. A., K. A. Leymaster, J. L. Vallet, and R. K. Christenson. 2007. Number of fetuses and conceptus growth throughout gestation in lines of pigs selected for ovulation rate or uterine capacity. J. Anim. Sci. 85:2093-2103.

García, M. L., and M. Baselga. 2002. Estimation of genetic response to selection in litter size of rabbits using a cryopreserved control population. Livest. Prod. Sci. 74:4553.

Geisert, R. D., and R. A. M. Schmitt. 2002. Early embryonic survival in the pig: Can it be improved? J. Anim. Sci. 80(E-Suppl.): E54-E65. 
Gion, J. M., A. C. Clutter, and M. K. Nielsen. 1990. Alternative methods of selection for litter size in mice: II. Response to thirteen generations of selection. J. Anim. Sci. 68:3543-3556.

Haley, C. S., and G. J. Lee. 1992. Genetic factors contributing to variation in litter size in British Large White gilts. Livest. Prod. Sci. 30:99-113.

Johnson, R. K., D. R. Zimmerman, and R. J. Kittok. 1984. Selection for components of reproduction in swine. Livest. Prod. Sci. 11:541-558.

Johnson, R. K., M. K. Nielsen, and D. S. Casey. 1999. Responses in ovulation rate, embryonal survival and litter traits in swine to 14 generations of selection to increase litter size. J. Anim. Sci. 77:541-557.

Krisher, R. L. 2004. The effect of oocyte quality on development. J. Anim. Sci. 82 (E. Suppl.): E14-E23.

Koenig, J. L. F., D. R. Zimmerman, F. E. Eldrige, and J. D. Kopf. 1986. The effect of superovulation and selection for high ovulation rate on chromosomal abnormalities in swine ova. J. Anim. Sci. 63(Suppl.1):202 (Abstr.).

Land, R. B., and D. S. Falconer. 1969. Genetic studies of ovulation rate in the mouse. Genet. Res. 13:25-46.

Leymaster, K. A., and R. K. Christenson. 2000. Direct and correlated responses to selection for ovulation rate or uterine capacity in swine. J. Anim. Sci. 78(Suppl. 1):68. (Abstr.)

Leiser, R., and P. Kaufmann. 1994. Placental structure: in a comparative aspect. Experimental and Clinical Endocrinology 102:122-134.

Mocé, M. L., M. A. Santacreu, A. Climent, and A. Blasco. 2004. The effect of divergent selection for uterine capacity on prenatal survival in rabbits: Maternal and embryonic genetic effects. J. Anim. Sci. 82:68-73.

Pope, W. F. 1988. Uterine Asynchrony: A cause of embryonic loss. Biol. Reprod. 39:999-1003.

Ribeiro, E. L. de A., M. K. Nielsen, G. L. Bennett, and K. A. Leymaster. 1997a. A simulation model including ovulation rate, potential embryonic viability, and 
uterine capacity to explain litter size in mice: I. Model development and implementation. J. Anim. Sci. 75:641-651.

Ribeiro, E. L. de A., M. K. Nielsen, K. A. Leymaster, and G. L. Bennett. 1997b. A simulation model including ovulation rate, potential embryonic viability, and uterine capacity to explain litter size in mice: II. Responses to alternative criteria of selection. J. Anim. Sci. 75:652-656.

Rosendo, A., T. Druet, J. Gogué, and J. P. Bidanel. 2007. Direct responses to six generations of selection for ovulation rate or prenatal survival in Large White pigs. J. Anim. Sci. 85:356-364.

Ruíz-Flores, A., and R. K. Johnson. 2001. Direct and correlated responses to two-stage selection for ovulation rate and number of fully formed pigs at birth in swine. J. Anim. Sci. 79:2286-2297.

Santacreu, M. A. 2006. La supervivencia prenatal en la coneja reproductora. XXXI Symposium de cunicultura de ASESCU, Lorca, Murcia, Spain. Vol. I:229-236.

Torres, S., F. Hulot, and M. Meunier. 1984. Étude comparée du développement et de la mortalité embryonnaire chez deux genotypes de lapines. 3rd World Rabbit Congress. Rome-Italy, Vol. 2:417-425.

Torres, S., F. Hulot, M. Meunier, and C. Sevellec. 1987. Comparative study of preimplantation development and embryonic loss in two rabbit strains. Reprod. Nutr. Dévelop. 27(3):707-714.

Wilde, M. H., S. Xie, M. L. Day, and W. F. Pope. 1988. Survival of small and large littermate blastocysts in swine after synchronous and asynchronous transfer procedures. Theriogenology 30:1069-1074.

Wilmut I., D. I. Sales, and C. J. Ashworth. 1986. Maternal and embryonic factors associated with prenatal loss in mammals. J. Reprod. Fert. 76:851-864.

Wintenberger-Torres, S. 1974. Relation entre la taille des blastocystes de lapine a l'implantation et la survie embryonnaire. Ann. Biol. Anim. Bioch. Biophys., $14(I): 41-52$.

Xie, S., D. M. Broermann, K. P. Nephew, R. D. Geisert, and W. F. Pope. 1990. Ovulation and early embryogenesis in swine. Biol. Reprod. 43:236-240. 


\title{
Chapter 7
}

\section{Conclusions}

\author{
P. Laborda
}

Instituto de Ciencia y Tecnología Animal, Universidad Politécnica de Valencia, 46071 Valencia. Spain. 

1. The heritability of ovulation rate was moderately low (0.16). The heritability of litter size was low (0.09). The heritabilities of embryonic, fetal and prenatal survival were low to moderate $(0.09,0.24$ and 0.14 , respectively).

2. The phenotypic correlation between ovulation rate and litter size was 0.09 . The phenotypic correlations of ovulation rate with embryonic, fetal and prenatal survival were $-0.07,-0.26$ and -0.28 , respectively.

3. Selection for ovulation rate increased ovulation rate in 1.3 ova (genetic trends) to 2.1 ova (control line) in 10 generations.

4. In spite of initial expectations, there was no correlated response in litter size, indicating that the genetic correlation should be near zero. Therefore, selecting for $O R$ in rabbit populations with the aim to increase litter size cannot be recommended.

5. The estimated genetic correlation between ovulation rate and embryonic survival had a probability of $95 \%$ of being in the interval from -0.57 to 0.64 . However, the response obtained in embryonic survival indicates that the genetic correlation should be low or close to zero. Embryonic survival decreased slightly with selection when it was estimated as the difference between the selected and the control lines (5\% in 10 generations), but the genetic trends did not show any change.

6. The estimated genetic correlations of ovulation rate with fetal and prenatal survival were negative (probability of being negative 1.00 and 0.98 , respectively). Prenatal survival decreased with selection. This decrease was basically due to the fetal component ( $8 \%$ and $12 \%$ in 10 generations estimated with genetic trends and with control population, respectively). 
7. The correlated responses to selection in the ovulatory and implantatory differences did not have a clear pattern: genetic trends showed small increases with selection, which were not confirmed with the control line. The ovulatory and implantatory differences seem to be highly variable traits, and it has not been possible to determine if an increase in these traits were responsible for the increased fetal mortality with selection. 

